\title{
Mullite-Based Ceramics from Mining Waste: A Review
}

\author{
Maximina Romero ${ }^{1, *(\mathbb{D}}$, Isabel Padilla ${ }^{1}$, Manuel Contreras ${ }^{2}$ and Aurora López-Delgado ${ }^{3} \mathbb{D}$ \\ 1 MEDES-IETcc Group, Eduardo Torroja Institute for Construction Science, IETcc-CSIC, Serrano Galvache 4, \\ 28033 Madrid, Spain; isabel.padilla@ietcc.csic.es \\ 2 Department of Integrated Sciences, Research Centre for Natural Resources, Health and \\ Environment (RENSMA), El Carmen Campus, University of Huelva, 21007 Huelva, Spain; \\ manuel.contreras@dfa.uhu.es \\ 3 MEDES-CENIM Group, National Centre for Metallurgical Research, CENIM-CSIC, Av. Gregorio del Amo 8, \\ 28040 Madrid, Spain; alopezdelgado@cenim.csic.es \\ * Correspondence: mromero@ietcc.csic.es
}

check for updates

Citation: Romero, M.; Padilla, I.; Contreras, M.; López-Delgado, A. Mullite-Based Ceramics from Mining Waste: A Review. Minerals 2021, 11, 332. https://doi.org/10.3390/ $\min 11030332$

Academic Editor: Alexander Mikhailovich Kalinkin

Received: 19 February 2021

Accepted: 18 March 2021

Published: 23 March 2021

Publisher's Note: MDPI stays neutral with regard to jurisdictional claims in published maps and institutional affiliations.

Copyright: (c) 2021 by the authors. Licensee MDPI, Basel, Switzerland. This article is an open access article distributed under the terms and conditions of the Creative Commons Attribution (CC BY) license (https:// creativecommons.org/licenses/by/ $4.0 /)$.

\begin{abstract}
Mullite $\left(3 \mathrm{Al}_{2} \mathrm{O}_{3} \cdot 2 \mathrm{SiO}_{2}\right)$ is an aluminosilicate characterized by excellent physical properties, which makes it an important ceramic material. In this way, ceramics based on mullite find applications in different technological fields as refractory material (metallurgy, glass, ceramics, etc.), matrix in composite materials for high temperature applications, substrate in multilayer packaging, protective coatings, components of turbine engines, windows transparent to infrared radiation, etc. However, mullite is scarce in nature so it has to be manufactured through different synthesis methods, such as sintering, melting-crystallization or through a sol-gel route. Commonly, mullite is fabricated from pure technical grade raw materials, making the manufacturing process expensive. An alternative to lowering the cost is the use of mining waste as silica $\left(\mathrm{SiO}_{2}\right)$ and alumina $\left(\mathrm{Al}_{2} \mathrm{O}_{3}\right)$ feedstock, which are the necessary chemical compounds required to manufacture mullite ceramics. In addition to the economic benefits, the use of mining waste brings out environmental benefits as it prevents the over-exploitation of natural resources and reduces the volume of mining waste that needs to be managed. This article reviews the scientific studies carried out in order to use waste (steriles and tailings) generated in mining activities for the manufacture of clay-based ceramic materials containing mullite as a main crystalline phase.
\end{abstract}

Keywords: mullite; clay-based ceramics; mining waste; sterile; tailings; iron and aluminum waste; boron; molybdenum and lithium waste; coal gangue; kaolin waste; ornamental rock waste

\section{Introduction}

Nowadays, mining is a critical industry for global economic and social development, and it will continue to be the main resources provider in the immediate future [1]. However, just as there have been great technological advances in mining techniques that allow a larger recovery of minerals and therefore a continuous growth of world production, the impoverishment of deposits in terms of the grade, which requires larger scale, more complex and depth excavations, has an even higher impact on a major generation of waste. Figure 1 shows the evolution of world production of minerals in the 2009-2018 decade [2], and Figure 2 shows global production, in the last years, of different metals or minerals reported in this paper, which include: iron [3], aluminum [4], boron [5], molybdenum [6], lithium [7], coal [8] and kaolin [9], among others. 


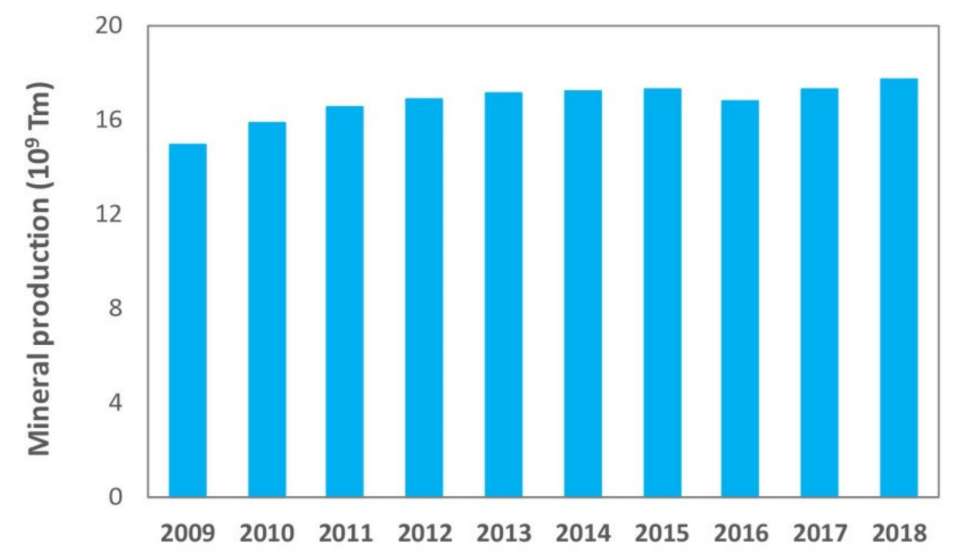

Figure 1. Evolution of world mineral production [2].
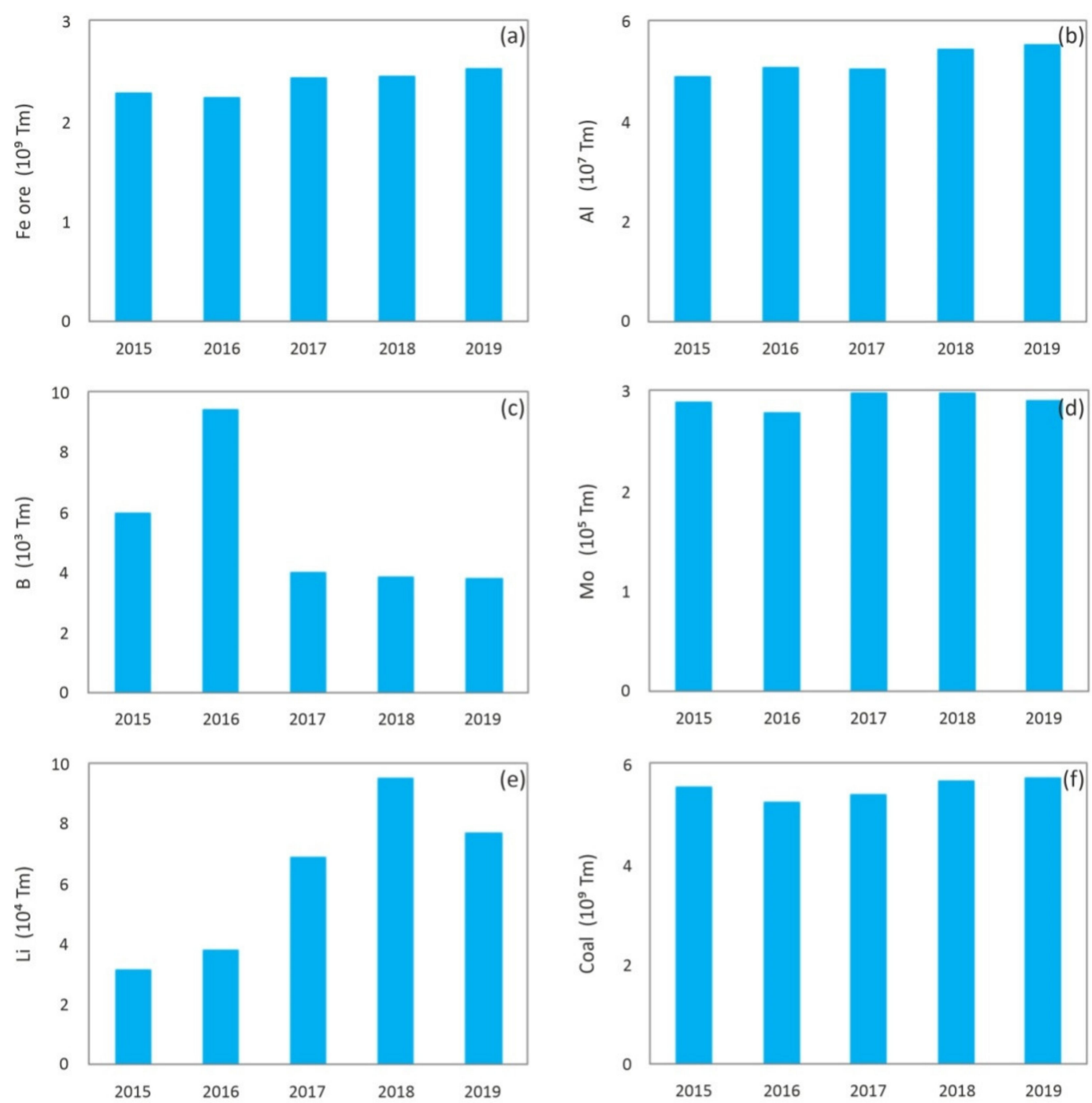

Figure 2. Cont. 


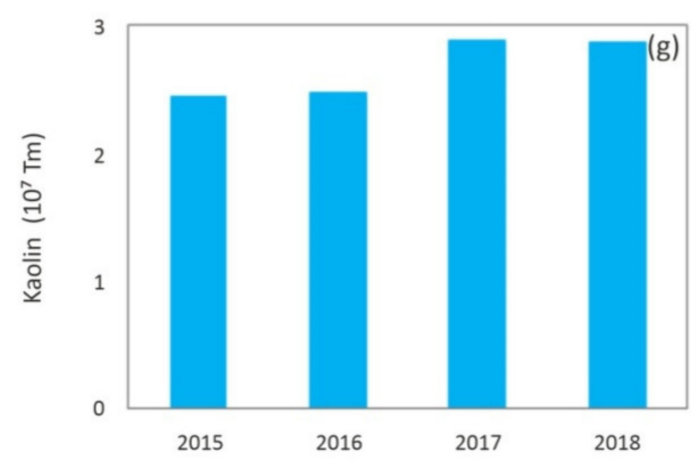

Figure 2. Worldwide production of: (a) Iron ore mineral [3]; (b) Countries with the largest smelter production of aluminum [4]; (c) Boron [5]; (d) Molybdenum [6]; (e) Lithium [7]; (f) Coal [8]; (g) Kaolin [9].

Thus, mining activities imply the generation of huge amounts of mining waste that produce great impacts on the environment, among others instability in waste dumps, acid drainage mainly due to oxidation processes, water pollution, air pollution and a long etcetera, which also includes the huge extents of territory occupied by the deposits of residues from the mineral washing and flotation plants [10,11].

Worldwide, there are approximately 3500 solid mining waste facilities, with an estimated generation of over 100 billion tons per year [12]. An idea of the magnitude of waste generated is given by the fact that, for example, in the case of iron or aluminum mining, the amount of solid waste generated is several times greater than the mass of the metals extracted, but in the case of noble metals such as gold, this ratio is greater than millions of times $[13,14]$.

Tayebi-Khorami et al. [12] in an interesting study on the current management frameworks of mining waste, established the need for the mining industry to develop strategies in the medium and short term for proper management and use of waste aimed at achieving a lower environmental impact. The design and implementation of robust long-term solutions remains, to date, a challenge for the mining industry, due to the specificity of the sites where wastes are generated, the local weather conditions and the physicochemical heterogeneity of their wastes [15]. Besides, the global megatrends (large, social, economic, political, environmental, or technological changes) as driving technology demands should be taking into consideration by the mining industry for its future economic growth [16].

Solid mining waste is grouped into two main groups, viz mine waste rock (steriles) and tailings. Mine waste rock consists of low-grade excavated bedrock that has been transported to access profitable ore, and generally comprises of relatively coarse broken granular rock in the size range from sand to pebbles or boulders. They are mainly piled on high mounds which are porous, hydraulically unsaturated, and therefore highly exposed to atmospheric conditions (oxidation). Tailings are the main waste, both in volume and weight, generated in the process of concentrating minerals. Tailings are composed of process water and fines remaining after crushing and beneficiation of the ore, which may contain secondary materials from reactions with processing reagents, such as explosive agents or extraction chemicals [17]. Tailings streams are pumped into tailings storage facilities, TSFs (pools or dams) where they are deposited with low atmospheric exposure, which can even originate reducing conditions. Tailings can also be dried and stacked with the consequent displacement of the fines by the wind over long distances. The volume of tailings generated in the extraction of ore is almost equal to the volume of ore processed. It is estimated that there are approximately 1900 controlled TSFs worldwide in which $56 \times 10^{9} \mathrm{~m}^{3}$ of mine tailings are stored. This volume is expected to increase up to $69 \times 10^{9} \mathrm{~m}^{3}$ by 2025 [18]. The high volume of tailings stored at TSF gives rise to significant environmental problems resulting from the occupancy of large areas of land, including farmland and forests, and the consequent destruction of the landscape [19].

Moreover, tailings disposal also involves serious impacts on human health. In dry seasons, water from the surface of the tailings dams evaporates, leaving a fine, powdery 
material on the surface that pollutes the air in the surrounding areas. On the other hand, in rainy seasons, tailings deposits can collapse, causing landslides, with the consequent risk for the inhabitants of neighboring towns [20]. Over the past 40 years, numerous tailings dam collapses have occurred, resulting in significant impacts such as a prolonged suspension of mining activity, environmental degradation, damage to the image of the mining company, economic implications for the industry, legal implications and loss of human life [21]. Figure 3 shows shocking images of the collapse of several tailings dams.
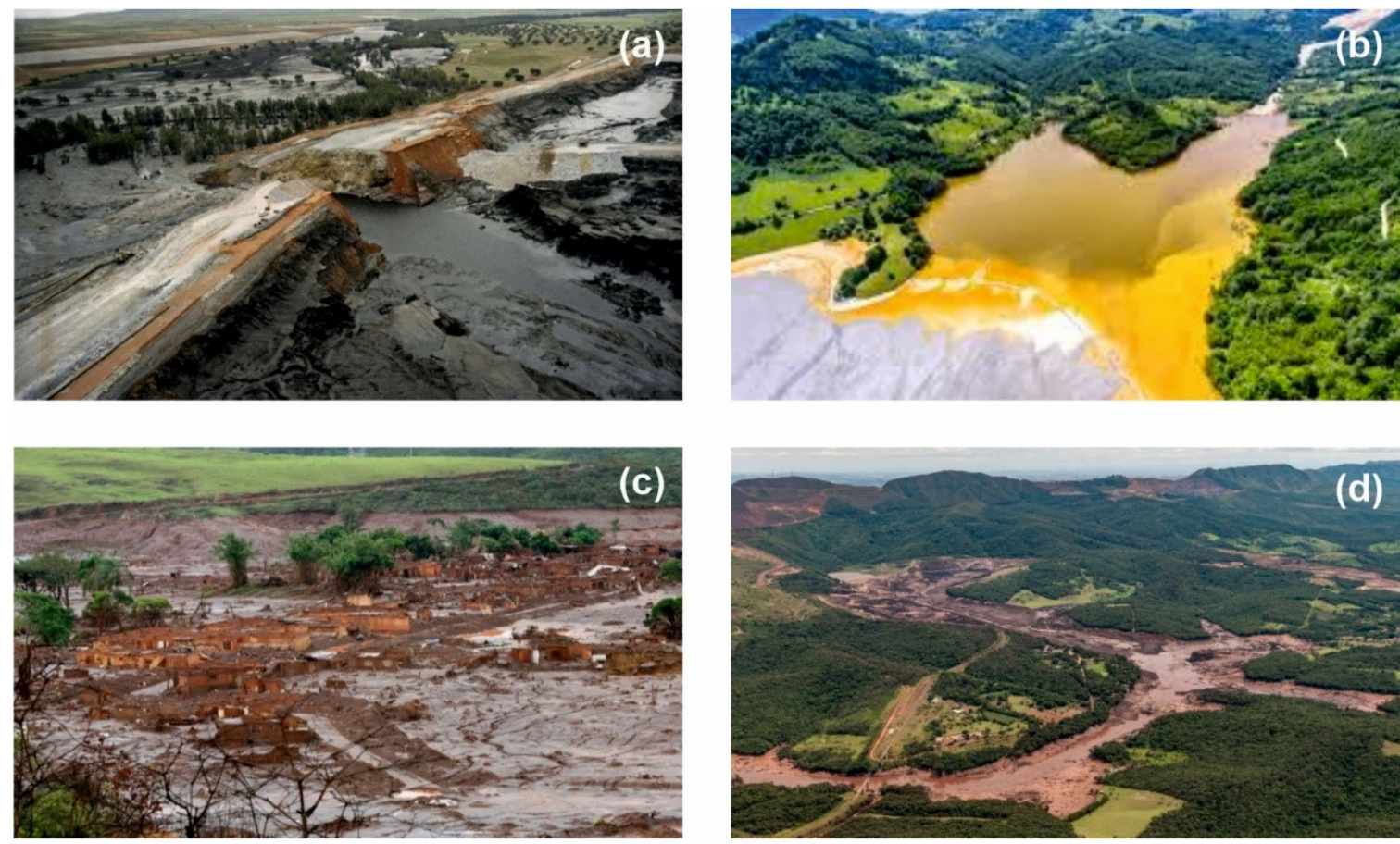

Figure 3. Images of several environmental disasters produced by collapse of tailing dams: (a) collapse of tailings dam in Aználcollar, Spain, 1998 [22]; (b) Baia Mare disaster, Romania, 2000 [23]; (c) Mariana dam disaster, Brazil, 2015 [24]; (d) Brumadinho dam disaster, Brazil, 2019 [25].

Definitive solutions to the problem of mining waste are still far from being reached and much research and technological development must continue to be carried out. Although both types of waste present different geochemical behaviors, due to the large granulometric differences between them, different physical-chemical characteristics, and above all to the different storage practices, they can be considered, a priori, as a source of new exploitable materials [26].

In recent years, different studies have been carried out with the objective of recovering mining waste through their incorporation into different materials. Thus, nanostructured $\mathrm{Mg}$ (II)Al(III) layered double hydroxide (LDH) was manufactured from waste serpentine tailings by a chemical precipitation method [27]. Hexagonally ordered mesoporous silica materials were prepared from iron tailings by an innovative non-hydrothermal process at room temperature. These materials can be applied to energy storage or environmental protection [28]. Several studies have reported on the valorization of mining waste in building materials. In this way, iron ore waste was used as a complementary cementitious material to prepare colored composite cements more resistant to acid attack than Portland cement [29]; gold ore tailings were used as siliceous raw material for cement production [30]. For this application, the cementitious/pozzolanic properties of mineral tailings can be improved by activation methods [31]; molybdenum tailings have been investigated as replacement of fine aggregates in structural concrete [32]; and copper tailings were evaluated as raw material for geopolymer manufacture. Fluorite mines waste has been incorporated in the raw material mixture for the manufacture of glass [33], which allows for the incorporation 
of the potentially toxic elements of the tailings into the glass structure [34]. The valuation of mining waste as fillers has also been considered in some studies. For instance, lead-zinc mill waste was studied as paste backfilling for an underground metalliferous mine [35]; and perlite wastes was used for the manufacture of lightweight materials by combining the geopolymerization technology with the foaming process [36]. A further recovery route investigated for these wastes is the production of synthetic stone. Thus, an artificial arenite was developed from different particle size fractions of the sandstone industry waste mixed with an unsaturated polyester resin [37]. Finally, as one of the potential recovery options, the manufacture of ceramic materials has been satisfactorily evaluated [38-40].The studies conducted to incorporate mine tailings into mullite-based ceramic materials are described hereafter.

Under the conventional model of the linear economy, taking into account the lowering of the ore grade and consequently higher excavation rates, the problem of mining waste and its associated inherent risks would continue to aggravate. In contrast, a circular economy articulates the importance of closed-loop systems that reduce the need for extraction and processing of new resources. As such, within mining activities and following the 3Rs principle of waste reduction (reduces, reuse, recycle), it can make an important contribution [41]. Thus, within the framework of the circular economy (which requires design for repair, reuse, recovery, refurbishment, restoration, and recycling) and the sustainable development objectives (ODS), many mining wastes could be considered, among others, as alternative materials in the construction sector instead of sources of pollution and risk. This solution will lead to the conservation of finite natural resources extensively used in the field of construction and to reduce the environmental impacts related to them $[10,16,42,43]$. Among construction materials, ceramic materials and, specifically those based on mullite, have been established as an appropriate alternative for the recovery of solid mining waste. The use of mining waste in the production of mullite-based ceramics contributes to various sustainable development objectives (ODS) of Agenda 2030, an action plan that resulted from the commitment of the member states of the United Nations, whose main objective is to ensure the protection of people, the planet and prosperity [44]. Thus, as far as objective 7 (affordable and clean energy) is concerned, the use of mining waste as a substitute for pure raw materials allows for a reduction in energy consumption. With regard to objective 13 (climate action), the recovery of waste contributes significantly to the reduction of $\mathrm{CO}_{2}$ and other greenhouse gas emissions. Furthermore, the appropriate management and use of waste avoids negative impacts on terrestrial ecosystems, which are covered by objective 15 (life on land). But undoubtedly, the valorization of mining waste is closely linked to objective 12 (responsible consumption and production), which includes the achievement of a sustainable management and efficient use of natural resources by 2030, while considerably reducing waste generation through prevention, reduction, recycling and reuse activities.

According to the Mindat database [45], mullite (The name and chemical composition of the minerals and crystalline phases mentioned in this review are showed in Appendix A) is a nesosilicate, a group of silicates characterized by un-polymerized $\mathrm{SiO}_{4}$ tetrahedrons, linked to one another by ionic bonds through interstitial cations. The chemical formula is $\mathrm{Al}(4+2 \mathrm{x}) \mathrm{Si}(2-2 \mathrm{x}) \mathrm{O}(10-\mathrm{x})$ where $\mathrm{x}=0.17-0.59$, and is composed of $38.00 \mathrm{wt} . \%$ aluminum, $13.18 \mathrm{wt} . \%$ silicon, and $48.82 \mathrm{wt} . \%$ oxygen, with the empiric formula $\mathrm{Al}_{4.5} \mathrm{Si}_{1.5} \mathrm{O}_{9.75}$. Figure 4 shows the structure of mullite [46]. The mullite etymology is related to the place where it was found the first time in 1924, the Isle of Mull, Scotland, UK. Mullite is a crystalline phase of great technological importance due to its excellent technical properties, such as: low expansion and thermal conductivity $\left(\sim 4.5 \times 10^{-6}{ }^{\circ} \mathrm{C}^{-1}\right.$ and $6 \mathrm{kcal} \cdot \mathrm{m}^{-1} \cdot \mathrm{h}^{-1}{ }^{\circ} \mathrm{C}^{-1}$ at $20^{\circ} \mathrm{C}$, respectively), and appropriate fracture strength and toughness ( $\sim 200 \mathrm{MPa} \mathrm{y} \sim 2.5 \mathrm{MPa} \mathrm{m}^{1 / 2}$, respectively) [47]. In addition, it features high creep resistance, corrosion stability and thermal stability. All these features currently make mullite to be, probably, one of the most important phases in traditional and advanced ceramic. Monolithic mullite ceramics find application in tableware [48], porcelain stoneware [49,50], refractory [51] or electronic devices [52]. Mullite coatings have been used successfully as 
environmental barrier coatings for the protection against oxidizing agents, reducing agents or aggressive chemicals at high temperatures [53,54]. Besides ceramic or metallic surfaces, mullite composites, including composites prepared with mullite matrix or mullite fiber, find important applications as components in turbine engines, high-performance furnaces or heat shields for space vehicles [55-57].

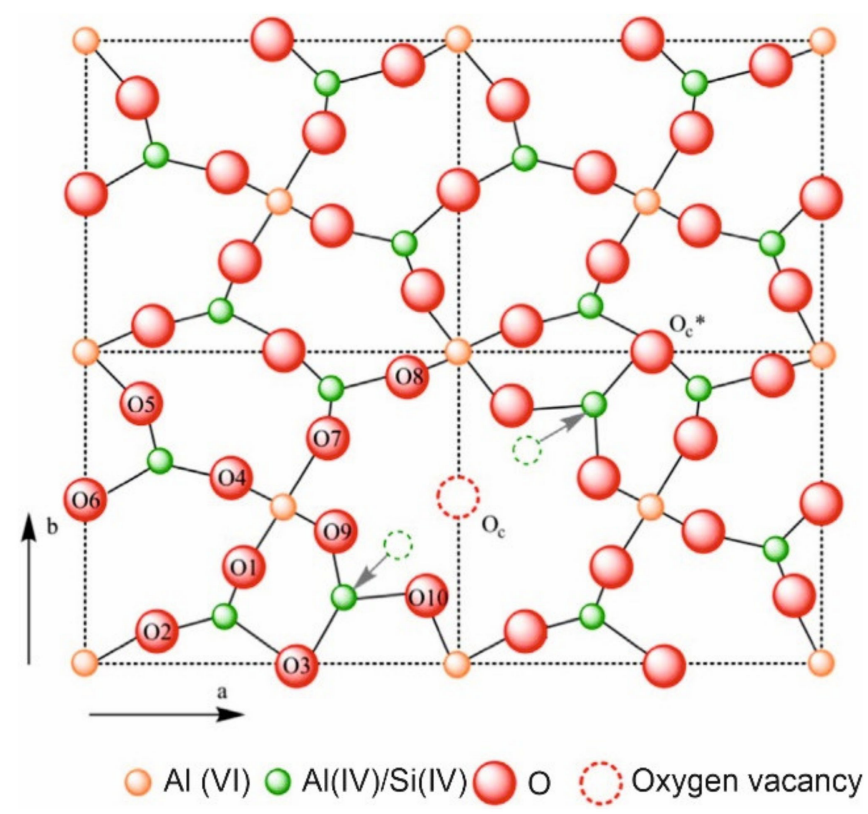

Figure 4. Crystal structure of mullite along c-axis [46].

Mullite is a mineral not very abundant in nature since high temperature and low pressure conditions are required for its formation. Due to its high technological demand, mullite has to be manufactured by synthetic methods, rather than being mined. For the synthesis of mullite, there are three basic routes, namely: sintering, melting and chemical processing [58].

- $\quad$ Sinter-mullite. Through sintering processing, mullite is basically obtained by reactions in the solid state by interdiffusion of aluminum, silicon and oxygen atoms. The aluminum-bearing raw materials used for the synthesis of mullite are mainly clay minerals, basically kaolinite $\left(\mathrm{Al}_{2} \mathrm{Si}_{2} \mathrm{O}_{5}(\mathrm{OH})_{4}\right)$ and pirofilite $\left(4 \mathrm{SiO}_{2} \cdot \mathrm{Al}_{2} \mathrm{O}_{3} \cdot \mathrm{H}_{2} \mathrm{O}\right)$; other minerals such as $\mathrm{Al}_{2} \mathrm{SiO}_{5}$ (sillimanite, cianite and andalusite); $\mathrm{AlO}(\mathrm{OH})$ (boehmite and diaspore); gibbsite $\left(\mathrm{Al}(\mathrm{OH})_{3}\right)$ and bauxite $\left(\left(\mathrm{AlO}_{\mathrm{x}}(\mathrm{OH})_{3-2 \mathrm{x}}\right)\right.$ with $\left.\mathrm{x}=0-1\right)$ are usually added as supplementary raw materials. Quartz $\left(\mathrm{SiO}_{2}\right)$ is used as Si source. During sintering at $\sim 500{ }^{\circ} \mathrm{C}$, kaolinite is transformed into metakaolinite $\left(\mathrm{Al}_{2} \mathrm{Si}_{2} \mathrm{O}_{7}\right)$ by the loss of structural molecules of water. Later, at higher temperature $\left(\sim 980^{\circ} \mathrm{C}\right)$ metakaolinite is decomposed in $\mathrm{Si}-\mathrm{Al}$ spinel and amorphous silica. The reaction between these two phases at $1200{ }^{\circ} \mathrm{C}$ origins the formation of mullite [50]. For the complete transformation of kaolinite into mullite by the sintering process, very high temperatures are required $\left(1600-1700{ }^{\circ} \mathrm{C}\right)$ due to the diffusion coefficient of mullite in the grain border being very low. To reduce the mullitization temperature, it is convenient to use systems to mix raw materials at the atomic level.

- Fused-mullite. Mullite is synthesized by fusing of raw materials (alumina Bayer, quartz sand, rock crystal and fused silica) in an electric furnace at a temperature over $2000{ }^{\circ} \mathrm{C}$ until homogeneous molten is achieved. By controlled crystallization during the cooling, molten mullite is developed [59].

- Chemical-mullite. This method comprises the use of different chemical processes such as sol-gel technologies [60], precipitation [61], hydrolysis [62], pyrolysis [63] or cool vapor deposition techniques (CVD) [64]. 
Accordingly, the synthesis of mullite is an expensive process due to the requirement of high temperature or complex synthesis methods. On the other hand, the kaolin world reserves are drastically decreasing, because their demand for the production of paper and ceramic building materials (principally ceramic tiles). For both reasons, during the two last decades, research efforts have been conducted to study the synthesis of mullite from less common and low cost raw materials such as inorganic waste from different sources and characteristics. Thus, waste from the agro-food industry (rice husk ash) [65,66], spent cracking catalysts [67-69], aluminum buffing dust [70], aluminum sludge generated in water treatment plants [71], ceramic wastes from the manufacture of ceramic tiles [72] or fly ash $[73,74]$, among others have been investigated as raw materials for the synthesis of mullite.

Furthermore, the valorization of mining waste by the production of mullite-based ceramic materials has also been the object of scientific interest. The aim of this work is to carry out a review of the scientific production performed in recent years on the use of waste rock and tailings from the mining industry in the manufacture of ceramic materials in which mullite is developed as one of the main crystalline phases. In this sense, the review includes mining waste from the extraction of metals (iron, aluminum, boron, molybdenum and lithium) and minerals (coal gangue, kaolin and ornamental rocks).

\section{Mining Waste from the Extraction of Metals}

\subsection{Iron Mining Waste}

Iron is the most frequently used metal in the world. As the main component of steel, it is an essential element in different sectors such as the automobile, construction industry, engineering or equipment production. In 2019, world iron production was approximately $2.5 \times 10^{9}$ metric tons, with Australia and Brazil, with $930 \times 10^{6}$ and $480 \times 10^{6}$ metric tons respectively, being the largest producers [3]. Possible ways of recovering the iron mining waste include its use as catalysts for the synthesis of carbon nanomaterials [75], ceramic additive [76] and its incorporation into cement [29], concrete [77] or geopolymers [78]. The main results of the aimed at the synthesis of mullite-based ceramics from iron mining waste are described hereafter. Tables 1-3 list the chemical composition of the iron waste, the processing parameters and the technological properties of the developed ceramic materials.

Table 1. Chemical composition (expressed wt.\% oxide) of iron mining waste.

\begin{tabular}{|c|c|c|c|c|c|c|c|c|c|c|c|}
\hline Reference & $\mathrm{SiO}_{2}$ & $\mathrm{Al}_{2} \mathrm{O}_{3}$ & $\mathrm{Fe}_{2} \mathrm{O}_{3}$ & $\mathrm{CaO}$ & $\mathrm{MgO}$ & $\mathrm{Na}_{2} \mathrm{O}$ & $\mathrm{K}_{2} \mathrm{O}$ & $\mathrm{TiO}_{2}$ & $\mathrm{P}_{2} \mathrm{O}_{5}$ & $\mathrm{MnO}$ & LOI \\
\hline [79] & $39.40-63.32$ & $1.22-1.42$ & $32.31-55.61$ & $0.08-0.36$ & - & - & - & - & - & - & $2.33-3.42$ \\
\hline [80] & $19.84-21.63$ & $11.91-13.25$ & $66.15-72.21$ & - & $0.71-0.84$ & - & $1.25-1.53$ & - & - & - & nd \\
\hline [81] & 24.4 & 10.95 & 44.52 & 6.2 & 0.99 & 0.28 & 0.86 & 0.42 & 2.78 & - & 6.95 \\
\hline [82] & $15.78-20.45$ & $13.19-18.81$ & $57.32-67.44$ & $0.18-0.34$ & - & - & $0.21-0.28$ & - & $0-0.66$ & $1.49-2.62$ & 7.3-9.4 \\
\hline
\end{tabular}

nd $=$ not determined.

Table 2. Experimental conditions used in the development of mullite-based materials from iron mining waste.

\begin{tabular}{|c|c|c|c|c|}
\hline Reference & Percentage of Use (wt.\%) & Additional Raw Materials (wt.\%) & Shaping Method & Sintering Conditions \\
\hline [79] & $30-50$ & $\begin{array}{c}\text { Clay (35-60) } \\
\text { Fluxing minerals (0-15) }\end{array}$ & $\begin{array}{c}\mathrm{UP} ; 25-30 \mathrm{MPa} \\
\varnothing 50 \mathrm{~mm} \\
110 \times 55 \mathrm{~mm}\end{array}$ & $\begin{array}{l}1060-1200{ }^{\circ} \mathrm{C} \\
10^{\circ} \mathrm{C} / \mathrm{min}\end{array}$ \\
\hline$[80]$ & 60 & Kaolinitic clay (40) & $\begin{array}{c}\mathrm{UP} ; 30 \mathrm{MPa} \\
50 \times 50 \mathrm{~mm} \\
110 \times 55 \mathrm{~mm}\end{array}$ & $\begin{array}{c}850-1000{ }^{\circ} \mathrm{C} \\
1 \mathrm{~h}\end{array}$ \\
\hline [81] & $50-70$ & $\begin{array}{c}\text { Kaolin (25) } \\
\text { Quartz sand (5-25) }\end{array}$ & $\begin{array}{c}\mathrm{UP} ; 20 \mathrm{MPa} \\
60 \times 35 \times 5 \mathrm{~mm}\end{array}$ & $\begin{array}{c}1150-1250^{\circ} \mathrm{C} \\
5^{\circ} \mathrm{C} / \mathrm{min} ; 30 \mathrm{~min}\end{array}$ \\
\hline [82] & 100 & $\mathrm{nr}$ & $\begin{array}{c}\mathrm{UP} ; 10 \mathrm{MPa} \\
50 \times 50 \times 5 \mathrm{~mm}\end{array}$ & $\begin{array}{c}1200{ }^{\circ} \mathrm{C} \\
10^{\circ} \mathrm{C} / \mathrm{min} ; 2 \mathrm{~h}\end{array}$ \\
\hline
\end{tabular}

$\mathrm{UP}=$ uniaxial pressing; $\mathrm{nr}=$ not reported. 
Table 3. Technological properties of mullite-based materials developed from iron mining waste.

\begin{tabular}{|c|c|c|c|c|c|c|}
\hline Reference & Final Material & $\begin{array}{l}\text { Compressive } \\
\text { Strength } \\
\text { (MPa) }\end{array}$ & $\begin{array}{c}\text { Flexural } \\
\text { Strength (MPa) }\end{array}$ & $\begin{array}{c}\text { Water } \\
\text { Absorption (\%) }\end{array}$ & $\begin{array}{l}\text { Apparent } \\
\text { Density } \\
\left(\mathrm{g} / \mathrm{cm}^{3}\right)\end{array}$ & $\begin{array}{c}\text { Firing } \\
\text { Shrinkage (\%) }\end{array}$ \\
\hline [79] & Ceramic tiles & nd & $17-31$ & $<0.5-16.5$ & nd & $0.07-7.00$ \\
\hline [80] & $\begin{array}{l}\text { Ceramic bricks and } \\
\text { pavement blocks }\end{array}$ & $15-70$ & nd & $6-8$ & $2.4-2.7$ & nd \\
\hline [81] & Porcelain tiles & nd & $30-75$ & $<0.5-17$ & nd & $5-16$ \\
\hline [82] & Porcelain tiles & nd & 53.41 & 0.34 & 3.63 & 26.51 \\
\hline
\end{tabular}

nd $=$ not determined.

Das et al. [79] investigated the potential of iron ore tailings as a raw material in the manufacture of ceramic tiles for pavement and flooring. The iron ore tailings were mainly composed of $\mathrm{SiO}_{2}$ and $\mathrm{Fe}_{2} \mathrm{O}_{3}$ along with $\mathrm{Al}_{2} \mathrm{O}_{3}$ as a minority component. From a mineralogical point of view, the main components of iron tailings were hematite $\left(\mathrm{Fe}_{2} \mathrm{O}_{3}\right)$, quartz and kaolinite, while illite $\left(\left(\mathrm{K}, \mathrm{H}_{3} \mathrm{O}\right)(\mathrm{Al}, \mathrm{Mg}, \mathrm{Fe})_{2}(\mathrm{Si}, \mathrm{Al})_{4} \mathrm{O}_{10}\right)$, goethite $(\mathrm{FeO}(\mathrm{OH}))$ and montmorillonite $\left((\mathrm{Na}, \mathrm{Ca})_{0.3}(\mathrm{Al}, \mathrm{Mg})_{2} \mathrm{Si}_{4} \mathrm{O}_{10}(\mathrm{OH})_{2} \cdot \mathrm{nH}_{2} \mathrm{O}\right)$ were identified as minor crystalline phases. The composition containing $40 \mathrm{wt} . \%$ tailings, $50 \mathrm{wt} . \%$ clay and $10 \mathrm{wt} . \%$ flux presented, after firing, a water absorption value lower than $0.5 \%$. The mineralogical composition of the fired tiles was mostly composed of quartz and mullite, with fayalite and anorthite as the minor phases. In terms of its microstructure, it was formed by crystalline phases embedded in a glassy matrix with a homogeneous distribution of pores. All these characteristics enabled these ceramic tiles to be used as glazed tiles suitable for both domestic and industrial floors. In a later study, Gosh et al. [80] informed about the manufacture of ceramic bricks and paving blocks from iron ore tailings. The chemical composition consisted of $\mathrm{SiO}_{2}, \mathrm{Fe}_{2} \mathrm{O}_{3}$ and $\mathrm{Al}_{2} \mathrm{O}_{3}$ as the major oxides and $\mathrm{MgO}$ and $\mathrm{K}_{2} \mathrm{O}$ as the minor components. As concerns the mineralogical composition, the iron ore tailings consisted of magnetite $\left(\mathrm{Fe}^{2+} \mathrm{Fe}^{3+}{ }_{2} \mathrm{O}_{4}, 2.4-6.9\right.$ wt.\%), hematite (0-48.6 wt.\%), goethite (30.1-77.6 wt.\%), kaolinite (13.7-17.3 wt.\%) and quartz (0.7-2.7 wt.\%). The paste composition made up of $60 \mathrm{wt} . \%$ iron tailings and $40 \mathrm{wt} . \%$ kaolinitic clay gave rise after firing to dense materials composed of hematite (72.3-74.1 wt.\%), mullite (2.3-8.4 wt.\%) and quartz (19.3-23.6 wt.\%). The authors pointed out the possibility of manufacturing ceramic bricks and blocks with adequate technological properties at lower temperatures than commercial materials composed of $100 \mathrm{wt} . \%$ of clay, which results in savings in production costs. Chen et al. [81] studied the possibility of manufacturing red porcelain tiles with hematite tailings as a substitute for feldspar $\left(\left(\mathrm{K}, \mathrm{Na}, \mathrm{Ca}, \mathrm{Ba}, \mathrm{NH}_{4}\right)(\mathrm{Si}, \mathrm{Al})_{4} \mathrm{O}_{8}\right)$. The major constituents of the tailings were $\mathrm{Fe}_{2} \mathrm{O}_{3}$, $\mathrm{SiO}_{2}, \mathrm{Al}_{2} \mathrm{O}_{3}$ and $\mathrm{CaO}$, with quartz and hematite being the main crystalline phases; calcite $\left(\mathrm{CaCO}_{3}\right)$ and chlorite $\left(\mathrm{Na}_{0.5} \mathrm{Al}_{4} \mathrm{Mg}_{2} \mathrm{Si}_{7} \mathrm{AlO}_{18}(\mathrm{OH})_{12} \cdot 5 \mathrm{H}_{2} \mathrm{O}\right)$ were also identified as minority phases. The study indicated that the incorporation of tailings promoted the formation of liquid phases and led to a decrease in the sintering temperature of the samples, although it was necessary to optimize their content in the ceramic pastes since an excessive percentage of tailings reduced the densification temperature range. Materials fired at $1200^{\circ} \mathrm{C}$ from the composition consisting of 55-65 wt.\% tailings, $25 \mathrm{wt} . \%$ kaolin and 10-20 wt.\% quartz sand proved to be the most appropriate for obtaining porcelain tiles with suitable technological properties. The fired tiles were made up of quartz, hematite, cristobalite $\left(\mathrm{SiO}_{2}\right)$, mullite and anorthite $\left(\mathrm{CaAl}_{2} \mathrm{Si}_{2} \mathrm{O}_{8}\right)$ and had a dense microstructure with low porosity.

Recently, Fontes et al. [82] reported the use of iron tailings in the manufacture of porcelain tiles. The tailings were separated into three fractions by a dry segregation procedure. In this way, the fractions, namely, iron ore, quartz sand and a fraction collecting the concentrates of the clay minerals, were obtained. The latter presented a series of physical-chemical characteristics that made it more suitable than the original iron tailings for the manufacture of porcelain tiles, without the addition of auxiliary raw materials. Thus, its chemical composition, consisting mainly of $\mathrm{Fe}_{2} \mathrm{O}_{3}, \mathrm{SiO}_{2}$ and $\mathrm{Al}_{2} \mathrm{O}_{3}$ was located in the region of mullite formation in the $\mathrm{SiO}_{2}-\mathrm{Al}_{2} \mathrm{O}_{3}-\mathrm{FeO} / \mathrm{Fe}_{2} \mathrm{O}_{3}$ ternary diagram. The 
incorporation of iron tailings led to the formation of a higher amount of liquid phases during firing. Moreover, it had a smaller particle size, which facilitated the shaping of the pieces (plasticity). The fired tiles were made up of hematite (72.2 wt.\%) together with mullite (17.7 wt.\%), cristobalite (7.1 wt.\%) and an amorphous phase (3.2 wt.\%) and showed a porosity of approximately $5 \%$, with $1.3 \%$ corresponding to open porosity. This low value of porosity was reflected in a water absorption $(0.34 \%)$ that met the requirements for tiles in the group (BIa) (dry pressed tiles with very low water absorption $(<0.5 \%)$. These tiles also showed good mechanical behavior.

\subsection{Aluminum Mining Waste}

Nowadays, over $90 \%$ of the world's aluminum production is achieved by the hydrometallurgical extraction and refining of the alumina contained in bauxite, through the Bayer process [83]. In this process, the bauxite ore, previously ground, is digested at high temperature in a highly caustic solution. At the completion of the digestion, there is a suspension containing an aluminate solution together with sand (material size $>100 \mu \mathrm{m}$ ) and red sludge (fine particles). From this suspension, an aluminum hydrate is separated by precipitation, which is then washed, dried and calcined to yield alumina as the final product of the process. In the Bayer process, a sludge consisting of a mixture of metal oxides is produced as a by-product. This sludge is red in color due to its high iron oxide content. It is estimated that in the production of 1 ton of alumina, 2 tons of red sludge are originated [84]. In 2019, world alumina production was $133 \times 10^{6}$ metric tons, headed by China $\left(73 \times 10^{6}\right.$ metric tons) followed by Australia $\left(20 \times 10^{6}\right.$ metric tons) [85]. Therefore, the amount of red sludge generated in 2019 as a by-product of the Bayer process is estimated to be around $250 \times 10^{6}$ metric tons. In view of the huge production of this waste, numerous studies have investigated its recovery of different applications [86], such as: asphalt binders [87], cement industry [88], geopolymers manufacture [89], ceramic bricks and tiles $[90,91]$ and aluminosilicate glass [92]. Amongst these investigations, those aimed to valorize waste generated in the Bayer process in the production of mullite-based ceramic materials are described hereafter. Tables 4-6 show the chemical composition of Bayer waste, the processing parameters and the technological properties of the developed ceramic materials.

Table 4. Chemical composition (expressed wt.\% oxide) of waste generated in the Bayer process.

\begin{tabular}{ccccccccccc}
\hline Reference & Waste & $\mathbf{S i O}_{\mathbf{2}}$ & $\mathbf{A l}_{\mathbf{2}} \mathbf{O}_{\mathbf{3}}$ & $\mathbf{F e}_{\mathbf{2}} \mathbf{O}_{\mathbf{3}}$ & $\mathbf{C a O}$ & $\mathbf{N a}_{\mathbf{2}} \mathbf{O}$ & $\mathbf{K}_{\mathbf{2}} \mathbf{O}$ & $\mathrm{TiO}_{2}$ & $\mathbf{S O}_{3}$ & $\mathbf{L O I}$ \\
\hline$[93,94]$ & Red mud & 33.57 & 27.66 & 7.56 & 15.26 & 3.54 & 1.76 & 3.36 & - & 7.29 \\
{$[95]$} & Alumina waste & 1.40 & 90.90 & - & - & - & - & - & 7.00 & nd \\
\hline
\end{tabular}

nd $=$ not determined.

Table 5. Experimental conditions used in the development of mullite-based materials from waste generated in the Bayer process.

\begin{tabular}{|c|c|c|c|c|c|}
\hline Reference & Mining Waste & $\begin{array}{c}\text { Percentage of Use } \\
\text { (wt.\%) }\end{array}$ & Additional Raw Materials (wt.\%) & Shaping Method & $\begin{array}{l}\text { Sintering } \\
\text { Conditions }\end{array}$ \\
\hline [93] & Red mud & $65.8-7.0$ & $\begin{array}{l}\text { Kaolin (28.2-30) } \\
\text { Ammonium molybdate (0-6) }\end{array}$ & $\begin{array}{c}\mathrm{UP} ; 25 \mathrm{MPa} \\
\varnothing 25 \mathrm{~mm} \\
70 \times 6 \times 6 \mathrm{~mm}\end{array}$ & $\begin{array}{l}1150-1200{ }^{\circ} \mathrm{C} \\
3^{\circ} \mathrm{C} / \mathrm{min} ; 2 \mathrm{~h}\end{array}$ \\
\hline [94] & Red mud & $23-29$ & $\begin{array}{c}\mathrm{SiC}(35-44) \\
\mathrm{Al}(\mathrm{OH})_{3}(15) \\
\mathrm{V}_{2} \mathrm{O}_{5}(3) \\
\mathrm{AlF}_{3}(4) \\
\text { Graphite (5-20) }\end{array}$ & $\begin{array}{l}\mathrm{UP} ; 20 \mathrm{MPa} \\
35 \times 10 \mathrm{~mm}\end{array}$ & $\begin{array}{l}1150-13500^{\circ} \mathrm{C} \\
2^{\circ} \mathrm{C} / \mathrm{min} ; 3 \mathrm{~h}\end{array}$ \\
\hline [95] & Alumina waste & $48-56$ & Kaolin (44-52) & $\begin{array}{l}\mathrm{UP} ; 33-66 \mathrm{MPa} \\
30 \times 5 \times 5 \mathrm{~mm}\end{array}$ & $\begin{array}{l}1450-1500^{\circ} \mathrm{C} \\
5^{\circ} \mathrm{C} / \mathrm{min} ; 1 \mathrm{~h}\end{array}$ \\
\hline
\end{tabular}

$\mathrm{UP}=$ uniaxial pressing. 
Table 6. Technological properties of mullite-based materials developed from waste generated in the Bayer process.

\begin{tabular}{|c|c|c|c|c|c|c|}
\hline Reference & Mining Waste & Final Material & $\begin{array}{c}\text { Flexural } \\
\text { Strength } \\
(\mathrm{MPa})\end{array}$ & $\begin{array}{c}\text { Water } \\
\text { Absorption } \\
(\%)\end{array}$ & $\begin{array}{c}\text { Apparent } \\
\text { Density } \\
\left(\mathrm{g} / \mathrm{cm}^{3}\right)\end{array}$ & $\begin{array}{c}\text { Firing } \\
\text { Shrinkage } \\
(\%)\end{array}$ \\
\hline [93] & Red mud & Ceramic floor tile & 153-195 & $7-27$ & $1.45-1.83$ & nd \\
\hline [94] & Red mud & $\begin{array}{l}\mathrm{SiC} / \text { mullite composite } \\
\text { porous ceramics }\end{array}$ & $8-68$ & nd & nd & nd \\
\hline [95] & Alumina waste & Porous mullite blocks & $46-56$ & $17-18$ & nd & $10-11$ \\
\hline
\end{tabular}

nd $=$ not determined

Wang et al. [93] studied the manufacture of low-cost pavement tiles from red sludge with additions of kaolin and ammonium molybdate $\left(\left(\mathrm{NH}_{4}\right)_{6} \mathrm{Mo}_{7} \mathrm{O}_{24}\right)$. The results revealed that ammonium molybdate acted as a catalyst for the formation of mullite crystals, promoting sintering at lower temperatures while increasing the rate and degree of reaction. The microstructure of the samples sintered at $1180{ }^{\circ} \mathrm{C}$ was comprised of anisotropic mullite crystals, approximately $10 \mathrm{~mm}$ in length, together with some anorthite crystals. These materials showed a high flexural strength (195 MPa) attributed to the higher fracture energy absorption by the mullite interlocked crystals. Those ones sintered at temperatures higher than $1180{ }^{\circ} \mathrm{C}$ presented a significant decrease in technological properties as a result of the increase in the amount of the glassy phase and the existence of intercrystalline pores. The authors pointed out that the use of ammonium molybdate as a catalyst promoted the formation of fine $\mathrm{Al}_{2} \mathrm{O}_{3}$ crystals with high chemical reactivity. In turn, it generated $\mathrm{MoO}_{3}$, which reduced the viscosity of the silica-rich liquid phase. Therefore, the dissolution of $\mathrm{Al}_{2} \mathrm{O}_{3}$ in the liquid phase was favored and consequently, the nucleation of mullite crystals. In a later study, the authors investigated the use of this same residue as a starting material for the synthesis of $\mathrm{SiC} /$ mullite composite porous ceramics [94]. For this, they used aluminum hydroxide $\left(\mathrm{Al}(\mathrm{OH})_{3}\right)$, Bayer red sludge and silicon carbide $(\mathrm{SiC})$ as raw materials and studied the effect of $\mathrm{V}_{2} \mathrm{O}_{5}$ and $\mathrm{AlF}_{3}$ as catalysts for the development of low temperature mullite. The composite materials included $6 \mathrm{H}-\mathrm{SiC}$, mullite, cristobalite and alumina as crystalline phases. The authors pointed out a significant increase in the amount of mullite from $1250^{\circ} \mathrm{C}$, at the expense of the decrease of alumina in the sintered samples, which caused an improvement in the bending strength, as well as the reduction in the porosity. The microstructure consisted of rod-shaped mullite crystals and plate-shaped $\mathrm{SiC}$ grains distributed among the mullite particles. The samples sintered at $1350{ }^{\circ} \mathrm{C}$ showed optimum behavior, with a bending strength of $49.4 \mathrm{MPa}$ and a porosity of $31.4 \%$. The authors highlighted that the introduction of $\mathrm{V}_{2} \mathrm{O}_{5}$ and $\mathrm{AlF}_{3}$ changed the mechanism of the mullite formation reaction, significantly reducing the sintering temperature. Thus, $\mathrm{AlF}_{3}$ is converted into vapor phase fluorine and reacts with aluminum oxide and silicon oxide to generate $\mathrm{SiF}_{4}$ and $\mathrm{AlOF}$, respectively. In this way, the growth of the crystal nucleus is accelerated along an axis, causing the quick formation of a significant amount of mullite crystals.

In addition to the red sludge, the Bayer process generates an alumina-rich residue (90 wt.\%), which can be used as a source of alumina in the manufacture of porcelain. Da Silva et al. [95] reported the manufacture of porous mullite blocks from mixtures of kaolin and Bayer alumina waste. The alumina waste consisted mainly of $\mathrm{Al}_{2} \mathrm{O}_{3}$, with $\mathrm{SiO}_{2}$ and $\mathrm{SO}_{3}$ as minor components. Regarding its mineralogical composition, in addition to alumina, the waste contained $\mathrm{Na}_{2} \mathrm{O}$ and sulfur phases as impurities. Mixtures of kaolin and alumina residue were formulated to achieve the stoichiometry of mullite 3:2. After firing, all samples included mullite as the main crystalline phase, together with corundum $(\alpha-$ alumina) and quartz. The mullite content was increased by the firing temperature, resulting in an enhancement of the mechanical properties of the fired materials. The microstructural study revealed the bimodal growth of primary mullite acicular crystals, developed in the glass matrix, and smaller crystals of secondary mullite (Figure 5). The authors highlighted 
the possibility of recovering Bayer's alumina residue to produce mullite materials suitable for applications requiring high porosity and strength at high temperatures.

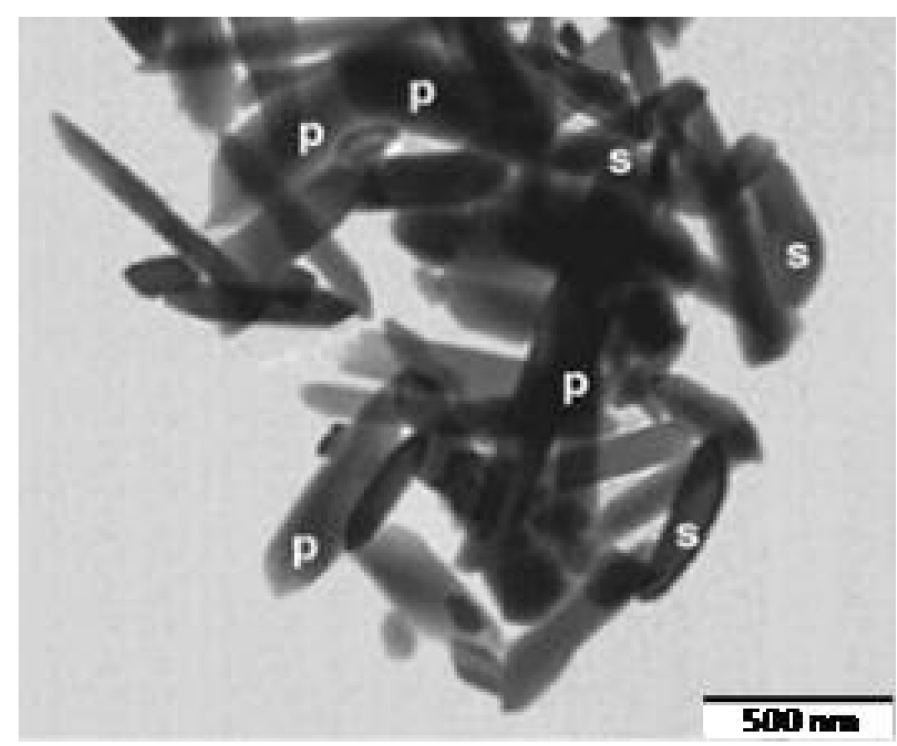

Figure 5. TEM image of the mullite crystals developed at $1450{ }^{\circ} \mathrm{C}$ in porous mullite blocks from Bayer alumina waste and kaolin (p and s denotes primary and secondary mullite, respectively) [95].

\subsection{Boron Mining Waste}

Boron is mainly demanded for the manufacture of fiberglass. However, it is also an essential element in agriculture (herbicides and pesticides) and in the production of ceramic materials, borosilicate glass and detergents [96]. Other uses of boron include the manufacture of special steels with high resistance to impact, and also its application in the field of atomic energy. Because of its high neutron absorption capacity, it is used as a control buffer in nuclear reactors and as a constituent material of neutron shields. In 2019, world production of boron was approximately $3.8 \times 10^{6}$ metric tons, being led by Turkey with $2.5 \times 10^{6}$ metric tons [5]. Studies on the valorization of boron mining wastes have focused mainly on the development of cement [97], concrete [98] and geopolymers [99]. However, some research has explored its incorporation into mullite-based ceramic materials, as detailed below. Tables 7-9 present the chemical composition of boron mining wastes, processing parameters and technological properties of the ceramic materials developed.

Table 7. Chemical composition (expressed wt.\% oxide) of boron mining wastes.

\begin{tabular}{|c|c|c|c|c|c|c|c|c|c|c|}
\hline Reference & Waste & $\mathrm{SiO}_{2}$ & $\mathrm{Al}_{2} \mathrm{O}_{3}$ & $\mathrm{Fe}_{2} \mathrm{O}_{3}$ & $\mathrm{CaO}$ & $\mathrm{MgO}$ & $\mathrm{Na}_{2} \mathrm{O}$ & $\mathrm{K}_{2} \mathrm{O}$ & $\mathrm{B}_{2} \mathrm{O}_{3}$ & LOI \\
\hline [100] & (1) & 15.83 & 1.06 & 0.24 & 20.66 & 19.84 & 2.58 & 0.63 & 3.99 & 34.75 \\
\hline$[101,102]$ & (2) & 0.39-19.81 & $0.11-0.74$ & $0.13-0.33$ & $23.31-52.75$ & $0.60-8.96$ & $0.00-1.34$ & $0.00-0.17$ & $16.37-31.11$ & $14.68-30.74$ \\
\hline
\end{tabular}

nd = not determined; (1) Tincalconite; (2) Colemanite.

Table 8. Experimental conditions used in the development of mullite-based materials from boron mining wastes.

\begin{tabular}{|c|c|c|c|c|c|}
\hline Reference & Mining Waste & $\begin{array}{c}\text { Percentage of Use } \\
\text { (wt.\%) }\end{array}$ & $\begin{array}{c}\text { Additional Raw Materials } \\
\text { (wt.\%) }\end{array}$ & Shaping Method & $\begin{array}{c}\text { Sintering } \\
\text { Conditions }\end{array}$ \\
\hline [100] & Tincalconite & $2-16$ & $\begin{array}{c}\text { Clay (60) } \\
\text { Feldespatic waste (24-40) }\end{array}$ & $\begin{array}{c}\mathrm{UP} ; 16 \mathrm{MPa} \\
110 \times 55 \times 6 \mathrm{~mm}\end{array}$ & $\begin{array}{l}1050-1150^{\circ} \mathrm{C} \\
2^{\circ} \mathrm{C} / \mathrm{min} ; 1 \mathrm{~h}\end{array}$ \\
\hline [101] & Colemanite & $1-14.80$ & $\mathrm{nr}$ & $\begin{array}{c}\mathrm{UP} \\
15 \times 5 \times 5 \mathrm{~mm}\end{array}$ & $\begin{array}{l}1120-1195^{\circ} \mathrm{C} \\
4 \mathrm{~min}\end{array}$ \\
\hline [102] & Colemanite & $1.10-8.56$ & $\mathrm{nr}$ & $\begin{array}{c}\mathrm{UP} \\
\varnothing 50 \mathrm{~mm} \\
5 \times 10 \mathrm{~cm}\end{array}$ & $\begin{array}{l}1180-1230^{\circ} \mathrm{C} \\
\quad 4 \mathrm{~min}\end{array}$ \\
\hline
\end{tabular}


Table 9. Technological properties of mullite-based materials developed from boron mining wastes.

\begin{tabular}{cccccc}
\hline Reference & Mining Waste & Final Material & $\begin{array}{c}\text { Flexural Strength } \\
\mathbf{( M P a )}\end{array}$ & $\begin{array}{c}\text { Water Absorption } \\
\mathbf{( \% )}\end{array}$ & $\begin{array}{c}\text { Firing Shrinkage } \\
\mathbf{( \% )}\end{array}$ \\
\hline$[100]$ & Tincalconite & Terracota tiles & $16-44$ & $0.1-14$ & $3.0-8.5$ \\
{$[101]$} & Colemanite & Wall and floor tiles & 38.43 & 0.49 & 6.8 \\
{$[102]$} & Colemanite & Porcelain tiles & 44.80 & 0.01 & 7.4 \\
\hline
\end{tabular}

nd $=$ not determined

Kurama et al. [100] investigated the production of terracotta tiles with improved physical-mechanical properties and lower production costs, using the tincalconite sieve dewatering residue (TSW) generated in the manufacture of borax $\left.\left(\mathrm{Na}_{2} \mathrm{~B}_{4} \mathrm{O}_{5}(\mathrm{OH})_{4}\right] \cdot 8 \mathrm{H}_{2} \mathrm{O}\right)$ from the mineral tincalconite $\left(\mathrm{Na}_{2} \mathrm{~B}_{4} \mathrm{O}_{4}(\mathrm{OH})_{4} \cdot 3 \mathrm{H}_{2} \mathrm{O}\right)$. It is estimated that $0.5 \mathrm{t}$ of this waste is produced in the production of $1 \mathrm{t}$ of borax. TSW was composed of $\mathrm{SiO}_{2}, \mathrm{CaO}$ and $\mathrm{MgO}$ as major oxides and $\mathrm{Al}_{2} \mathrm{O}_{3}, \mathrm{~B}_{2} \mathrm{O}_{3}$ and alkaline oxides as minor components. In terms of mineralogy, TSW was comprised of dolomite $\left(\mathrm{CaMg}\left(\mathrm{CO}_{3}\right)_{2}\right.$, tincalconite, montmorillonite and calcite. The authors noted that the water absorption of fired materials decreased considerably when the TSW content in the paste composition increased, which was attributed both to the strong melting action of its $\mathrm{B}_{2} \mathrm{O}_{3}$ content and to the sintering-promoting character of the alkaline earth oxides $(\mathrm{MgO}$ and $\mathrm{CaO})$, whose content in this waste was considerably higher than in the other constituent raw materials. As a consequence, the bending strength was also increased by the TSW content in the composition. The main crystalline phase in the fired materials was quartz, which was largely a remnant of the initial quartz contained in the raw materials. As for the newly formed phases, mullite was the main crystalline phase developed during firing. The study also showed that the content of the amorphous phase increased regularly as the amount of TSW incorporated into the composition increased. However, Cicek et al. [101] considered that the use of tincalconite extraction/enrichment tailings into the ceramic tile manufacturing sector was not feasible, as they contain a high percentage of $\mathrm{Na}_{2} \mathrm{O}$, which is a very energetic flux and provides excessive fluidity to the ceramic body. Therefore, its use in industrial ceramic tile production, where a fast-firing cycle with very fast heating and cooling speeds is applied, is not feasible. Therefore, they developed pavement and covering ceramic tiles using tailings from the manufacture of boric acid $\left(\mathrm{H}_{3} \mathrm{BO}_{3}\right)$ from the mineral colemanite $\left(\mathrm{CaB}_{3} \mathrm{O}_{4}(\mathrm{OH})_{3} \cdot \mathrm{H}_{2} \mathrm{O}\right)$. In this case, new formulations of floor ceramic tiles were prepared with percentages of alkaline earth oxides and $\mathrm{SiO}_{2} / \mathrm{Al}_{2} \mathrm{O}_{3}, \mathrm{Na}_{2} \mathrm{O} / \mathrm{K}_{2} \mathrm{O}$ and $\mathrm{MgO} / \mathrm{CaO}$ ratios similar to those of commercial compositions. The authors noted that compositions containing $5.66 \mathrm{wt} . \%$ colemanite tailings presented a densification temperature $65^{\circ} \mathrm{C}$ below that used in the manufacture of ceramic floor tiles. The $\mathrm{B}_{2} \mathrm{O}_{3}$ content in the tailings favored the generation of liquid phases, thus facilitating viscous sintering at a slightly lower temperature than that used in commercial manufacture. The major crystalline phases were anorthite, albite $\left(\mathrm{Na}\left(\mathrm{AlSi}_{3} \mathrm{O}_{8}\right)\right)$, mullite and quartz. Plagioclase formation $\left((\mathrm{Na}, \mathrm{Ca})(\mathrm{Si}, \mathrm{Al})_{3} \mathrm{O}_{8}\right)$ was promoted by the high Ca content of the boron tailings. These tiles showed shrinkage during firing similar to standard tiles and presented lower water absorption values $(0.49 \%)$. However, the bending strength (38.43 MPa) decreased considerably with respect to commercial floor tiles due to the formation of excess plagioclase, which is harder but less resistant. In a recent study, Karadagli and Cicek [102] studied the introduction of this same colemanite tailing in the manufacture of porcelain stoneware tiles. They incorporated 3-10 wt.\% of tailings into a formulation used for commercial production of porcelain tiles. The authors achieved a decrease in the sintering temperature of $38^{\circ} \mathrm{C}$. The new tiles showed bending strength $(44.80 \mathrm{MPa})$ and water absorption $(0.01 \%)$ values complying with the requirements for porcelain tile.

\subsection{Molybdenum Mining Waste}

Molybdenum is mainly used for the manufacture of resistant steels, but it is also required as a component of superalloys, nickel alloys and in other industrial sectors such as lubricants, chemicals and electronics. World production of molybdenum in 2019 was 
$290 \times 10^{3}$ metric tons [6], with production being led by China with $130 \times 10^{3}$ metric tons [103]. In the literature, the works focused on the valorization of Mo mining wastes are scarce, being focused on its incorporation in cement and concrete $[104,105]$. Moreover, Karhu et al. [106] investigated the use of molybdenum tailings as raw materials for producing mullite-based ceramics. Table 10 displays the chemical composition, processing parameters and technological properties of the ceramic materials. Molybdenum tailings were mainly composed of $\mathrm{SiO}_{2}$ and $\mathrm{Al}_{2} \mathrm{O}_{3}$ and a considerable content (22 wt.\%) of minor components $\left(\mathrm{CaO}, \mathrm{Fe}_{2} \mathrm{O}_{3}, \mathrm{~K}_{2} \mathrm{O}, \mathrm{Na}_{2} \mathrm{O}\right.$ and $\left.\mathrm{MgO}\right)$. The main mineral phases were quartz (40 wt. $\%)$, albite $(23 \mathrm{wt} . \%)$ and andesite $\left(\left(\mathrm{Ca}, \mathrm{Na}_{)} \mathrm{Al}_{2} \mathrm{Si}_{2} \mathrm{O}_{8}, 12 \mathrm{wt} . \%\right)\right.$, together with minor amounts of K-feldspar $(6 \mathrm{wt} . \%)$, biotite $\left(\mathrm{K}\left(\mathrm{Mg}, \mathrm{Fe}^{2+}\right)_{6}(\mathrm{Si}, \mathrm{Al})_{8} \mathrm{O}_{20}(\mathrm{OH})_{4} \cdot \mathrm{nH}_{2} \mathrm{O}, 6 \mathrm{wt} . \%\right)$ and muscovite $\left(\mathrm{KAl}_{2}\left(\mathrm{Si}_{3} \mathrm{Al}\right) \mathrm{O}_{10}(\mathrm{OH})_{2}, 3 \mathrm{wt} . \%\right)$. Sintering of tailings and boehmite mixtures resulted in crystalline materials including mullite as the main crystalline phase, along with corundum and amorphous phase. The microstructure of these materials was composed of acicular mullite crystals surrounded by a glassy phase. During sintering, the alkali and K-mica feldspars contained in Mo tailings led to a liquid phase that facilitated the reaction of the silica with the alumina caused by the thermal decomposition of boehmite and the subsequent crystallization of mullite.

Table 10. Chemical composition (expressed wt.\% oxide), processing parameters and technological properties of ceramic materials developed from molybdenum mining waste.

\begin{tabular}{|c|c|c|c|c|c|c|c|}
\hline Reference & $\mathrm{SiO}_{2}$ & $\mathrm{Al}_{2} \mathrm{O}_{3}$ & $\mathrm{Fe}_{2} \mathrm{O}_{3}$ & $\mathrm{CaO}$ & $\mathrm{MgO}$ & $\mathrm{Na}_{2} \mathrm{O}$ & $\mathrm{K}_{2} \mathrm{O}$ \\
\hline \multirow{3}{*}{ [106] } & 73.2 & 11.1 & 2.93 & 1.95 & 4.84 & 3.45 & 1.51 \\
\hline & $\begin{array}{c}\text { Final } \\
\text { material }\end{array}$ & $\begin{array}{c}\text { Percentage } \\
\text { of use } \\
\text { (wt. } \%)\end{array}$ & $\begin{array}{c}\text { Additional } \\
\text { raw } \\
\text { materials } \\
\text { (wt. } \%)\end{array}$ & $\begin{array}{l}\text { Shaping } \\
\text { method }\end{array}$ & $\begin{array}{l}\text { Sintering } \\
\text { conditions }\end{array}$ & $\begin{array}{l}\text { Compressive } \\
\text { strength } \\
\text { (MPa) }\end{array}$ & $\begin{array}{l}\text { Apparent density } \\
\left(\mathrm{g} / \mathrm{cm}^{3}\right)\end{array}$ \\
\hline & $\begin{array}{l}\text { Mullite- } \\
\text { based } \\
\text { ceramics }\end{array}$ & $33.6-83.5$ & $\begin{array}{l}\text { Boehmite } \\
(16.5-66.4)\end{array}$ & $\begin{array}{l}\mathrm{UP} ; 25 \mathrm{MPa} \\
20 \times 3 \mathrm{~mm}\end{array}$ & $\begin{array}{c}1300{ }^{\circ} \mathrm{C} \\
3.3^{\circ} \mathrm{C} / \mathrm{min} ; \\
3 \mathrm{~h}\end{array}$ & $\sim 62$ & 2.7 \\
\hline
\end{tabular}

nd $=$ not determined; $\mathrm{UP}=$ uniaxial pressing.

\subsection{Lithium Mining Waste}

In the last years, lithium has become one of the key chemical elements for new technologies. Although lithium has long been used in different industrial sectors, the development of lithium-ion batteries has resulted in lithium becoming a key mineral, as lithium batteries are essential for the development of smartphones, laptops, hybrid and electric cars or rechargeable devices, such as solar charging lithium ion batteries. World lithium production in 2019 was 77,000 metric tons, with Australia (42,000 metric tons) and Chile (18,000 metric tons) being the major producers [107]. By 2025, the global demand for lithium is estimated to be 820,000 metric tons of lithium carbonate equivalent [108]. One of the main routes of lithium extraction is acid roasting with $\mathrm{H}_{2} \mathrm{SO}_{4}$ of the mineral spodumene $\left(\mathrm{LiAlSi}_{2} \mathrm{O}_{6}\right)$, which contains approximately $8 \%$ of $\mathrm{Li}_{2} \mathrm{O}$ [109-111]. Lemougna et al. [112] studied the use of quartz feldspar sand (QFS) residues originating during the chemical production of lithium from spodumene as a raw material for the manufacture of porcelain and structural materials. Table 11 shows the chemical composition of this waste together with the processing parameters and technological properties of the final ceramic materials. 
Table 11. Chemical composition (expressed wt.\% oxide), processing parameters and technological properties of ceramic materials developed from lithium mining waste.

\begin{tabular}{|c|c|c|c|c|c|c|c|c|}
\hline Reference & $\mathrm{SiO}_{2}$ & $\mathrm{Al}_{2} \mathrm{O}_{3}$ & $\mathrm{Fe}_{2} \mathrm{O}_{3}$ & $\mathrm{CaO}$ & $\mathrm{P}_{2} \mathrm{O}_{5}$ & $\mathrm{Na}_{2} \mathrm{O}$ & $\mathrm{K}_{2} \mathrm{O}$ & LOI \\
\hline \multirow{6}{*}{ [112] } & 77.50 & 13.5 & 0.20 & 0.30 & 0.10 & 4.80 & 3.30 & 0.0 \\
\hline & $\begin{array}{c}\text { Final } \\
\text { material }\end{array}$ & $\begin{array}{l}\text { Percentage of use } \\
\text { (wt. \%) }\end{array}$ & $\begin{array}{c}\text { Additional } \\
\text { raw } \\
\text { materials } \\
\text { (wt. } \%)\end{array}$ & Shaping method & \multicolumn{4}{|c|}{ Sintering conditions } \\
\hline & $\begin{array}{l}\text { Porcelain } \\
\text { materials } \\
\text { Structural } \\
\text { materials }\end{array}$ & $80-90$ & $\begin{array}{c}\text { Kaolin (50) } \\
\text { Quartz (0-9) } \\
\text { Kaolin } \\
(10-20)\end{array}$ & $\begin{array}{l}\text { Slip casting } \\
80 \times 20 \times 20 \mathrm{~mm} \\
\text { Slip casting } \\
80 \times 20 \times 20 \mathrm{~mm}\end{array}$ & \multicolumn{4}{|c|}{$\begin{array}{c}1050-1200^{\circ} \mathrm{C} \\
5^{\circ} \mathrm{C} / \mathrm{min} ; 2 \mathrm{~h} \\
1050{ }^{\circ} \mathrm{C} \\
5{ }^{\circ} \mathrm{C} / \mathrm{min} ; 2 \mathrm{~h}\end{array}$} \\
\hline & $\begin{array}{c}\text { Final } \\
\text { material }\end{array}$ & $\begin{array}{l}\text { Compressive } \\
\text { strength (MPa) }\end{array}$ & $\begin{array}{c}\text { Flexural } \\
\text { strength } \\
(\mathrm{MPa})\end{array}$ & $\begin{array}{c}\text { Water } \\
\text { absorption (\%) }\end{array}$ & \multicolumn{2}{|c|}{$\begin{array}{c}\text { Apparent } \\
\text { density }\left(\mathrm{g} / \mathrm{cm}^{3}\right)\end{array}$} & \multicolumn{2}{|c|}{ Firing shrinkage $(\%)$} \\
\hline & $\begin{array}{l}\text { Porcelain } \\
\text { materials }\end{array}$ & $40-90$ & $10-30$ & $0.2-18$ & \multicolumn{2}{|c|}{$1.7-2.5$} & \multicolumn{2}{|c|}{$2-18$} \\
\hline & $\begin{array}{l}\text { Structural } \\
\text { materials }\end{array}$ & $67-69$ & $16.5-17.5$ & $6.3-6.8$ & \multicolumn{2}{|c|}{$2.05-2.07$} & \multicolumn{2}{|c|}{ nd } \\
\hline
\end{tabular}

nd = not determined; UP = uniaxial pressing.

The QFS residue was composed of $\mathrm{SiO}_{2}$ as the major oxide and $\mathrm{Al}_{2} \mathrm{O}_{3}$, and alkaline oxides as minor components. From a mineralogical point of view, spodumene waste included albite (44 wt.\%), quartz (32 wt.\%), microcline ( $\mathrm{KAlSi}_{3} \mathrm{O}_{8} ; 11 \mathrm{wt.} \%$ ) and muscovite $(6 \mathrm{wt.} \%)$ together with amorphous phase (7 wt.\%) (Figure 6). The porcelain materials obtained after a sintering process were mainly composed of quartz (13-26 wt.\%), mullite (12-20 wt.\%) and amorphous phase (42-56 wt.\%), the highest percentages of mullite being obtained for materials sintered at $1200{ }^{\circ} \mathrm{C}$ (Figure 7). These materials presented the best technological properties, with a dense and compact microstructure with microstructural characteristics similar to those of reference porcelain compositions. The highest compressive strength values of $90 \mathrm{MPa}$ fulfilled the requirements for fired bricks, masonry bricks and ceramic pavers exposed to light traffic. As regards to bending strength, maximum values of $30 \mathrm{MPa}$ were achieved, which are slightly lower than those presented by commercial porcelain stoneware tiles. Materials sintered at $1200^{\circ} \mathrm{C}$ showed very low water absorption values $(0.2 \%)$ corresponding to an apparent density of $2.5 \mathrm{~g} \cdot \mathrm{cm}^{-3}$, both properties being comparable to those reported in studies of porcelain materials. The shrinkage values on sintering were also similar to the values of approximately $20 \%$ shrinkage reported for some porcelain compositions fired at $1200^{\circ} \mathrm{C}$. As for the properties of structural materials manufactured with 80 and $90 \mathrm{wt} . \%$ of spodumene tailings, they exhibited values of compressive strength exceeding 17-20 MPa, which is the value required for ceramic pavers subjected to light traffic. Similarly, they showed water absorption well below $15 \%$, complying with the requirement for ceramics with construction applications. 


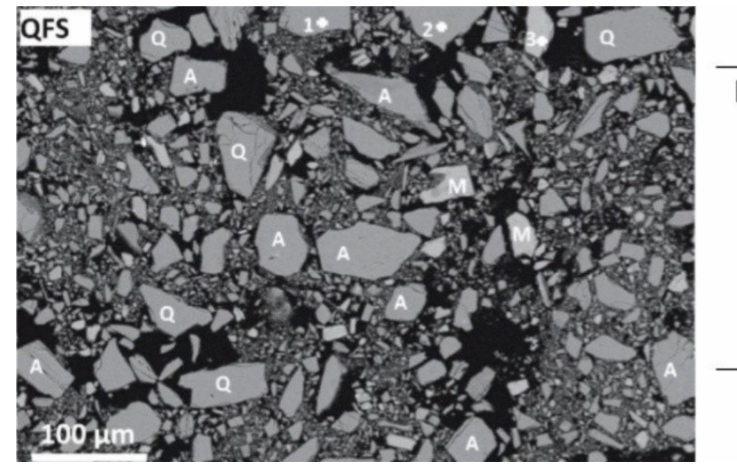

\begin{tabular}{cccc}
$\begin{array}{c}\text { Element } \\
\text { (wt.\%) }\end{array}$ & $\begin{array}{c}\text { 1: Quartz } \\
\text { (Q) }\end{array}$ & $\begin{array}{c}\text { 2: Albite } \\
\text { (A) }\end{array}$ & $\begin{array}{c}\text { 3: Microcline } \\
\text { (M) }\end{array}$ \\
$\mathrm{O}$ & 48.44 & 44.12 & 41.65 \\
$\mathrm{Si}$ & 51.56 & 35.42 & 32.97 \\
$\mathrm{Al}$ & - & 11.52 & 10.68 \\
$\mathrm{Na}$ & - & 8.95 & 0.43 \\
$\mathrm{~K}$ & - & - & 14.27 \\
\hline
\end{tabular}

Figure 6. SEM of QFS powder [112].

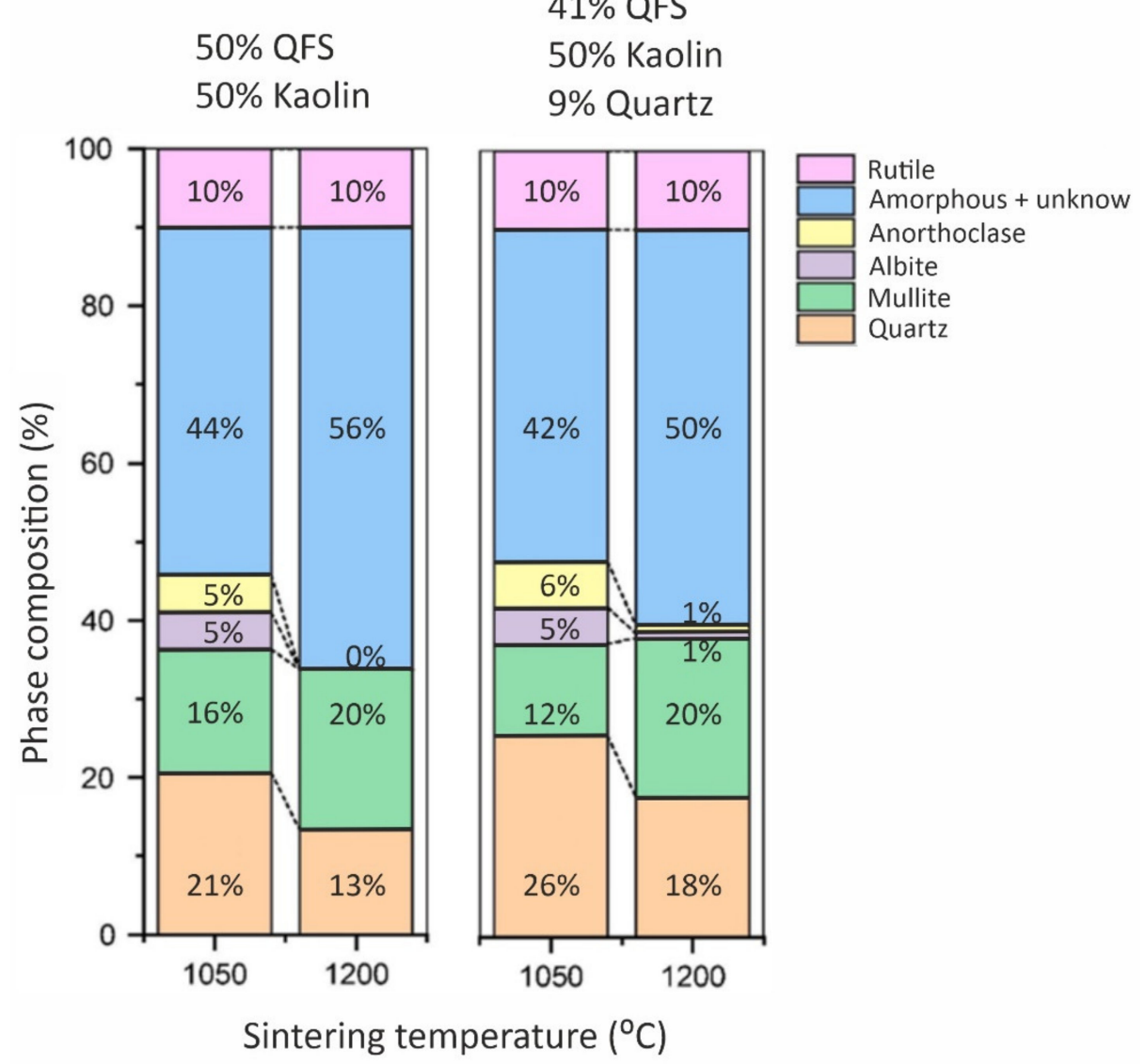

Figure 7. Phase composition of investigated compositions at indicated temperatures [112].

\section{Waste from Mineral Extraction}

\subsection{Coal Gangue}

Coal is a major energy source worldwide, in 2018, the energy produced from coal accounted for $31.2 \%$ of primary energy generated from non-renewable sources [113]. In 2018, global hard coal production was $7.08 \times 10^{9}$ metric tons, with the market being led by China (3.53 $\times 10^{9}$ metric tons) [114]. During mining and subsequent coal washing, coal gangue is generated as a solid waste, amounting to approximately $10-15 \%$ of coal production [115]. In recent years, an increased demand for the appropriate and efficient use of coal gangue has been observed in different sectors. Thus, several studies can be found in the literature aimed at the use of this waste in geotechnical applications [116], alkaline-activated materials [117,118], as zinc and manganese ion adsorbent $[119,120]$ or in agricultural applications [121]. Commonly, coal gangue is composed of a mixture of sandstone, shale and carbonaceous slate, with $\mathrm{SiO}_{2}$ and $\mathrm{Al}_{2} \mathrm{O}_{3}$ as its main chemical 
constituents. Therefore, another way of valorization is its use in the manufacture of mullitebased ceramics. Tables 12-14 present the chemical composition of coal waste, processing parameters and technological properties of the ceramic materials developed.

Table 12. Chemical composition (expressed wt.\% oxide) of coal gangue.

\begin{tabular}{cccccccccc}
\hline Reference & $\mathrm{SiO}_{2}$ & $\mathrm{Al}_{2} \mathbf{O}_{3}$ & $\mathrm{Fe}_{\mathbf{2}} \mathbf{O}_{3}$ & $\mathbf{C a O}$ & $\mathbf{M g O}$ & $\mathbf{N a}_{2} \mathbf{O}$ & $\mathbf{K}_{\mathbf{2}} \mathbf{O}$ & $\mathrm{TiO}_{2}$ & $\mathbf{L O I}$ \\
\hline$[122]$ & 45.55 & 37.56 & 0.23 & 0.44 & 0.43 & 0.16 & 0.21 & 0.37 & 15.30 \\
{$[123]$} & 65.21 & 26.68 & - & 0.30 & 0.84 & 0.43 & 3.16 & 1.24 & 16.70 \\
{$[124]$} & 30.70 & 27.40 & 8.10 & 0.30 & - & - & - & 2.70 & 30.80 \\
{$[125]$} & $48.5-54.1$ & $21.80-$ & $4.2-8.6$ & $2.6-3.4$ & $1.7-2.5$ & $0.4-0.6$ & $1.3-1.6$ & & nd \\
\hline
\end{tabular}

nd $=$ not determined

Table 13. Experimental conditions used in the development of mullite-based materials from coal gangue.

\begin{tabular}{|c|c|c|c|c|}
\hline Reference & $\begin{array}{l}\text { Percentage of Use } \\
\text { (wt.\%) }\end{array}$ & $\begin{array}{c}\text { Additional Raw Materials } \\
\text { (wt.\%) }\end{array}$ & Shaping Method & Sintering Conditions \\
\hline [122] & 45.61 & $\gamma-\mathrm{Al}_{2} \mathrm{O}_{3}(54.39)$ & $\mathrm{UP} ; 200 \mathrm{MPa}$ & $\begin{array}{c}1400-1550{ }^{\circ} \mathrm{C} \\
4 \mathrm{~h}\end{array}$ \\
\hline [123] & 73.79 & $\mathrm{Al}_{2} \mathrm{O}_{3}(26.21)$ & $\begin{array}{c}\mathrm{UP} ; 20 \mathrm{MPa} \\
70 \times 10 \times 10 \mathrm{~mm}\end{array}$ & $\begin{array}{l}1300-1550{ }^{\circ} \mathrm{C} \\
3{ }^{\circ} \mathrm{C} / \mathrm{min} ; 3 \mathrm{~h}\end{array}$ \\
\hline [124] & 50.0 & Low-grade bauxite (50.0) & Pelletizing & $\begin{array}{l}1200-1450{ }^{\circ} \mathrm{C} \\
5^{\circ} \mathrm{C} / \mathrm{min} ; 2 \mathrm{~h}\end{array}$ \\
\hline [125] & 50.00 & $\begin{array}{l}\text { High alumina refractory solid } \\
\text { wastes }(50.00)\end{array}$ & $\begin{array}{c}\mathrm{UP} ; 200 \mathrm{MPa} \\
4 \times 6 \times 50 \mathrm{~mm}\end{array}$ & $\begin{array}{c}1300-1400{ }^{\circ} \mathrm{C} \\
3 \mathrm{~h}\end{array}$ \\
\hline
\end{tabular}

$\mathrm{UP}=$ uniaxial pressing.

Table 14. Technological properties of mullite-based materials developed from coal gangue.

\begin{tabular}{ccccc}
\hline Reference & Final Material & $\begin{array}{c}\text { Flexural Strength } \\
(\mathbf{M P a})\end{array}$ & Water Absorption (\%) & $\begin{array}{c}\text { Apparent Density } \\
\left(\mathbf{g} / \mathbf{c m}^{\mathbf{3}}\right)\end{array}$ \\
\hline$[122]$ & Mullite ceramics & $25-218$ & nd & $1.89-3.20$ \\
{$[123]$} & Mullite ceramics & $80-97$ & $0.26-7$ & $2.06-2.40$ \\
{$[124]$} & Mullite based & nd & nd & $2.64-2.85$ \\
{$[125]$} & proppants & $47-72$ & nd & $2.25-2.50$ \\
\hline
\end{tabular}

nd $=$ not determined.

Ji et al. [122] studied the manufacture of mullite ceramics from coal gangue and $\gamma$ $\mathrm{Al}_{2} \mathrm{O}_{3}$ with the addition of $\mathrm{La}_{2} \mathrm{O}_{3}$ as a catalyst. The carbon gangue was composed of kaolinite as the only crystalline phase. After firing, the sintered materials consisted of mullite with an orthorhombic structure, corundum and cristobalite in different proportions. The results highlighted that in the materials sintered at $1500{ }^{\circ} \mathrm{C}$ and containing $5 \mathrm{~mol} \%$ of $\mathrm{La}_{2} \mathrm{O}_{3}$, almost complete mullitization was achieved. The formation of secondary mullite proceeds through a mechanism of dissolution-crystallization from a liquid phase. The addition of $\mathrm{La}_{2} \mathrm{O}_{3}$ reduced the formation temperature of this phase, thus promoting the development of secondary mullite and giving rise to a microstructure formed by interlocking mullite crystals with an aspect ratio of 3-6. The fired materials developed in this way had extraordinary mechanical properties (bending strength up to $218 \mathrm{MPa}$ ) (Figure 8) so that these materials could be used in engineering applications. 


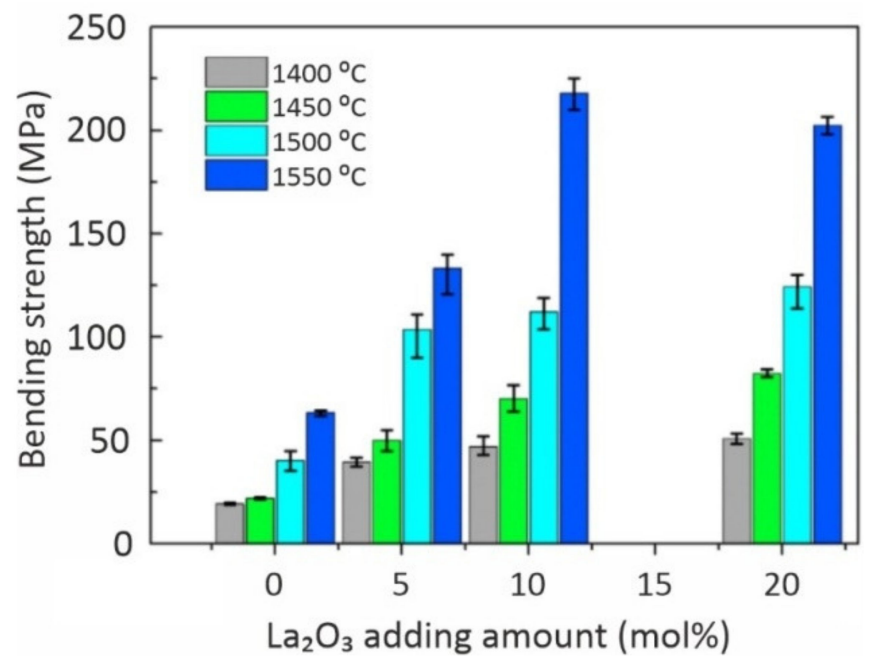

Figure 8. Bending strength versus $\mathrm{La}_{2} \mathrm{O}_{3}$ content at differentsintering temperatures [122].

Dong et al. [123] investigated the development of mullite with a columnar structure using a coal gangue (kaolinite and quartz) and $\mathrm{Al}_{2} \mathrm{O}_{3}$ with the addition of mineralizers ( $2 \%$ $\mathrm{V}_{2} \mathrm{O}_{5}, 1 \% \mathrm{MnO}_{2}$ and $3 \% \mathrm{AlF}_{3}$ ). After sintering, the materials consisted of mullite as the only crystalline phase. As the firing temperature increased, the mullite crystals showed a more acicular morphology and their length increased. In addition, the crystals included $\mathrm{Ca}, \mathrm{Fe}, \mathrm{V}, \mathrm{F}$ and $\mathrm{Ti}$ in a small proportion, indicating that these crystals developed from a glassy phase that included the impurities of the coal gangue. The materials presented a microstructure composed of cross-linked mullite crystals, which contributed to the high values of bending strength of the materials. The results concluded that $1400{ }^{\circ} \mathrm{C}$ was the most suitable temperature for the synthesis of mullite-based materials from coal gangue. At this temperature, the highest value of bending strength was obtained (97.6 MPa).

Another application for the coal gangue could be in the manufacture of proppant, small ceramic balls used in oil extraction. Proppant is used in the hydraulic fragmentation of the rock to prevent cracks from closing and thereby facilitate extraction. Traditionally, mullite-corundum-based proppants are produced from high quality bauxite. Li et al. [124] reported the use of coal gangue to partially replace bauxite in the fabrication of proppants through a pelletization and sintering process. The fired materials were comprised of mullite as the main crystalline phase, along with a small amount of quartz and corundum. An important characteristic of proppant is its resistance to fracture, which is evaluated by the breakage ratio. The materials prepared from coal gangue showed breakage ratio values of less than $10 \%$, complying with the requirements established by the regulations. The authors attributed this good performance to the development of rod-like mullite crystals, which formed a dense cross-linked structure that slowed down the growth of internal microcracks. Finally, the roundness and sphericity of the developed proppants exceeded 0.9 , fulfilling the industrial requirements.

Recently, Liu et al. [125] synthesized a needle-like mullite powder by solid-state reaction of a coal gangue and a high alumina refractory residue. The mullite crystals had an aspect ratio of $\sim 6$. Subsequently, mullite-based ceramics were prepared from the needle-like mullite powder by sintering, which exhibited a microstructure consisting of interlinked needle-like crystals with bending strength values of up to $72 \mathrm{MPa}$.

\subsection{Kaolin Processing Waste}

Kaolin is a dioctahedral phyllosilicate composed of $46.5 \mathrm{wt} . \% \mathrm{SiO}_{2}, 39.5 \mathrm{wt} . \% \mathrm{Al}_{2} \mathrm{O}_{3}$ and $14.0 \mathrm{wt.} \% \mathrm{H}_{2} \mathrm{O}$ [126]. Kaolin is a mixture of clay minerals, mainly kaolinite, and it is formed by the alteration of feldspar-rich rocks. This is one of the clay minerals with more industrial applications due to its characteristics, such as: chemically inert in a wide range of $\mathrm{pH}(4-9)$, non-abrasive, low heat and electricity conductivity, low surface area 
compared to other clay minerals, white or almost white color [127]. Thus, kaolin is involved in the manufacture of different materials such as paper, ceramics, refractories, paints and polymers, as well as in the synthesis of pesticides and fertilizers and in the production of cosmetics. Global kaolin extraction in 2018 reached $29 \times 10^{6}$ metric tons. The United States, with $7.3 \times 10^{6}$ metric tons was the largest producing country, followed by China and Ukraine with $3.2 \times 10^{6}$ and $2.1 \times 10^{6}$ metric tons, respectively [9].

As extracted from the mine, the kaolin ore contains a variable amount of kaolinite, sometimes fewer than $20 \%$. In addition, it often contains impurities such as quartz, feldspars and micas. Therefore, once extracted, kaolin goes through a beneficiation process that includes successive washing, crushing, drying and grinding steps. As a consequence of this process, a large amount of waste is generated, estimated at around $80 \%$ to $90 \%$ of the total volume of the exploited mineral [128]. This fact has prompted various investigations focused on the recovery of waste originating from the extraction of kaolin as a raw material in the manufacture of zeolites [129,130], molecular sieves [131] or cordierite [132]. The studies focused on the valorization of kaolin processing wastes in the manufacture of mullite-based ceramics are summarized below. Tables 15-17 list the chemical composition of primary kaolin industry waste, processing parameters and technological properties of the ceramic materials developed.

Table 15. Chemical composition (expressed wt.\% oxide) of primary kaolin industry waste.

\begin{tabular}{ccccccccccc}
\hline Reference & Waste & $\mathbf{S i O}_{2}$ & $\mathbf{A l}_{\mathbf{2}} \mathbf{O}_{3}$ & $\mathbf{F e}_{2} \mathbf{O}_{3}$ & $\mathbf{M g O}$ & $\mathbf{N a}_{\mathbf{2}} \mathbf{O}$ & $\mathbf{K}_{\mathbf{2}} \mathbf{O}$ & $\mathrm{TiO}_{\mathbf{2}}$ & $\mathbf{L O I}$ \\
\hline$[133]$ & $\begin{array}{c}\text { Primary kaolin industry } \\
\text { waste }\end{array}$ & 57.11 & 40.67 & 0.04 & - & 0.53 & 1.65 & - & $\mathrm{nd}$ \\
\hline$[134-137]$ & $\begin{array}{c}\text { Primary kaolin industry } \\
\text { waste }\end{array}$ & 52.68 & 33.57 & 0.93 & - & 0.08 & 5.72 & 0.12 & 6.75 \\
\hline$[138]$ & Fine kaolin waste & 46.4 & 37.7 & 0.5 & 1.0 & $*$ & 1.4 & $*$ \\
\hline$[138]$ & Coarse kaolin waste & 60.3 & 28.5 & 0.9 & 0.8 & $* *$ & 1.0 & $* *$ \\
\hline
\end{tabular}

$\mathrm{nd}=$ not determined; ${ }^{*}$ other oxides $=0.4 \mathrm{wt} . \%$; ${ }^{* *}$ other oxides $=1.1 \mathrm{wt} . \%$.

Table 16. Experimental conditions used in the development of mullite-based materials from primary kaolin industry waste.

\begin{tabular}{|c|c|c|c|c|}
\hline Reference & $\begin{array}{l}\text { Percentage of Use } \\
\text { (wt.\%) }\end{array}$ & $\begin{array}{c}\text { Additional Raw Materials } \\
\text { (wt.\%) }\end{array}$ & Shaping Method & Sintering Conditions \\
\hline [133] & $66.38-74.12$ & $\begin{array}{l}\text { Alumina (25.88-33.62 wt.\%) } \\
\text { Ball clay (0-7 wt.\%) }\end{array}$ & $\begin{array}{c}\mathrm{UP} ; 27 \mathrm{MPa} \\
60 \times 20 \times 5 \mathrm{~mm}\end{array}$ & $\begin{array}{c}1350-1500^{\circ} \mathrm{C} \\
10^{\circ} \mathrm{C} / \mathrm{min} ; 1 \mathrm{~h}\end{array}$ \\
\hline [134] & $38-54$ & Alumina (46-62 wt.\%) & $\begin{array}{c}\mathrm{UP} ; 30 \mathrm{MPa} \\
60 \times 20 \times 5 \mathrm{~mm}\end{array}$ & $\begin{array}{l}1450-1600^{\circ} \mathrm{C} \\
5{ }^{\circ} \mathrm{C} / \mathrm{min} ; 2 \mathrm{~h}\end{array}$ \\
\hline [135] & $48-74.12$ & $\begin{array}{c}\text { Alumina }(25.88-52.00) \\
\text { Ball clay }(0-7)\end{array}$ & $\begin{array}{c}\mathrm{UP} ; 27 \mathrm{MPa} \\
60 \times 20 \times 5 \mathrm{~mm}\end{array}$ & $\begin{array}{c}1350-1500^{\circ} \mathrm{C} \\
10^{\circ} \mathrm{C} / \mathrm{min} ; 1 \mathrm{~h}\end{array}$ \\
\hline [136] & $16.60-100$ & $\begin{array}{l}\text { Alumina }(0-66.6) \\
\text { Ball clay }(0-6.66)\end{array}$ & $\begin{array}{c}\mathrm{UP} ; 35 \mathrm{MPa} \\
50 \times 20 \times 5 \mathrm{~mm}\end{array}$ & $\begin{array}{l}1300-1400^{\circ} \mathrm{C} \\
5^{\circ} \mathrm{C} / \mathrm{min} ; 2 \mathrm{~h}\end{array}$ \\
\hline [137] & $10-35$ & $\begin{array}{c}\text { Red clay }(35-40) \\
\text { Ball clay }(0-30) \\
\text { Feldspar }(0-48) \\
\text { Calcite }(0-2)\end{array}$ & $\begin{array}{l}\mathrm{UP} ; 27-35 \mathrm{MPa} \\
50 \times 20 \times 5 \mathrm{~mm}\end{array}$ & $\begin{array}{c}1180-1240{ }^{\circ} \mathrm{C} \\
38^{\circ} \mathrm{C} / \mathrm{min} ; 5 \mathrm{~min}\end{array}$ \\
\hline [138] & $\begin{array}{l}\text { Fine }(35.7-78.0) \\
\text { Coarse }(35.7-71)\end{array}$ & $\begin{array}{c}\text { Talc (14-29) } \\
\text { Magnesium hydroxide (0-8) }\end{array}$ & $\begin{array}{c}\mathrm{UP} ; 13.0 \mathrm{MPa} \\
60 \times 20 \times 5 \mathrm{~mm}\end{array}$ & $\begin{array}{l}1150-1250^{\circ} \mathrm{C} \\
5^{\circ} \mathrm{C} / \mathrm{min} ; 2 \mathrm{~h}\end{array}$ \\
\hline
\end{tabular}


Table 17. Technological properties of mullite-based materials developed from primary kaolin industry waste.

\begin{tabular}{|c|c|c|c|c|c|}
\hline Reference & Final Material & MOR (MPa) & $\begin{array}{c}\text { Water Absorption } \\
(\%)\end{array}$ & $\begin{array}{c}\text { Apparent Density } \\
\left(\mathrm{g} / \mathrm{cm}^{3}\right)\end{array}$ & $\begin{array}{c}\text { Firing Shrinkage } \\
(\%)\end{array}$ \\
\hline [133] & Mullite-based ceramics & $40-60$ & $3.20-8.98$ & $2.28-2.40$ & $5.09-6.59$ \\
\hline [134] & Mullite-based ceramics & $\sim 37-77$ & $\sim 0.75-4.60$ & $\sim 2.14-2.50$ & nd \\
\hline [135] & $\begin{array}{l}\text { Porous technical ceramic } \\
\text { bodies }\end{array}$ & $32-67$ & $\sim 9.3-14.5$ & $2.10-2.34$ & $\sim 6.5-2.0$ \\
\hline [136] & Mullite-based ceramics & $10.40-50.37$ & $0.78-10.56$ & nd & nd \\
\hline [137] & Ceramic tiles & $\sim 38-41$ & $\sim 0.5-2$ & $\sim 2.20-2.35$ & $\sim 5.0-6.6$ \\
\hline [138] & $\begin{array}{l}\text { Cordierite-mullite } \\
\text { composites }\end{array}$ & $3-28$ & $0.5-25.6$ & nd & $1.7-9.1$ \\
\hline
\end{tabular}

nd = not determined; MOR = modulus ofrupture

Brasileiro et al. $[133,134]$ reported the use of the residue from the primary kaolin industry as alternative raw material for the production of mullite ceramics. The kaolin residue is mainly composed of $\mathrm{SiO}_{2}, \mathrm{Al}_{2} \mathrm{O}_{3}$ and a considerable amount of fluxing oxides, especially $\mathrm{K}_{2} \mathrm{O}(5.72 \%)$. Its mineralogical composition consisted of kaolinite, quartz and muscovite. Other raw materials used in this study were alumina and ball clay (56.29 wt.\% $\mathrm{SiO}_{2}, 27.10$ wt. $\% \mathrm{Al}_{2} \mathrm{O}_{3}, 1.60$ wt. $\% \mathrm{Fe}_{2} \mathrm{O}_{3}, 0.18$ wt. $\% \mathrm{~K}_{2} \mathrm{O}, 0.70$ wt. $\% \mathrm{TiO}_{2}$ and 0.09 wt. $\%$ $\mathrm{Na}_{2} \mathrm{O}$ ). Different mixtures were prepared based on the stoichiometric composition for mullite formation or with an excess of either silica or alumina. The authors indicated that the mixtures treated at temperatures above $1500{ }^{\circ} \mathrm{C}$ developed, depending on their initial composition, mullite and quartz or mullite and alumina as the only crystalline phases. Regarding water absorption, samples containing higher proportion of kaolin residue exhibited lower water absorption values, while those with higher alumina contents also showed higher bulk density values. On the other hand, Rodríguez Menezes et al. [135] also studied the feasibility of the aforementioned kaolin processing residue for the production of porous technical ceramics and they concluded that highly porous mullite ceramic bodies (porosity above $40 \%$ ) with high flexural strength $(70 \mathrm{MPa}$ ) were possible by sintering a suitable mixture of waste kaolin and alumina at $1500^{\circ} \mathrm{C}$. The authors highlighted that these materials could be used as supports for catalysts, filters, thermal insulators, bioreactors, etc. through a simple and low-cost manufacturing route.

Rodriguez Menezes et al. [136] carried out an investigation on the valorization of this kaolin waste, using a statistical experimental design methodology in order to achieve the targeted properties in the fired materials with the minimum number of experiments. The model showed that the pre-established values for water absorption and modulus of rupture were similar to those obtained experimentally. The results indicated that the statistical design of mixture experiments and response surface methodologies was a useful tool to establish the influence of the content of the kaolin processing residue on the technological properties of mullite-based ceramics and thus to optimize the compositions. The obtained findings showed that alumina-kaolin residue mixtures with high alumina content presented the lowest water absorption values and the highest flexural strength, corroborating the results of the previous study. In this line, Rodríguez Menezes et al. [137] also evaluated the suitability of using this kaolin waste as an alternative raw material for the manufacture of dense mullite bodies and for obtaining ceramic tiles, in the latter in combination with ball clay, feldspar and calcite. The mixture consisting of $20 \mathrm{wt} . \%$ kaolin waste, $30 \mathrm{wt} . \%$ ball clay, $48 \mathrm{wt} . \%$ feldspar and $2 \mathrm{wt} . \%$ calcite resulted in a material comprising mullite, quartz and sodium feldspar after a sintering process at temperatures above $1200{ }^{\circ} \mathrm{C}$. The analysis concluded that the water absorption of the fired tiles was not only related to the amount of fluxes in the raw materials, but also depended on the convenient combination of the particle size distribution of the raw materials. The developed tiles experienced during firing a decrease in linear shrinkage from $1240{ }^{\circ} \mathrm{C}$ onwards, which was attributed to the development of micro-cracks around the quartz grains during cooling as a consequence of the difference between the expansion coefficients of the quartz and the glassy surrounding 
phase. The developed materials presented modulus of rupture values higher than $38 \mathrm{MPa}$, thus demonstrating that the waste from kaolin processing is suitable for the manufacture of ceramic tiles. Furthermore, the authors also investigated the fabrication of high strength dense mullite bodies from mixtures of kaolin waste and alumina. The fired materials were constituted by mullite, quartz and alumina. The results concluded that the most favorable formulations (higher mullite content and lower quartz and alumina) were those with alumina contents higher than $58 \mathrm{wt} . \%$, when sintered at temperatures above $1550{ }^{\circ} \mathrm{C}$.

Recently, Pinheiro de Brito et al. [138] reported the synthesis of cordierite-mullite composites, suitable for application as refractory materials, from compositions incorporating kaolin wastes together with talc and magnesium hydroxide wastes. All the synthesized materials included quartz, cristobalite, cordierite, spinel $\left(\mathrm{MgO} \cdot \mathrm{Al}_{2} \mathrm{O}_{3}\right)$, sapphirine $\left(\mathrm{Mg}_{4}\left(\mathrm{Mg}_{3} \mathrm{Al}_{9}\right) \mathrm{O}_{4}\left[\mathrm{Si}_{3} \mathrm{Al}_{9} \mathrm{O}_{36}\right]\right)$ and enstatite $\left(\mathrm{Mg}_{2} \mathrm{Si}_{2} \mathrm{O}_{6}\right)$ as crystalline phases. In addition, magnesia $\left(\mathrm{Mg}(\mathrm{OH})_{2}\right)$ was also detected in fired materials where magnesium hydroxide was included in the raw material mixture. The results indicated a higher mullite development in compositions with greater percentage of fine kaolin residue and a higher $\mathrm{Al}_{2} \mathrm{O}_{3} / \mathrm{SiO}_{2}$ ratio. The high fine kaolin residue content also resulted in increased shrinkage during firing, which was attributed to the higher proportion of kaolinite in the initial compositions, and a lower coefficient of thermal expansion.

\subsection{Granitic Sand Washing Waste}

Raigón-Pichardo et al. [139] reported the use of a waste from the beneficiation of tinbearing granitic sands, for use either in the manufacture of ornamental tiles and stoneware products, or in the production of porous tiles or glaze support according to the firing temperature. As a result of the process for the extraction of tin from these sands, a slurry containing a high proportion (75 wt.\%) of tin clay is produced, which consists of $60-50 \%$ kaolinite, $15-20 \%$ potassium mica (illite), $15-20 \%$ quartz and $10-15 \%$ feldspar. Table 18 shows the chemical composition of this waste together with the processing parameters and technological properties of the final ceramic materials.

Table 18. Chemical composition (expressed wt.\% oxide), processing parameters and technological properties of ceramic materials developed from granitic sand washing waste.

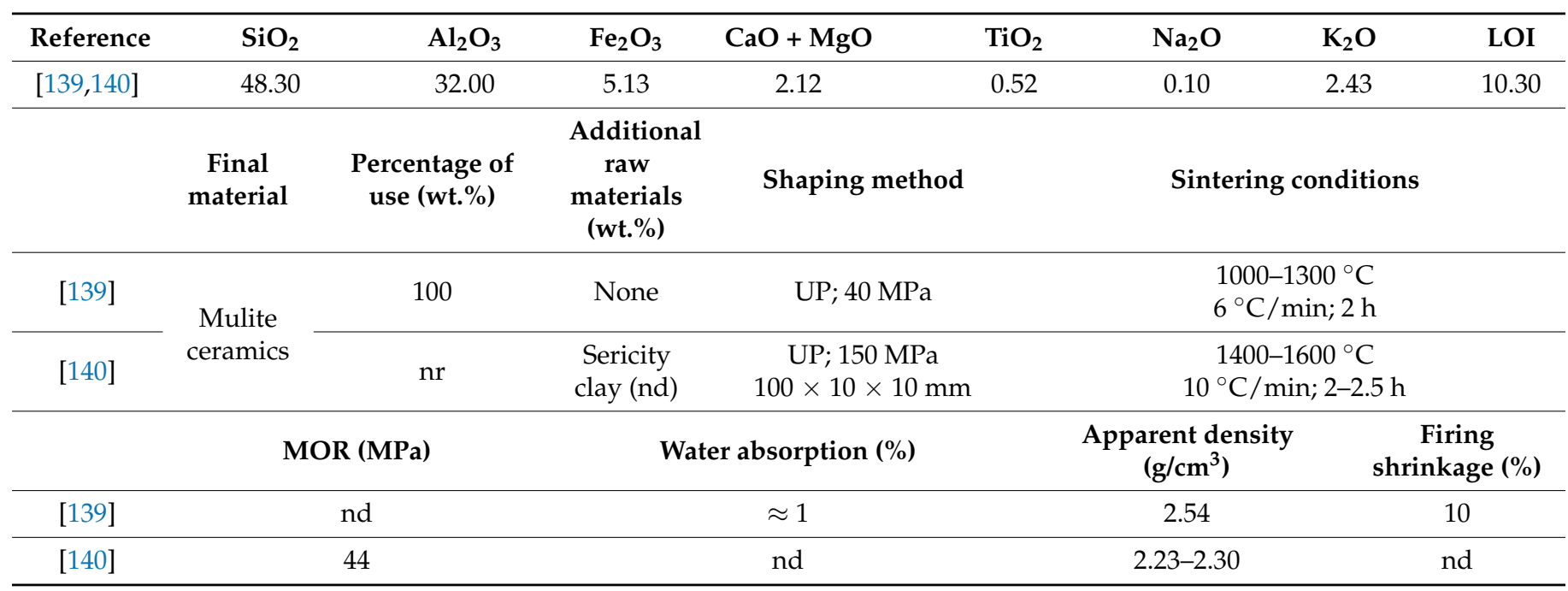

$\mathrm{nd}=$ not determined; $\mathrm{nr}=$ not reported; $\mathrm{UP}=$ uniaxial pressing; $\mathrm{MOR}=$ modulus ofrupture.

The chemical composition of this waste was characterized by a high content of silica and alumina, in agreement with the occurrence of kaolinite and quartz. Furthermore, the chemical analysis also indicated the presence of $\mathrm{K}_{2} \mathrm{O}$ associated with the presence of illite and potassium feldspar and $\mathrm{Fe}_{2} \mathrm{O}_{3}$ related to amorphous iron oxides. The materials resulting from the sintering at temperatures above $1200^{\circ} \mathrm{C}$ were composed of a glassy phase and mullite as the only crystalline phase, with a content of $31 \mathrm{wt} . \%$ in the samples sintered 
at $1300{ }^{\circ} \mathrm{C}$. The materials fired at $1150{ }^{\circ} \mathrm{C}$ showed the highest densification, reaching almost zero water absorption and porosity values. The results highlighted that vitrified ceramics sintered at $1150-1250{ }^{\circ} \mathrm{C}$ were suitable for the manufacture of ornamental tile, stoneware or porcelain stoneware. Moreover, materials prepared at $1000^{\circ} \mathrm{C}$ or lower could be used in the manufacture of porous tiles, with apparent porosity of $\sim 30 \mathrm{vol} \%$, or alternatively as a glaze support.

More recently, Sánchez-Soto et al. [140] examined the effect of the glassy phase on mullite and mullite-based ceramics manufactured from this waste from the beneficiation of granitic sands. On this occasion, the possibility of producing mullite and mullite-based ceramic composites using this residue was investigated by adding powdered $\alpha$-alumina from the manufacture of commercial high alumina refractories, in order to achieve the required mixture to yield the stoichiometry composition of the mullite. The mineralogical analysis showed the disappearance of $\alpha$-alumina and the development of mullite, so that the samples sintered at $1600{ }^{\circ} \mathrm{C}$ consisted of mullite as the single crystalline phase. Microstructural analysis showed the development of well-developed crystals of primary mullite (elongated morphology) and secondary mullite (equiaxed grains), glassy phase and porosity in small proportion. The authors highlighted the impossibility of achieving fully dense mullite materials, even at the sintering temperature of $1600{ }^{\circ} \mathrm{C}$, where a bulk density of $2.30 \mathrm{gmL}^{-1}$ was reached, corresponding to $74 \%$ of the theoretical density of mullite $\left(3.17 \mathrm{gmL}^{-1}\right)$. The authors pointed out that these materials could have potential applications as refractories, ceramic substrates, catalytic supports, filters, etc.

\subsection{Ornamental Rock Waste}

From the beginning of the civilization, ornamental rocks were used both as construction materials and as attractive constituents. These rocks are divided roughly into two main categories, i.e., "ornamental rocks", which are applied with surface polish, as granite and marble; and "semi-ornamental rocks", which are used without polishing, as basalt. The ornamental industry uses a wide variety of rocks, such as agate, gneiss, granite, granodiorite, marble, quartzite, rhyolite or varvite, which are sawed into the desired forms and dimensions. Alves et al. [141] estimated that near $50 \%$ of the ornamental rock extracted corresponds to wastes originated during block sawing. As a result, huge amounts of residues are generated worldwide and damped near the natural stone sawmills without any potential application, which causes environmental implications. A summary of the studies aimed to the synthesis of mullite-based ceramics from ornamental rocks quarrying and cutting waste is given below. Tables 19-29 show the chemical composition of ornamental rock waste, processing parameters and technological properties of the ceramic materials developed.

Table 19. Chemical composition (expressed wt.\% oxide) of granite waste.

\begin{tabular}{|c|c|c|c|c|c|c|c|c|c|c|c|c|}
\hline Reference & Waste & $\mathrm{SiO}_{2}$ & $\mathrm{Al}_{2} \mathrm{O}_{3}$ & $\mathrm{Fe}_{2} \mathrm{O}_{3}$ & $\mathrm{CaO}$ & $\mathrm{MgO}$ & $\mathrm{Na}_{2} \mathrm{O}$ & $\mathrm{K}_{2} \mathrm{O}$ & $\mathrm{TiO}_{2}$ & $\mathrm{P}_{2} \mathrm{O}_{5}$ & $\mathrm{MnO}$ & LOI \\
\hline [142] & Granite waste & 64.14 & 13.25 & 8.18 & 3.56 & 1.65 & 2.55 & 4.40 & 0.96 & nd & nd & 1.60 \\
\hline [143] & Granite waste & 67.14 & 14.92 & 4.40 & 1.91 & 0.73 & 2.93 & 5.18 & 0.73 & nd & nd & 0.50 \\
\hline [144] & Granite sludge & 71.65 & 14.25 & 2.86 & 1.83 & 0.86 & 3.72 & 4.43 & 0.24 & 0.13 & 0.03 & 1.00 \\
\hline [145] & Granite sludge & 67.09 & 13.73 & 2.26 & 4.16 & 0.81 & 3.50 & 4.62 & 0.24 & 0.28 & 0.04 & 3.00 \\
\hline [146] & Granite waste & 57.38 & 16.87 & 7.36 & 5.69 & 2.60 & 3.48 & 3.24 & 0.71 & nd & nd & 2.67 \\
\hline [147] & Granitic waste & 70.70 & 13.91 & 3.77 & 0.94 & 0.08 & 3.37 & 6.25 & 0.45 & 0.05 & 0.10 & 0.40 \\
\hline [148] & Granitic waste & 51.92 & 17.37 & 10.70 & 9.73 & 2.66 & nd & 4.35 & 2.40 & nd & 0.22 & nd \\
\hline [149] & $\begin{array}{c}\text { Granite cutting } \\
\text { sludge }\end{array}$ & $70.03 *$ & $12.68^{*}$ & $6.40 *$ & $1.88^{*}$ & 0.08 * & 3.23 * & 4.53 * & 0.12 * & 0.14 * & $0.08 *$ & nd \\
\hline
\end{tabular}


Table 20. Experimental conditions used in the development of mullite-based materials from granite waste.

\begin{tabular}{|c|c|c|c|c|}
\hline Reference & $\begin{array}{l}\text { Percentage of Use } \\
\text { (wt.\%) }\end{array}$ & $\begin{array}{l}\text { Additional Raw } \\
\text { Materials (wt.\%) }\end{array}$ & Shaping Method & Sintering Conditions \\
\hline [142] & $20-40$ & $\begin{array}{c}\text { Preta clay (25-70) } \\
\text { Carolinho clay }(15-80)\end{array}$ & $\begin{array}{c}\text { Extrusion } \\
100 \times 11 \times 30 \mathrm{~mm}\end{array}$ & $\begin{array}{c}850-1100{ }^{\circ} \mathrm{C} \\
4{ }^{\circ} \mathrm{C} / \mathrm{min} ; 3 \mathrm{~h}\end{array}$ \\
\hline [143] & $10-40$ & Clay (60-90) & $\begin{array}{c}\text { Extrusion } \\
100 \times 15 \times 25 \mathrm{~mm}\end{array}$ & $\begin{array}{c}970{ }^{\circ} \mathrm{C} \\
6 \mathrm{~h}\end{array}$ \\
\hline [144] & $20-50$ & $\begin{array}{l}\text { Clay A }(15-25) \\
\text { Clay B }(25-30) \\
\text { Feldspar }(5-30)\end{array}$ & $\begin{array}{c}\mathrm{UP} ; 47 \mathrm{MPa} \\
\varnothing 20 \times 2 \mathrm{~mm} \\
\text { Extrusion } \\
\varnothing 10 \times 120 \mathrm{~mm}\end{array}$ & $\begin{array}{l}1140-1200{ }^{\circ} \mathrm{C} \\
5^{\circ} \mathrm{C} / \mathrm{min} ; 1 \mathrm{~h}\end{array}$ \\
\hline [145] & $35-70$ & $\begin{array}{c}\text { Clay (48.72) } \\
\text { Quartz (6.28) } \\
\text { Feldspar }(20-45)\end{array}$ & $\begin{array}{c}\text { Extrusion } \\
\varnothing 10 \times 120 \mathrm{~mm}\end{array}$ & $1100-1200{ }^{\circ} \mathrm{C}$ \\
\hline [146] & $2.5-10$ & $\begin{array}{l}\text { Standard porcelain tile } \\
\text { formulation }\end{array}$ & $\mathrm{UP} ; 45 \mathrm{MPa}$ & $\begin{array}{l}1180-1210^{\circ} \mathrm{C} \\
50 \mathrm{~min}\end{array}$ \\
\hline [147] & $25-30$ & $\begin{array}{c}\text { Kaolin (60) } \\
\text { Quartz (10-15) } \\
\text { Feldspar (25) }\end{array}$ & $\begin{array}{c}\mathrm{UP} ; 20 \mathrm{MPa} \\
\varnothing 25 \times 5 \mathrm{~mm} \\
50 \times 10 \times 10 \mathrm{~mm}\end{array}$ & $\begin{array}{l}1000-1350{ }^{\circ} \mathrm{C} \\
5^{\circ} \mathrm{C} / \mathrm{min} ; 2 \mathrm{~h}\end{array}$ \\
\hline [148] & $10-30$ & $\begin{array}{c}\text { Alumina(65-85) } \\
\mathrm{MnO}_{2}(5)\end{array}$ & $\begin{array}{c}\mathrm{UP} ; 20 \mathrm{MPa} \\
50 \times 4 \times 4 \mathrm{~mm}\end{array}$ & $\begin{array}{l}1300-1350{ }^{\circ} \mathrm{C} \\
5^{\circ} \mathrm{C} / \mathrm{min} ; 1 \mathrm{~h}\end{array}$ \\
\hline [149] & $5-10$ & $\begin{array}{c}\text { Feldspar (30-40) } \\
\text { Clay (40) } \\
\text { Quartz (20) } \\
\text { Incinerator fly ash } \\
(5-10)\end{array}$ & $\begin{array}{l}\mathrm{UP} ; 40 \mathrm{MPa} \\
\varnothing 20 \times 5 \mathrm{~mm}\end{array}$ & $\begin{array}{c}1200-1230{ }^{\circ} \mathrm{C} \\
50^{\circ} \mathrm{C} / \mathrm{min} ; 5 \mathrm{~min}\end{array}$ \\
\hline
\end{tabular}

Table 21. Technological properties of mullite-based materials developed from granite waste.

\begin{tabular}{|c|c|c|c|c|c|c|}
\hline Reference & Final Material & $\begin{array}{l}\text { Compressive } \\
\text { Strength } \\
(\mathrm{MPa})\end{array}$ & $\begin{array}{c}\text { Flexural } \\
\text { Strength (MPa) }\end{array}$ & $\begin{array}{c}\text { Water } \\
\text { Absorption (\%) }\end{array}$ & $\begin{array}{c}\text { Apparent } \\
\text { Density }\left(\mathrm{g} / \mathrm{cm}^{3}\right)\end{array}$ & $\begin{array}{c}\text { Firing } \\
\text { Shrinkage (\%) }\end{array}$ \\
\hline [142] & Roofing tile & nd & $4.00-16.0$ & $7.05-23.10$ & $1.77-1.80$ & $1.68-12.07$ \\
\hline [143] & Red ceramic & nd & $8.55-9.60$ & $18.75-23.75$ & $1.67-1.78$ & $2.75-3.29$ \\
\hline [144] & $\begin{array}{l}\text { Porcelain } \\
\text { materials }\end{array}$ & nd & $47.84-60.26$ & $\begin{array}{l}\text { Pellets (0.12-2.23); } \\
\text { Discs (0.07-1.31) }\end{array}$ & $2.20-227$ & $5.56-7.13$ \\
\hline [145] & $\begin{array}{c}\text { Rustic } \\
\text { stoneware }\end{array}$ & nd & $62.10-72.50$ & $0.05-8.80$ & $1.91-2.32$ & nd \\
\hline [146] & $\begin{array}{l}\text { Porcelain } \\
\text { materials }\end{array}$ & nd & nd & $0.50-1.10$ & nd & $7.35-8.25$ \\
\hline [147] & $\begin{array}{l}\text { Porcelain } \\
\text { materials }\end{array}$ & nd & $31.10-45.40$ & $\begin{array}{c}\text { Discs }(0.10-18.30) \\
\text { bars }(0.47-1.40)\end{array}$ & $\begin{array}{c}\text { Discs }(1.83-25.20) \\
\text { bars }(2.31-2.51)\end{array}$ & nd \\
\hline [148] & $\begin{array}{l}\text { Alumina } \\
\text { porcelain }\end{array}$ & nd & $60.50-199.80$ & nd & $2.22-3.18$ & nd \\
\hline [149] & $\begin{array}{l}\text { Porcelainized } \\
\text { stoneware }\end{array}$ & $106-227$ & nd & $0.01-21.90$ & $2.13-2.73$ & $2.51-13.10$ \\
\hline
\end{tabular}


Table 22. Chemical composition (expressed wt.\% oxide), processing parameters and technological properties of ceramic materials developed from marble waste.

\begin{tabular}{|c|c|c|c|c|c|c|c|c|c|c|c|}
\hline Reference & $\mathrm{SiO}_{2}$ & $\mathrm{Al}_{2} \mathrm{O}_{3}$ & $\mathrm{Fe}_{2} \mathrm{O}_{3}$ & $\mathrm{CaO}$ & $\mathrm{MgO}$ & $\mathrm{Na}_{2} \mathrm{O}$ & $\mathrm{K}_{2} \mathrm{O}$ & $\mathrm{TiO}_{2}$ & $\mathrm{P}_{2} \mathrm{O}_{5}$ & $\mathrm{MnO}$ & LOI \\
\hline [150] & 47.93 & 12.62 & 2.97 & 12.58 & 4.90 & 2.27 & 2.33 & 0.45 & 0.27 & 0.05 & 13.11 \\
\hline \multirow[t]{2}{*}{ [151] } & 0.52 & nd & 0.10 & 53.51 & 1.66 & 0.09 & nd & nd & nd & nd & 44.12 \\
\hline & \multicolumn{2}{|c|}{ Final material } & \multicolumn{2}{|c|}{$\begin{array}{c}\text { Percentage of use } \\
\text { (wt.\%) }\end{array}$} & \multicolumn{2}{|c|}{$\begin{array}{l}\text { Additional raw } \\
\text { materials (wt.\%) }\end{array}$} & \multicolumn{2}{|c|}{ Shaping method } & \multicolumn{3}{|c|}{ Sintering conditions } \\
\hline [150] & \multicolumn{2}{|c|}{$\begin{array}{l}\text { Floor red-clay } \\
\text { ceramics }\end{array}$} & \multicolumn{2}{|c|}{$10-30$} & \multicolumn{2}{|c|}{ Red clay (70-90) } & \multicolumn{2}{|c|}{$\begin{array}{c}\mathrm{UP} ; 20 \mathrm{MPa} \\
50 \times 4 \times 4 \mathrm{~mm}\end{array}$} & \multicolumn{3}{|c|}{$\begin{array}{c}1100-1150{ }^{\circ} \mathrm{C} \\
8.33^{\circ} \mathrm{C} / \mathrm{min} ; 2 \mathrm{~h}\end{array}$} \\
\hline \multirow[t]{2}{*}{ [151] } & \multicolumn{2}{|c|}{ Artistic stoneware } & \multicolumn{2}{|c|}{$10-27$} & \multicolumn{2}{|c|}{$\begin{array}{c}\text { Feldspar (23) } \\
\text { Clay (50) } \\
\text { Quartz (0-7) } \\
\text { Kaolin }(0-20)\end{array}$} & \multicolumn{2}{|c|}{$\begin{array}{c}\text { Slip casting } \\
200 \times 20 \times 15 \mathrm{~mm}\end{array}$} & \multicolumn{3}{|c|}{$\begin{array}{c}1160^{\circ} \mathrm{C} \\
7 \mathrm{~h}\end{array}$} \\
\hline & \multicolumn{2}{|c|}{$\begin{array}{l}\text { Flexural strength } \\
(\mathrm{MPa})\end{array}$} & \multicolumn{2}{|c|}{$\begin{array}{c}\text { Water absorption } \\
(\%)\end{array}$} & \multicolumn{2}{|c|}{$\begin{array}{l}\text { Apparent density } \\
\left(\mathrm{g} / \mathrm{cm}^{3}\right)\end{array}$} & \multicolumn{5}{|c|}{ Firing shrinkage (\%) } \\
\hline [150] & \multicolumn{2}{|c|}{$11.23-22.60$} & \multicolumn{2}{|c|}{$3.00-9.80$} & \multicolumn{2}{|c|}{$2.36-2.53$} & \multicolumn{5}{|c|}{$2.05-4.60$} \\
\hline [151] & \multicolumn{2}{|c|}{ nd } & \multicolumn{2}{|c|}{$6.60-14.50$} & \multicolumn{2}{|c|}{ nd } & \multicolumn{5}{|c|}{$4.60-9.60$} \\
\hline
\end{tabular}

Table 23. Chemical composition (expressed wt.\% oxide) of quartz and quartzite waste.

\begin{tabular}{|c|c|c|c|c|c|c|c|c|c|c|c|c|}
\hline Reference & Waste & $\mathrm{SiO}_{2}$ & $\mathrm{Al}_{2} \mathrm{O}_{3}$ & $\mathrm{Fe}_{2} \mathrm{O}_{3}$ & $\mathrm{CaO}$ & $\mathrm{MgO}$ & $\mathrm{Na}_{2} \mathrm{O}$ & $\mathrm{K}_{2} \mathrm{O}$ & $\mathrm{TiO}_{2}$ & $\mathbf{P}_{2} \mathbf{O}_{5}$ & $\mathrm{MnO}$ & LOI \\
\hline [106] & $\begin{array}{l}\text { Quartz } \\
\text { tailing }\end{array}$ & 89.8 & 5.16 & 0.57 & 0.04 & 0.11 & 0.11 & 1.20 & nd & nd & nd & nd \\
\hline [144] & $\begin{array}{c}\text { Quartzite } \\
\text { waste }\end{array}$ & 68.48 & 14.93 & 4.68 & 0.11 & 0.78 & 0.31 & 2.94 & 1.08 & 0.21 & 0.07 & 5.50 \\
\hline [152] & $\begin{array}{l}\text { Quartzite } \\
\text { waste }\end{array}$ & 94.14 & 2.15 & 0.23 & nd & 0.01 & nd & 0.26 & nd & nd & nd & 0.54 \\
\hline [153] & $\begin{array}{c}\text { Quartzite } \\
\text { waste }\end{array}$ & 78.15 & 11.39 & 5.11 & 0.90 & 0.86 & nd & 5.11 & 0.13 & nd & nd & 1.53 \\
\hline [154] & $\begin{array}{c}\text { Quartzite } \\
\text { waste }\end{array}$ & 67.71 & 18.50 & 1.96 & 1.23 & 1.78 & nd & 7.80 & 0.22 & nd & nd & nd \\
\hline [155] & $\begin{array}{c}\text { Quartzite } \\
\text { waste }\end{array}$ & 77.1 & 11.2 & 1.4 & 0.9 & 0.9 & nd & 5.0 & 0.1 & nd & nd & 2.9 \\
\hline
\end{tabular}


Table 24. Experimental conditions used in the development of mullite-based materials from quartz and quartzite waste.

\begin{tabular}{|c|c|c|c|c|}
\hline Reference & Percentage of Use (wt.\%) & Additional Raw Materials (wt.\%) & Shaping Method & Sintering Conditions \\
\hline [106] & $28.8-82.0$ & $\mathrm{AlO}(\mathrm{OH})(18.0-71.2)$ & $\begin{array}{c}\mathrm{UP} ; 25 \mathrm{MPa} \\
\varnothing 20 \times 3 \mathrm{~mm}\end{array}$ & $\begin{array}{c}1300^{\circ} \mathrm{C} \\
3.3^{\circ} \mathrm{C} / \mathrm{min} ; 3 \mathrm{~h}\end{array}$ \\
\hline [144] & $35-70$ & $\begin{array}{c}\text { Clay (48.72) } \\
\text { Quartz (6.28) } \\
\text { Feldspar (20-45) }\end{array}$ & $\begin{array}{c}\text { Extrusion } \\
\varnothing 10 \times 120 \mathrm{~mm}\end{array}$ & $1100-1200{ }^{\circ} \mathrm{C}$ \\
\hline [152] & $10-15$ & Red clay (85-90) & $\begin{array}{c}\mathrm{UP} ; 28-35 \mathrm{MPa} \\
70 \times 20 \times 10 \mathrm{~mm}\end{array}$ & $\begin{array}{c}950-1100{ }^{\circ} \mathrm{C} \\
5^{\circ} \mathrm{C} / \mathrm{min} ; 2 \mathrm{~h}\end{array}$ \\
\hline [153] & $10-25$ & Red clay (75-90) & $\begin{array}{c}\mathrm{UP} ; 20 \mathrm{MPa} \\
50 \times 15 \times 10 \mathrm{~mm}\end{array}$ & $\begin{array}{c}800-1000{ }^{\circ} \mathrm{C} \\
2{ }^{\circ} \mathrm{C} / \mathrm{min} ; 3 \mathrm{~h}\end{array}$ \\
\hline [154] & $1.76-10.24$ & Ceramic mass for porcelain & $\begin{array}{c}\mathrm{UP} ; 50 \mathrm{MPa} \\
20 \times 7 \times 60 \mathrm{~mm}\end{array}$ & $\begin{array}{c}1143-1257^{\circ} \mathrm{C} \\
49^{\circ} \mathrm{C} / \mathrm{min} ; 2 \mathrm{~h}\end{array}$ \\
\hline [155] & $10-25$ & $\begin{array}{c}\text { Clay (48.72) } \\
\text { Quartz (6.28) } \\
\text { Feldspar }(20-45)\end{array}$ & $\begin{array}{c}\text { Slip casting } \\
6.0 \times 2.0 \times 0.5 \mathrm{~mm}\end{array}$ & $\begin{array}{c}600-1200{ }^{\circ} \mathrm{C} \\
2-4{ }^{\circ} \mathrm{C} / \mathrm{min} ; 40 \mathrm{~min}\end{array}$ \\
\hline [156] & $3.0-12.0$ & $\begin{array}{c}\text { Clay UKR (22.0) } \\
\text { Clay } 1(8.5) \\
\text { Clay } 2(6.0) \\
\text { Pegmatite (34.5) } \\
\text { Magnesite (2.0) } \\
\text { Albite (15-27) }\end{array}$ & $\mathrm{UP} ; 30 \mathrm{MPa}$ & $\begin{array}{l}1200{ }^{\circ} \mathrm{C} \\
30 \mathrm{~min}\end{array}$ \\
\hline
\end{tabular}

Table 25. Technological properties of mullite-based materials developed from quartz and quartzite waste.

\begin{tabular}{ccccccc}
\hline Reference & Final Material & $\begin{array}{c}\text { Compressive } \\
\text { Strength } \\
\text { (MPa) }\end{array}$ & $\begin{array}{c}\text { Flexural } \\
\text { Strength (MPa) }\end{array}$ & $\begin{array}{c}\text { Water } \\
\text { Absorption (\%) }\end{array}$ & $\begin{array}{c}\text { Apparent } \\
\text { Density } \\
\left(\mathbf{g} / \mathbf{c m}^{\mathbf{3}}\right)\end{array}$ & $\begin{array}{c}\text { Firing } \\
\text { Shrinkage (\%) }\end{array}$ \\
\hline$[106]$ & Mullite ceramic & nd & nd & nd & 2.4 & nd \\
{$[145]$} & Rustic & nd & $27.80-30.75$ & $3.90-14.10$ & $2.00-2.25$ & nd \\
{$[152]$} & $\begin{array}{c}\text { Reneware } \\
\text { Structural } \\
\text { ceramic }\end{array}$ & $34.67-192.56$ & $1.56-2.58$ & $1.43-11.37$ & nd & $11.84-24.58$ \\
{$[153]$} & $\begin{array}{c}\text { Porcelain } \\
\text { material }\end{array}$ & nd & $1.38-6.52$ & $13.80-19.05$ & nd & $0.01-3.25$ \\
{$[154]$} & Sanitary ware & nd & $21.18-71.52$ & $0.00-12.68$ & $1.93-2.42$ & $3.34-8.68$ \\
{$[155]$} & & & $27.50-46.40$ & $0.50-0.90$ & $2.30-2.40$ & $9.80-11.80$ \\
\hline
\end{tabular}

nd $=$ not determined.

Table 26. Chemical composition (expressed wt.\% oxide), processing parameters and technological properties of ceramic materials developed from agate waste.

\begin{tabular}{|c|c|c|c|c|c|c|c|c|c|}
\hline Reference & $\mathrm{SiO}_{2}$ & $\mathrm{Al}_{2} \mathrm{O}_{3}$ & $\mathrm{Fe}_{2} \mathrm{O}_{3}$ & $\mathrm{CaO}$ & $\mathrm{MgO}$ & $\mathrm{Na}_{2} \mathrm{O}$ & $\mathrm{K}_{2} \mathrm{O}$ & $\mathrm{TiO}_{2}$ & LOI \\
\hline \multirow{5}{*}{ [156] } & 98.46 & 0.21 & 0.02 & 0.05 & 0.02 & 0.09 & 0.01 & 0.01 & 1.13 \\
\hline & \multicolumn{2}{|c|}{ Final material } & \multicolumn{2}{|c|}{$\begin{array}{c}\text { Percentage of use } \\
(w \mathrm{t} \%)\end{array}$} & \multicolumn{2}{|c|}{$\begin{array}{l}\text { Additional raw } \\
\text { materials (wt.\%) }\end{array}$} & $\begin{array}{l}\text { Shaping } \\
\text { method }\end{array}$ & \multicolumn{2}{|c|}{ Sintering conditions } \\
\hline & \multicolumn{2}{|c|}{ Porcelain material } & \multicolumn{2}{|c|}{$15-65$} & $\begin{array}{r}\text { Kao } \\
\text { Felds }\end{array}$ & $\begin{array}{l}-70) \\
5-65)\end{array}$ & $\begin{array}{c}\mathrm{UP} ; 40 \\
\mathrm{MPa} \\
70 \times 25 \times \\
5 \mathrm{~mm}\end{array}$ & \multicolumn{2}{|c|}{$\begin{array}{c}1180{ }^{\circ} \mathrm{C} \\
5^{\circ} \mathrm{C} / \mathrm{min} ; 1 \mathrm{~h}\end{array}$} \\
\hline & \multicolumn{2}{|c|}{$\begin{array}{c}\text { Flexural strength } \\
\text { (MPa) }\end{array}$} & \multicolumn{2}{|c|}{ Water absorption (\%) } & \multicolumn{3}{|c|}{ Apparent density $\left(\mathrm{g} / \mathrm{cm}^{3}\right)$} & \multicolumn{2}{|c|}{ Firing shrinkage (\%) } \\
\hline & \multicolumn{2}{|c|}{$12.69-57.98$} & \multicolumn{2}{|c|}{$0.13-15.37$} & \multicolumn{3}{|c|}{$1.75-2.33$} & \multicolumn{2}{|c|}{$2.29-13.62$} \\
\hline
\end{tabular}


Table 27. Chemical composition (expressed wt.\% oxide), processing parameters and technological properties of ceramic materials developed from gneiss and varvite waste.

\begin{tabular}{|c|c|c|c|c|c|c|c|c|c|c|c|c|}
\hline Reference & Waste & $\mathrm{SiO}_{2}$ & $\mathrm{Al}_{2} \mathrm{O}_{3}$ & $\mathrm{Fe}_{2} \mathrm{O}_{3}$ & $\mathrm{CaO}$ & $\mathrm{MgO}$ & $\mathrm{Na}_{2} \mathrm{O}$ & $\mathrm{K}_{2} \mathrm{O}$ & $\mathrm{TiO}_{2}$ & $\mathbf{P}_{25}$ & $\mathrm{MnO}$ & LOI \\
\hline$[157]$ & Gneiss & 59.22 & 16.75 & 4.56 & 5.98 & 1.63 & 4.48 & 4.31 & 0.43 & 0.75 & 0.14 & 1.74 \\
\hline [157] & Varvite & 74.32 & 8.79 & 2.43 & 2.68 & 1.74 & 3.12 & 1.48 & 0.51 & 0.18 & 0.16 & 4.59 \\
\hline [158] & Gneiss & 67.83 & 14.76 & 1.44 & 0.29 & 0.39 & 0.34 & 3.26 & 1.68 & nd & nd & 0.66 \\
\hline & \multicolumn{3}{|c|}{ Final material } & \multicolumn{3}{|c|}{ Percentage of use (wt.\%) } & \multicolumn{2}{|c|}{$\begin{array}{c}\text { Additional raw } \\
\text { materials } \\
\text { (wt.\%) }\end{array}$} & \multicolumn{2}{|c|}{$\begin{array}{l}\text { Shaping } \\
\text { method }\end{array}$} & \multicolumn{2}{|c|}{$\begin{array}{l}\text { Sintering } \\
\text { conditions }\end{array}$} \\
\hline [157] & \multicolumn{3}{|c|}{ Porcelain material } & \multicolumn{3}{|c|}{$\begin{array}{l}\text { Gneiss (5-45) } \\
\text { Varvite (5-65) }\end{array}$} & \multicolumn{2}{|c|}{$\begin{array}{l}\text { Residual clay } \\
\quad(20-40) \\
\text { Potable water } \\
\text { sludge (10-65) }\end{array}$} & \multicolumn{2}{|c|}{$\begin{array}{c}\mathrm{UP} ; 50 \mathrm{MPa} \\
\varnothing 25 \times 10 \mathrm{~mm} \\
60 \times 20 \times 10 \\
\mathrm{~mm}\end{array}$} & \multicolumn{2}{|c|}{ 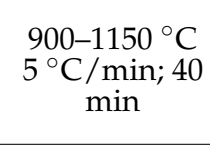 } \\
\hline \multirow[t]{2}{*}{ [158] } & \multicolumn{3}{|c|}{ Electric porcelain } & \multicolumn{3}{|c|}{ Gneiss (40-60) } & \multicolumn{2}{|c|}{$\begin{array}{l}\text { Kaolinitic clay } \\
\quad(40-60)\end{array}$} & \multicolumn{2}{|c|}{$\begin{array}{c}\mathrm{UP} ; 30 \mathrm{MPa} \\
114.5 \times 25.4 \times 8 \\
\mathrm{~mm}\end{array}$} & \multicolumn{2}{|c|}{$\begin{array}{l}1200^{\circ} \mathrm{C} \\
15 \mathrm{~min}\end{array}$} \\
\hline & \multicolumn{3}{|c|}{ Flexural strength (MPa) } & \multicolumn{3}{|c|}{ Water absorption (\%) } & \multicolumn{4}{|c|}{ Apparent density $\left(\mathrm{g} / \mathrm{cm}^{3}\right)$} & \multicolumn{2}{|c|}{$\begin{array}{c}\text { Firing } \\
\text { shrinkage (\%) }\end{array}$} \\
\hline [157] & \multicolumn{3}{|c|}{$0.75-3.8$} & \multicolumn{3}{|c|}{$0.35-21.05$} & \multicolumn{4}{|c|}{$2.20-2.75$} & \multicolumn{2}{|c|}{$2.00-11.90$} \\
\hline [158] & \multicolumn{3}{|c|}{$\sim 40-55$} & \multicolumn{3}{|c|}{$0.1-0.6$} & \multicolumn{4}{|c|}{$\mathrm{nr}$} & \multicolumn{2}{|c|}{$\mathrm{nr}$} \\
\hline
\end{tabular}

$\mathrm{nd}=$ not determined; $\mathrm{nr}=$ not reported; $\mathrm{UP}=$ uniaxial pressing.

\subsubsection{Granitic Rock Waste}

Granite is a light-colored igneous rock. It is the most common type of igneous rock in the Earth's crust and ocean floor. It consists mostly of coarse-grained quartz and feldspar and also small amounts of minerals belonging to mica and amphibole groups.

Monteiro et al. [142] evaluated manufacture of roofing ceramic tiles from a granite waste sludge produced during sawing operations. The granite waste was composed mainly by $\mathrm{SiO}_{2}$ and $\mathrm{Al}_{2} \mathrm{O}_{3}$ and also showed a significant presence of alkaline and alkaline earth oxides. Quartz, mica, plagioclase and microcline being the constituent crystalline phases in this waste. Different composition for roofing tiles were formulated by the replacement of natural sand by the granite waste. The finer particle size of the waste limited the possibility of shrinkage cracks and promoted the quartz dissolution on firing. In addition, the granite residue contained alkaline fluxes, which promoted the formation of liquid phases and favored the removal of porosity. The sintering of mixtures of granite waste and two different clays resulted in materials comprising quartz, mullite and plagioclase as main crystalline phases. According to results, the drying linear shrinkage of the ceramic bodies was reduced with the incorporation of granite waste. Moreover, the specimens exhibited higher flexural strength (up to $16 \mathrm{MPa}$ ) and lower water absorption values than the commercial specimen used as control.

In the same way, Vieira et al. [143] reported the effect of incorporating granite waste into a red ceramic body. Mixtures of powder granite waste (0-40 wt.\%) and clay led to sintered ceramics consisted of mullite, plagioclase, quartz, potassium feldspar and a micaceous mineral. The authors noted that the addition of granite waste contributed to the formation of residual phases from the feldspar fraction, but it did not affect the formation of mullite from the decomposition of metakaolinite around $970{ }^{\circ} \mathrm{C}$. These results pointed out that the incorporation of powder granite waste into red ceramic bodies improved the technological properties because the porosity and water absorption were reduced while flexural strength values were similar to the control specimen.

Torres et al. [144] included different amounts of granite cutting sludge into a clayey body for porcelain tiles. The authors substituted the maximum amount of feldspar by sludge. The results suggested that the addition of granite sludge presumably acted by reducing the open porosity, which resulted in a significant improvement in water absorption $(0.07 \%)$ and mechanical strength (above $55 \mathrm{MPa}$ ). On the other hand, the incorporation of granite sludge had a negligible effect on shrinkage, plasticity and density. The authors 
remarked that industrial production of these materials would be possible without costly process modifications. Thereafter, Torres et al. [145] evaluated how the addition of granite cutting reject affected the properties of a rustic clay-based tile. The granite waste consisted of quartz, illite, kaolinite, feldspatic minerals and traces of calcite, probably derived from the polishing equipment. Different mixtures of red clay, quartz and feldspar, replaced by granite sludge, derived in ceramic containing mullite, quartz, anorthite and hematite. The granite waste addition improved the properties of sintered red ceramics by reducing water absorption values while keeping flexural strength increased widely, even at low firing temperatures, in comparison to the reference paste. The new products fulfilled the most demanding requirements of the ISO 13006 standard [146], group BIa (porcelain tiles) in relation to water absorption (near zero) and flexural strength $(72.5 \mathrm{MPa})$.

Recent research conducted by Pazniak et al. [147] combined fast firing cycles at high temperature in order to obtain porcelain stoneware with granitic rock waste as substitute of feldspar. The granite waste was composed of plagioclase (50-60 wt.\%), mica minerals (11-23 wt.\%), amphibole (9-22 wt.\%), quartz (7-12 wt.\%) and feldspar (1-5 wt.\%). Feldspars contained in the waste melted and induced the development of a liquid phase in the $\mathrm{K}_{2} \mathrm{O}-\mathrm{Na}_{2} \mathrm{O}-\mathrm{SiO}_{2}$ system. This phase was enriched with iron oxides, alkaline earth oxides and silica and started to flow at temperatures of $1170-1180{ }^{\circ} \mathrm{C}$. The microstructural analysis of firing tiles revealed the main presence of vitreous phase and quartz, and some small alumina-rich crystals like mullite as the main crystalline phases. The authors highlighted the possibility of manufacturing industrial porcelain tiles as the results revealed high densification and near zero water absorption values. Another example of this type of research is the work developed by El-Maghraby et al. [148], which produced porcelain tiles using granite waste as substitute of feldspar. The waste was composed of a micaceous mineral, quartz, albite and microcline. Batches composition of the porcelain bodies combined kaolin, quartz and granite waste. The findings concluded that adding waste to the body composition resulted in the formation of mullite and an increase in quartz amount. The incorporation of granite waste also decreased the open porosity of the fired bodies. Consequently, the bulk density and flexural strength increased and the water absorption decreased with the granite waste content. The microstructural study revealed that fired materials exhibited a fine fracture surface with few defects and no significant effect on the crystalline phases was observed with granite waste inclusion.

Acchar et al. [149] assessed the utilization of granite reject, alumina and manganese oxide (5 wt. $\% \mathrm{MnO}_{2}$ ) in the production of alumina bodies. The granite reject consisted mainly of $\mathrm{SiO}_{2}, \mathrm{Al}_{2} \mathrm{O}_{3}, \mathrm{Fe}_{2} \mathrm{O}_{3}$ and $\mathrm{CaO}$, with $\mathrm{K}_{2} \mathrm{O}, \mathrm{MgO}$ and $\mathrm{TiO}_{2}$ as minor components. After firing, the major crystalline phases identified in the sintered bodies were alumina, wollastonite and anorthite along with minor phases such as mullite and quartz. The addition of granite waste and $\mathrm{MnO}_{2}$ decreased the open porosity of fired samples, which presented higher apparent density values. The study concluded that the decrease in porosity and the associated densification of the samples lead to higher mechanical strength of samples manufactured from granite waste (increasing from $65 \mathrm{MPa}$ of the control sample to $196 \mathrm{MPa}$ achieved by the specimen with $20 \mathrm{wt}$ \% of rejection content). Therefore, these ceramics could be considered as high resistance ceramic bodies.

Other options available to treat ornamental rock wastes also involve porcelain stoneware tile production using granite waste. Hernández-Crespo and Rincón [150] reported the use of two granite sawing residues as raw material in the production of porcelainized ceramic-based products. The granite residues included $\alpha$-quartz, albite and orthoclase as main mineral phases. In addition, micaceous minerals and a minor occurrence of magnetite (and/or spinels) were also found, which were related to the metallic particles, as well as some calcite from the sawing process. Porcelainized ceramics were prepared by replacement from an adequate porcelain formulation (40\% feldspar, 40\% clay and 20\% quartz) of $10 \mathrm{wt} . \%$ of feldspar by granite waste and 10\% clay by incinerator fly ash of municipal solid waste. The results concluded that the incorporation of granite waste improved the sintering process and reduced the water absorption (near zero). The mineralogical study 
suggested that the viscosity did not undergo the usual reduction with temperature because of the dissolution of quartz and the formation of mullite improved the sintering process. Furthermore, the fired materials showed density and mechanical resistance comparable to those of commercial porcelain ceramics. Considering these results, the authors highlighted that the final materials could be an interesting new type of construction material, with promising applications in this field.

\subsubsection{Marble Waste}

Marble is a metamorphic rock formed when limestone is exposed to heat and pressure. It is majorly composed of carbonate minerals, such as calcite or dolomite, and other minor mineral phases, essentially, quartz, micas, iron oxides, graphite and pyrite.

Segadães et al. [151] assessed the positive effect of adding a mixture of marble and granite rejects from the stone-cutting industry, in the industrial manufacture of red clay stoneware. The main chemical constituents of the stone reject were $\mathrm{SiO}_{2}, \mathrm{Al}_{2} \mathrm{O}_{3}$ and $\mathrm{CaO}$ together with minor amounts of $\mathrm{Fe}_{2} \mathrm{O}_{3}$ and alkaline and alkaline-earth oxides. Ceramic bodies were produced by adding different concentrations of rejects to red clay. After firing, ceramic samples comprised mullite, quartz, anorthite and hematite. The result showed that the addition of marble and granite rejects to red clay stoneware contributed to the development of mullite, which enhanced the technological properties of the fired ceramics, reducing the water absorption index and maintaining the mechanical resistance. The final product could be classified as class IIa according to the requirements of the ISO 13006 standard [146]. The authors concluded that the marble reject content highly influenced the formation of crystalline phases improving the sintering process and the technological properties, even at low firing temperature. This fact would mean energy savings in the red ceramic manufacturing process.

On the other hand, a comprehensive study for evaluating the role of marble waste in traditional artistic stoneware clay body was carried by Yeşilay et al. [152]. Marble waste was composed mainly of $\mathrm{CaO}$ and $\mathrm{MgO}$ and included calcite and dolomite as crystalline components. Batch formulations containing significant amounts of marble powder reject replacing kaolin and quartz in a clay body were studied. The crystalline phases presented in the bodies after firing under industrial conditions were principally quartz, mullite and residual anorthite. The results suggested the relationship between the microstructure of clay and the firing color, although the marble content also affected, darkening the final color. Moreover, the inclusion of marble waste led to stoneware bodies fulfilled the criteria of artwork ceramic, in accordance with plasticity, water absorption, dimensional stability and whiteness (Figure 9).

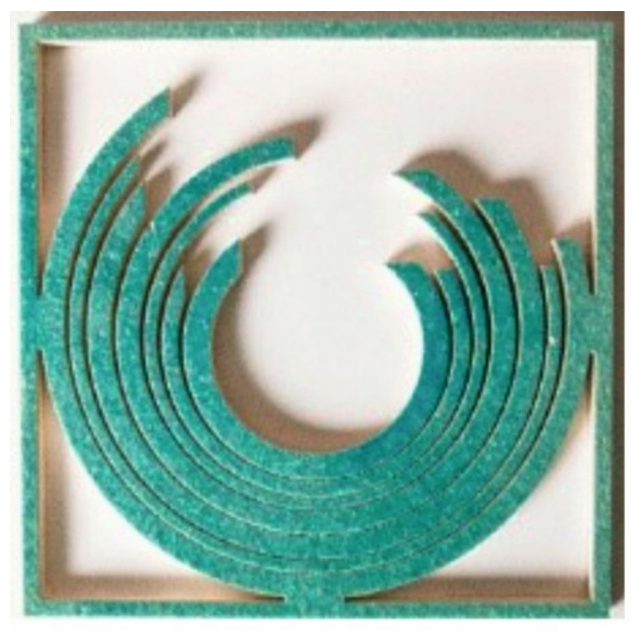

(a)

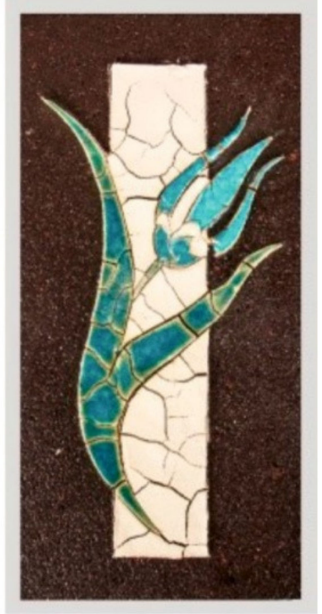

(b)

Figure 9. Artistic ceramics produced from marble waste by (a) pressing and (b) slip casting [152]. 


\subsubsection{Quartz and Quartzite Rock Waste}

Quartz is one of the most useful minerals found in the Earth's crust. Thus, quartz is an indispensable raw material in the manufacture of glass and fiberglass and an important component in the manufacture of rubber, paint and putty. Quartz sand is a very powerful abrasive used for sandblasting, rock cutting, scrubbing cleaners, grinding media and also for sanding and cutting. Little chips of quartz are used in technological devices such as watches, computers, and tablets. Moreover, some types of quartz are considered as semi-precious (citrine or amatiste) or ornamental (jaspe) stones, so they find application in jewelry. Karhu et al. [106] also explored the use of quartz tailings in the preparation of mullite-containing ceramic materials. $\mathrm{SiO}_{2}$ was the principal constituent of quartz tailings, which also included $\mathrm{Al}_{2} \mathrm{O}_{3}$ as a minor component. These tailings consisted of quartz (64 wt.\%) as the main crystalline phase, together with muscovite (27 wt.\%) and kaolinite $(4 \mathrm{wt} . \%)$. Sintering of quartz tailings and boehmite mixtures resulted in crystalline materials with a microstructure mostly comprised of coarse quartz grains together with corundum and isolated acicular mullite crystals in a smaller amount. The authors pointed out that mullite crystals were probably formed from the kaolinite contained in the tailings and to promote further mullite formation by solid state reaction of $\mathrm{SiO}_{2}$ and $\mathrm{Al}_{2} \mathrm{O}_{3}$, it would be necessary to conduct sintering at higher temperatures than those used in this study.

Quartzite is a non-foliated metamorphic rock formed when quartz-rich sandstone or chert is altered by the metamorphism, high temperatures and pressures. Under these conditions, the silica cement and the sand grains produce a reinforced network of interlocking quartz grains (90 wt.\%). A recent work conducted by Silva et al. [153] analyzed the microstructure and technological properties of red ceramic bricks manufactured from clay and sawing quartzite fines in order to evaluate the feasibility of recycling the quartzite waste as ceramic additive. $\mathrm{SiO}_{2}$ was the main component of the quartzite waste whereas quartz together with cianite and muscovite were the constituent crystalline phases. The results suggested that the incorporation up to $15 \mathrm{wt} . \%$ of quartzite waste fired at $1100{ }^{\circ} \mathrm{C}$ and $35 \mathrm{MPa}$ lead to the best settings. The mineralogical results revealed the partial thermal breakdown of the mineral phases with the re-crystallization of mullite and cristobalite. The incorporation of quartzite waste in red clay body production resulted in lower production costs and environmentally friendly products. In a similar study, Carreiro et al. [154] assessed the possibility of recycling quartzite residue in the production of red clay bodies as a raw material for structural ceramic products. Quartzite waste presented $\mathrm{SiO}_{2}$ and $\mathrm{Al}_{2} \mathrm{O}_{3}$ as main constituents and $\mathrm{K}_{2} \mathrm{O}, \mathrm{TiO}_{2}, \mathrm{CaO}, \mathrm{MgO}$ and $\mathrm{Fe}_{2} \mathrm{O}_{3}$ in minor proportion. On the other hand, quartz, mica and feldspar were the crystalline phases presented in the waste. Mixtures of red clay and quartzite were studied and the results concluded that the addition of the residue did not change the coloring characteristics of the pieces after firing. Thus, the reuse of quartzite into red ceramics is an excellent alternative for waste management practices.

Furthermore, Torres et al. [145] replaced different quantities of red clay by quartzite powder in industrial rustic tiles production in a pilot plant. Quartzite was composed of quartz, muscovite, accompanied by clinochlore $\left((\mathrm{Mg}, \mathrm{Fe})_{6}(\mathrm{Si}, \mathrm{Al})_{4} \mathrm{O}_{10}(\mathrm{OH})_{8}\right)$ and microcline. As a result of the incorporation of quartzite in the formulation of rustic bodies, their technological properties were improved. The occurrence of mullite and glassy phase in the fired materials produced a reduction of the apparent density values. In addition, the significant decrease of density at $1200{ }^{\circ} \mathrm{C}$ is mostly the consequence of over-firing phenomena. The water absorption values were lower than $5 \%$ in samples fired at $1200{ }^{\circ} \mathrm{C}$. The open porosity and the bending strength increased compared to reference. Regarding the ISO 13006 standard [146], specimens containing up to $65 \mathrm{wt} . \%$ of quartzite belonged to group BIIa, and sample with $70 \mathrm{wt} . \%$ was classified as Blb. The addition of quartzite had negligible effect on other properties such as plasticity and moreover, no costly modifications will be necessary for industrial production. In a more recent study, Ruiz Silva et al. [155] investigated the use of quartzite residue in commercial porcelain tile. The authors carried out a deep physical-chemical and microstructural analysis in order to comprehend how 
quartzite waste content influenced the properties of green and fired bodies. Thus, quadratic and linear regression analyses correlating quartzite waste content and sintering temperature with the technological properties (linear shrinkage, apparent density, water absorption and flexural strength) were applied. Mineralogical studies suggested that quartz, mullite and anorthite were the major crystalline phases detected. However, anorthite disappeared with sintering temperatures above $1200{ }^{\circ} \mathrm{C}$. Regarding the technological results, similar values were obtained in porcelain bodies containing quartzite residues compared to standard. Moreover, specimens fired at 1240 and $1257^{\circ} \mathrm{C}$ met the requirements established for porcelain stoneware in the ISO 13006 standard (water absorption $<0.5 \%$ and flexural strength $\geq 35 \mathrm{MPa}$ ).

Finally, Soares de Medeiros et al. [156] assessed the addition of quartzite waste to produce sanitary ware. Thus, batch formulations of clay, quartz and quartzite residue as replacement of feldspar were evaluated. The main crystalline phases formed during the sintering process were mullite and quartz. Based on the results, the quartzite waste inclusion in sanitary stoneware produced non-significant effects on the firing shrinkage. However, quartzite incorporation improved the mechanical resistance (above $35 \mathrm{MPa}$ ). Moreover, the addition up to $15 \mathrm{wt} . \%$ of quartzite attended the technical recommendation for sanitary ware ceramics.

\subsubsection{Agate Waste}

Agate is a common semiprecious silica mineral, a variety of chalcedony $\left(\mathrm{SiO}_{2}\right)$ consisting of bands with varying color and transparency. Agates are chiefly formed within igneous and metamorphic rocks. The ornamental use of agate dates back to Ancient Greece. Correia et al. [157] described the use of agate waste as substitute for quartz sand in the production of porcelain stoneware. Different amounts of powdered agate scrap were combined with kaolinitic clay and potassium feldspar and fired at $1180^{\circ} \mathrm{C}$. The mineralogical analysis indicated that quartz and mullite were the main crystalline phases in the fired bodies. In order to achieve the best formulation to produce a porcelain body with specific properties, regression analyses related to the properties of both green and fired ceramic bodies were carried out. The results showed that the range of acceptable values were $15-22$ wt. $\%$ of agate scrap, $25-37$ wt. $\%$ of potassium feldspar and $43-60$ wt. $\%$ of kaolinitic clay. The microstructure of fired materials was composed of undissolved quartz particles and well-interconnected mullite needles dispersed in the amorphous phase (Figure 10). The authors concluded that the agate scrap is feasible for porcelain ceramic tile production.
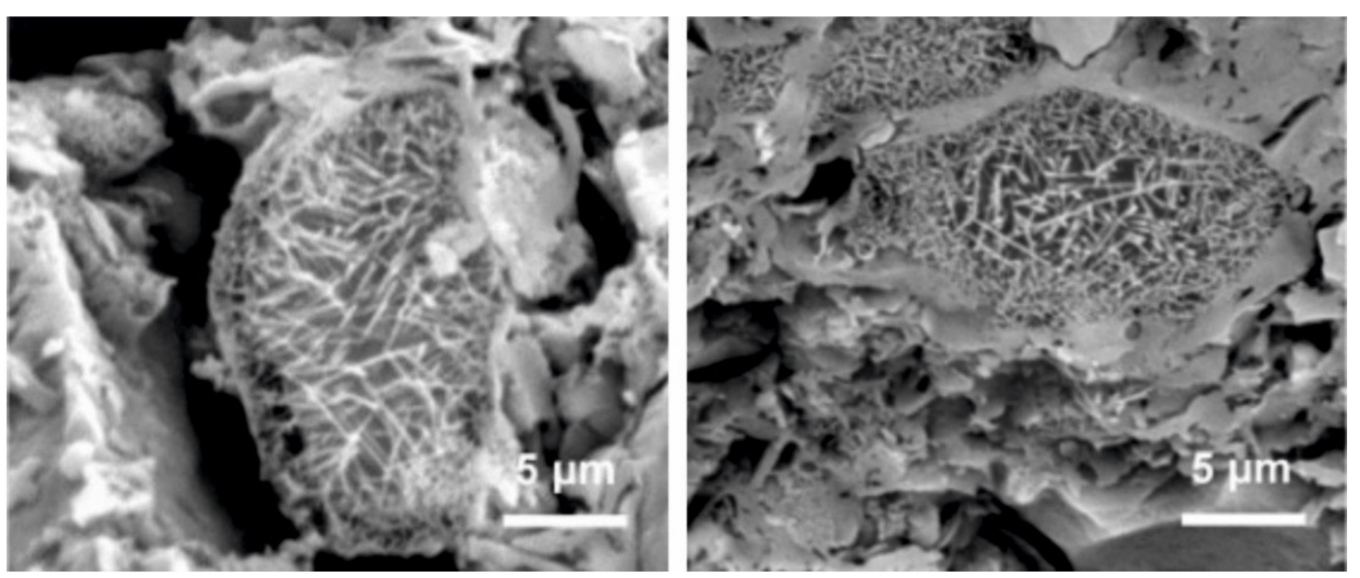

Figure 10. SEM photographs of HF-etched fracture surfaces of fired samples prepared from agate scraps [157].

\subsubsection{Gneiss and Varvite Waste}

Gneiss is a foliated metamorphic rock identified by its bands and layers of varying composition. Bands contain granular minerals with an interlocking texture and other bands 
contain platy or elongate minerals with evidence of preferred orientation. On the other hand, varvite is a singular sedimentary rock whose formation was controlled by the yearly succession of seasonal deposits producing alternately thinner and thicker bands of silt or clay. Junkes et al. [158] studied a new method of manufacturing porcelain ceramics using only waste as gneiss and varvite powders together with sludge from potable water preparation processes (PWS) and clay-based waste as plastic components. The gneiss residue was composed of $\mathrm{SiO}_{2}, \mathrm{Al}_{2} \mathrm{O}_{3}, \mathrm{Fe}_{2} \mathrm{O}_{3}$ and alkaline and alkaline earth oxides, while the varvite mud contained mostly $\mathrm{SiO}_{2}$. As for their mineralogy, the gneiss waste contained quartz, albite and microcline and iron oxides (hematite and magnetite), while quartz, albite and clinochlore were the predominant phases in the varvite waste along with traces of dolomite. According to the leucite-silica-mullite system (Figure 11), four mixtures located in the primary phase field of mullite formation were formulated. After sintering, the materials produced were mainly mullite and quartz, in ratios depending on the raw material composition and firing temperature. Albite, anorthite, enstatite and residual hematite are also present in varying proportions. The results showed low values of water absorption (below 3\%) and flexural strengths ranged between 2.9-3.8 MPa. Moreover, the density values ranged between 2.03 and $2.61 \mathrm{~g} \cdot \mathrm{cm}^{-3}$ for 1100 and $1150{ }^{\circ} \mathrm{C}$, respectively. The study concluded that the technological properties of the fired materials were within the standard for ceramic tiles and therefore, the manufacture of porcelain-type ceramic tiles was possible using only waste and the fast-firing sintering process.

Table 28. Chemical composition (expressed wt.\% oxide), processing parameters and technological properties of ceramic materials developed from rhyolite waste.

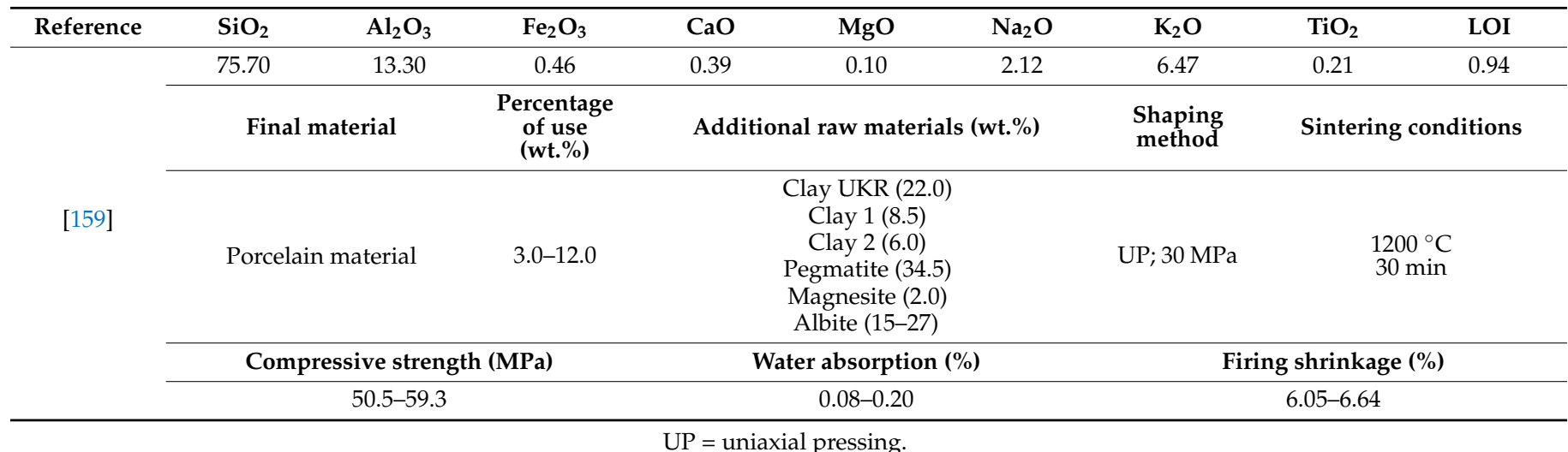

Table 29. Chemical composition (expressed wt.\% oxide), processing parameters and technological properties of ceramic materials developed from ornamental rock-cutting waste.

\begin{tabular}{|c|c|c|c|c|c|c|c|c|c|c|}
\hline Reference & $\mathrm{SiO}_{2}$ & $\mathrm{Al}_{2} \mathrm{O}_{3}$ & $\mathrm{Fe}_{2} \mathrm{O}_{3}$ & $\mathrm{CaO}$ & $\mathrm{MgO}$ & $\mathrm{Na}_{2} \mathrm{O}$ & $\mathrm{K}_{2} \mathrm{O}$ & $\mathrm{TiO}_{2}$ & $\mathrm{MnO}$ & LOI \\
\hline \multirow[t]{2}{*}[160,161]{} & 66.43 & 16.26 & 3.70 & 2.23 & 0.32 & 1.01 & 7.49 & 0.83 & 0.08 & 0.65 \\
\hline & \multicolumn{2}{|c|}{ Final material } & \multicolumn{2}{|c|}{$\begin{array}{c}\text { Percentage of use } \\
(\text { wt.\%) }\end{array}$} & \multicolumn{2}{|c|}{$\begin{array}{l}\text { Additional raw } \\
\text { materials (wt.\%) }\end{array}$} & \multicolumn{2}{|c|}{ Shaping method } & \multicolumn{2}{|c|}{ Sintering conditions } \\
\hline [160] & \multicolumn{2}{|c|}{ Aluminous porcelain } & \multicolumn{2}{|c|}{$10-35$} & $\begin{array}{r}\text { Ka } \\
\text { Plast } \\
\text { Alu } \\
\text { Felds }\end{array}$ & $\begin{array}{l}20) \\
y(25) \\
(20) \\
5-35)\end{array}$ & \multicolumn{2}{|c|}{$\mathrm{UP} ; 50 \mathrm{MPa}$} & \multicolumn{2}{|c|}{$\begin{array}{c}1000-1350^{\circ} \mathrm{C} \\
3-5^{\circ} \mathrm{C} / \mathrm{min} ; 1 \mathrm{~h}\end{array}$} \\
\hline \multirow[t]{2}{*}{ [161] } & \multicolumn{2}{|c|}{ Floor tiles } & \multicolumn{2}{|c|}{$10-47.5$} & $\begin{array}{r}\mathrm{Ka} \\
\text { Qua } \\
\text { Na-feld }\end{array}$ & $\begin{array}{l}40) \\
2.5) \\
(0-37.5)\end{array}$ & $\begin{aligned} & \text { UP } \\
& 11.50\end{aligned}$ & $\begin{array}{l}\mathrm{Pa} \\
\mathrm{mm}\end{array}$ & \multicolumn{2}{|c|}{$\begin{array}{c}1190-1250^{\circ} \mathrm{C} \\
\text { Fast-firing }\end{array}$} \\
\hline & \multicolumn{2}{|c|}{$\begin{array}{c}\text { Flexural strength } \\
(\mathrm{MPa})\end{array}$} & \multicolumn{4}{|c|}{ Water absorption (\%) } & Appar & ensity & \multicolumn{2}{|c|}{ Firing shrinkage (\%) } \\
\hline [160] & \multicolumn{2}{|c|}{$19.10-22.05$} & \multicolumn{4}{|c|}{$0.01-0.60$} & & & \multicolumn{2}{|c|}{$10.65-11.50$} \\
\hline [161] & \multicolumn{2}{|c|}{$\sim 34-67$} & \multicolumn{4}{|c|}{$0-7$} & & & \multicolumn{2}{|c|}{$5.8-9.5$} \\
\hline
\end{tabular}




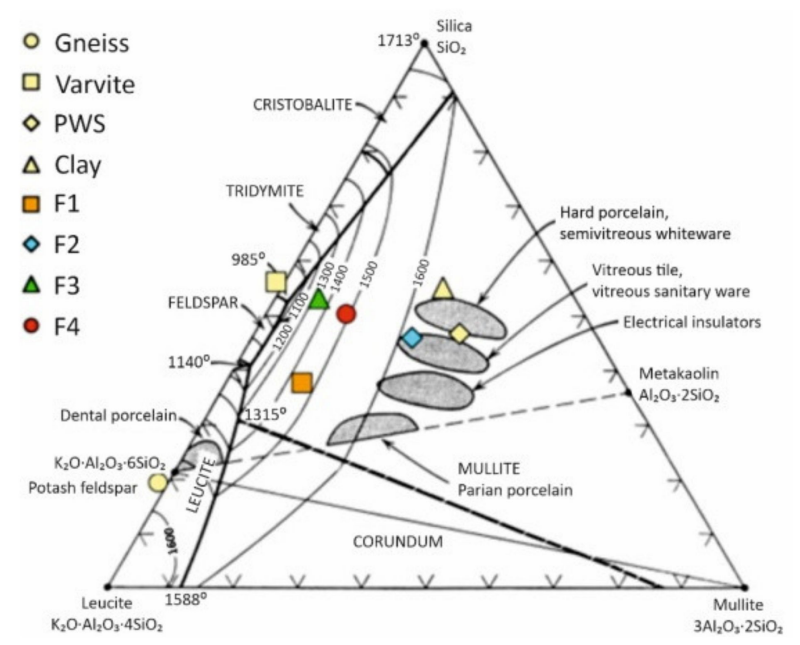

Figure 11. Leucite-silica-mullite diagram, showing typical commercial porcelain composition ranges and the location of the compositions of gneiss and varvite wastes and the formulations investigated [158].

Vieira et al. [159] investigated the manufacture of electric porcelain from the waste originated in the sawing of a gneiss rock containing $\mathrm{K}$-feldspar, microcline, albite, muscovite and quartz. The results showed that because of its mineralogical composition, with the presence of potassium feldspars and quartz, the mixture of gneiss waste with clay allowed the development of a microstructure similar to that of traditional porcelain composed of mullite, quartz and glassy phase, besides reducing the sintering temperature.

\subsubsection{Rhyolite}

Rhyolite is an extrusive igneous rock containing a high silica content, which shows a chemical structure very similar to granite, thus it is the volcanic equivalent of granite. It is primarily composed of quartz, plagioclase, and sanidine, because of the crystallization began prior to extrusion. Rhyolite also includes other minerals like hornblende and biotite.

Research conducted by Kara et al. [160] reported the manufacture of porcelain tile from three types of ball clays, pegmatite, magnesite and rhyolite reject as replacement of albite. The crystalline phases detected in the fired samples were mullite, quartz and minor amount of albite. The study proved the feasibility of the use of significant amounts of rhyolite waste (12 wt.\%) as replacement of albite in porcelain tile manufacturing as stated by the increment of $12 \%$ in both firing shrinkage and breaking strength, in relation to the reference material.

\subsubsection{Ornamental Rock-Cutting Waste}

Undefined ornamental rock sawing operation powder as an alternative raw material in the aluminous porcelain production was studied by Silva et al. [161]. Aluminous porcelains usually used for high voltage electrical insulation are formed by alumina, feldspar and kaolin and are characterized by excellent mechanical and electrical properties. Mixtures containing up to $35 \mathrm{wt} \%$ led on firing to samples composed of $\alpha$-alumina, mullite, and quartz. The technological evaluation indicated that high quality aluminous porcelains could be obtained for additions of up to $10 \mathrm{wt}$ \% of the ornamental rock waste. Water absorption ranging near zero, the tensile strength values was increased slightly and electrical resistivity was maintained with waste content.

Souza et al. [162] reported on the use of up to $47.5 \mathrm{wt}$. $\%$ of the above ornamental rock-cutting waste as gradual replacement of Na-feldspar in the manufacture of floor tiles. The results highlighted that no significant differences in the drying density of the pieces were observed when cutting waste was introduced in the body composition. Moreover, the addition of this waste produced significant effect in tile characteristic, such as decreased 
water absorption while increasing density and mechanical resistance as consequence of the development of a highly vitrified microstructure with smooth fractured surfaces.

\section{Final Remarks}

This review gives a general view of the different research studies carried out in order to valorize mining waste in the synthesis of traditional ceramic materials with mullite as a constituent crystalline phase. The increase of the global mineral demands in recent decades have resulted in the production of huge volumes of mining waste, which are generally being mismanaged by stockpiled or dumped into dams with serious effects on the environment. So it is crucial to explore new routes of management that allow its recovery and reuse. Among the different ways of recovery, their use for the production of mullite-based ceramics is an excellent alternative for mining waste, both because of their ability for integrating a high amount of waste and also to their technological properties, which turn them adequate and useful for a wide range of applications in different fields. For such purpose, an adequate design of ceramic compositions is necessary for synthesizing materials with high content of waste while simultaneously achieving appropriate technological properties (thermal, chemical and mechanical), which are closely associated with an adequate microstructure (amorphous phases, crystalline phases and porosity). However, not all clay-based ceramic compositions are suitable for the incorporation of mining waste and different criteria (particle size, flux content, etc.) determine the design of the batch compositions. Furthermore, it is necessary to control the parameters of the sintering process (temperature, heating rate and holding time) in order to ensure a material with suitable technical properties. Finally, it is necessary to point out that, although there have been several studies aimed to include different mining wastes in mullite-based ceramic materials, there are still many more to be explored, and therefore, the knowledge regarding their valorization is an important open research field that will grow in the coming years.

Author Contributions: Conceptualization, M.R.; writing—original draft preparation, M.R., I.P., M.C. and A.L.-D.; writing - review and editing, M.R., I.P. and A.L.-D. All authors have read and agreed to the published version of the manuscript.

Funding: This research received no external funding.

Institutional Review Board Statement: Not applicable.

Informed Consent Statement: Not applicable.

Data Availability Statement: Data sharing not applicable

Conflicts of Interest: The authors declare no conflict of interest.

\section{Appendix A}

Table A1 lists the name and chemical formula of minerals and crystalline phases mentioned in this review. 
Table A1. Alphabetical list of minerals and crystalline phases.

\begin{tabular}{|c|c|c|c|}
\hline Name & Chemical Formula & Name & Chemical Formula \\
\hline Albite & $\mathrm{Na}\left(\mathrm{AlSi}_{3} \mathrm{O}_{8}\right)$ & Goethite & $\mathrm{FeO}(\mathrm{OH})$ \\
\hline Alumina & $\mathrm{Al}_{2} \mathrm{O}_{3}$ & Hematite & $\mathrm{Fe}_{2} \mathrm{O}_{3}$ \\
\hline Andalusite & $\mathrm{Al}_{2} \mathrm{SiO}_{5}$ & Illite & $\left(\mathrm{K}, \mathrm{H}_{3} \mathrm{O}\right)(\mathrm{Al}, \mathrm{Mg}, \mathrm{Fe})_{2}(\mathrm{Si}, \mathrm{Al})_{4} \mathrm{O}_{10}$ \\
\hline Andesite & $(\mathrm{Ca}, \mathrm{Na}) \mathrm{Al}_{2} \mathrm{Si}_{2} \mathrm{O}_{8}$ & Kaolinite & $\mathrm{Al}_{2} \mathrm{Si}_{2} \mathrm{O}_{5}(\mathrm{OH})_{4}$ \\
\hline Anorthite & $\mathrm{CaAl}_{2} \mathrm{Si}_{2} \mathrm{O}_{8}$ & Magnesia & $\mathrm{Mg}(\mathrm{OH})_{2}$ \\
\hline Bauxite & $\mathrm{AlO}_{\mathrm{x}}(\mathrm{OH})_{3-2 \mathrm{x}}$ with $\mathrm{x}=0-1$ & Magnetite & $\mathrm{Fe}^{2+} \mathrm{Fe}^{3+}{ }_{2} \mathrm{O}_{4}$ \\
\hline Biotite & $\mathrm{K}\left(\mathrm{Mg}, \mathrm{Fe}^{2+}\right)_{6}(\mathrm{Si}, \mathrm{Al})_{8} \mathrm{O}_{20}(\mathrm{OH})_{4} \cdot \mathrm{nH}_{2} \mathrm{O}$ & Metakaolinite & $\mathrm{Al}_{2} \mathrm{Si}_{2} \mathrm{O}_{7}$ \\
\hline Boehmite & $\mathrm{AlO}(\mathrm{OH})$ & Mica & $\mathrm{KAl}_{2}\left(\mathrm{Si}_{3} \mathrm{Al}\right) \mathrm{O}_{10}(\mathrm{OH}, \mathrm{F})_{2}$ \\
\hline Borax & $\mathrm{Na}_{2} \mathrm{~B}_{4} \mathrm{O}_{5}(\mathrm{OH})_{4} \cdot 8 \mathrm{H}_{2} \mathrm{O}$ & Microcline & $\mathrm{K}\left(\mathrm{AlSi}_{3} \mathrm{O}_{8}\right)$ \\
\hline Calcite & $\mathrm{CaCO}_{3}$ & Montmorillonite & $(\mathrm{Na}, \mathrm{Ca})_{0.3}(\mathrm{Al}, \mathrm{Mg})_{2} \mathrm{Si}_{4} \mathrm{O}_{10}(\mathrm{OH})_{2} \cdot \mathrm{nH}_{2} \mathrm{O}$ \\
\hline Chlorite & $\mathrm{Na}_{0.5} \mathrm{Al}_{4} \mathrm{Mg}_{2} \mathrm{Si}_{7} \mathrm{AlO}_{18}(\mathrm{OH})_{12} \cdot 5\left(\mathrm{H}_{2} \mathrm{O}\right)$ & Mullite & $\mathrm{Al}_{4}+2 \mathrm{x} \mathrm{Si}_{2-2 \mathrm{x}} \mathrm{O}_{10-\mathrm{x}}(\mathrm{x}=0.17-0.59)$ \\
\hline Cianite & $\mathrm{Al}_{2} \mathrm{SiO}_{5}$ & Muscovite & $\mathrm{KAl}_{2}\left(\mathrm{Si}_{3} \mathrm{Al}\right) \mathrm{O}_{10}(\mathrm{OH})_{2}$ \\
\hline Clinochlore & $(\mathrm{Mg}, \mathrm{Fe})_{6}(\mathrm{Si}, \mathrm{Al})_{4} \mathrm{O}_{10}(\mathrm{OH})_{8}$ & Pirofilite & $4 \mathrm{Al}_{2} \mathrm{Si}_{4} \mathrm{O}_{11} \cdot \mathrm{H}_{2} \mathrm{O}$ \\
\hline Colemanite & $\mathrm{CaB}_{3} \mathrm{O}_{4}(\mathrm{OH})_{3} \cdot \mathrm{H}_{2} \mathrm{O}$ & Plagioclase & $(\mathrm{Na}, \mathrm{Ca})(\mathrm{Si}, \mathrm{Al})_{3} \mathrm{O}_{8}$ \\
\hline Cristobalite & $\mathrm{SiO}_{2}$ & Quartz & $\mathrm{SiO}_{2}$ \\
\hline Diaspore & $\mathrm{AlO}(\mathrm{OH})$ & Sapphirine & $\mathrm{Mg}_{4}\left(\mathrm{Mg}_{3} \mathrm{Al}_{9}\right) \mathrm{O}_{4}\left[\mathrm{Si}_{3} \mathrm{Al}_{9} \mathrm{O}_{36}\right]$ \\
\hline Dolomite & $\mathrm{CaMg}\left(\mathrm{CO}_{3}\right)_{2}$ & Sillimanite & $\mathrm{Al}_{2} \mathrm{SiO}_{5}$ \\
\hline Enstatite & $\mathrm{Mg}_{2} \mathrm{Si}_{2} \mathrm{O}_{6}$ & Spodumene & $\mathrm{LiAlSi}_{2} \mathrm{O}_{6}$ \\
\hline Feldspar & $\left(\mathrm{K}, \mathrm{Na}, \mathrm{Ca}, \mathrm{Ba}, \mathrm{NH}_{4}\right)(\mathrm{Si}, \mathrm{Al})_{4} \mathrm{O}_{8}$ & Tincalconite & $\mathrm{Na}_{2} \mathrm{~B}_{4} \mathrm{O}_{4}(\mathrm{OH})_{4} \cdot 3 \mathrm{H}_{2} \mathrm{O}$ \\
\hline Gibbsite & $\mathrm{Al}(\mathrm{OH})_{3}$ & & \\
\hline
\end{tabular}

\section{References}

1. Elshkaki, A.; Graedel, T.E.; Ciacci, L.; Reck, B. Copper demand, supply, and associated energy use to 2050. Glob. Environ. Chang. 2016, 39, 305-315. [CrossRef]

2. Evolución Anual de la Producción Mundial de Minerales de 2005 a 2018. Available online: https://es.statista.com/estadisticas/ 729104/produccion-minera-mundial/ (accessed on 2 February 2021).

3. Major Countries in Iron Ore Mine Production by Country 2015-2019. Available online: https://www.statista.com/statistics/2673 80 /iron-ore-mine-production-by-country/ (accessed on 2 February 2021).

4. Countries with the Largest Smelter Production of Aluminum from 2015 to 2019. Available online: https://www.statista.com/ statistics/264624/global-production-of-aluminum-by-country/ (accessed on 8 February 2021).

5. Major Countries in Boron Production from 2015 to 2019. Available online: https://www.statista.com/statistics/264981/majorcountries-in-boron-production/ (accessed on 2 February 2021).

6. Mine Production of Molybdenum Worlwide from 2010 to 2019. Available online: https://www.statista.com/statistics/598363 /global-mine-production-of-molybdenum/ (accessed on 2 February 2021).

7. Lithium Mine Production Worldwide from 2010 to 2018 (in Metric Tons of Lithium Content). Available online: https://www. statista.com/statistics/606684/world-production-of-lithium/ (accessed on 2 February 2021).

8. Coal Production Worldwide from 1998 to 2019 (in Exajoules). Available online: https:/ /www.statista.com/statistics/265470 /global-coal-production-in-oil-equivalent/ (accessed on 8 February 2021).

9. Brown, T.J.; Idoine, N.E.; Wrighton, C.E.; Raycraft, E.R.; Hobbs, S.F.; Shaw, R.A.; Everett, P.; Kresse, C.; Deady, E.A.; Bide, T. World Mineral Production 2014-2018, 2020th ed.; British Geological Survey: Keyworth, Nottingham, UK, 2020; ISBN 978-0-85272-788-1.

10. Amrani, M.; Taha, Y.; El Haloui, Y.; Benzaazoua, M.; Hakkou, R. Sustainable reuse of coal mine waste: Experimental and economic assessments for embankments and pavement layer applications in Morocco. Minerals 2020, 10, 851. [CrossRef]

11. Terrones-Saeta, J.M.; Suárez-Macías, J.; Linares Del Río, F.J.; Corpas-Iglesias, F.A. Study of copper leaching from mining waste in acidic media, at ambient temperature and atmospheric pressure. Minerals 2020, 10, 873. [CrossRef]

12. Tayebi-Khorami, M.; Edraki, M.; Corder, G.; Golev, A. Re-thinking mining waste through an integrative. Minerals 2019, 9, 286. [CrossRef]

13. Rankin, W.J. 16 Towards zero waste. In Minerals, Metals and Sustainability: Meeting Future Material Needs; CSIRO Publishing: Victoria, Australia, 2011; pp. 459-525. ISBN 9780643097261.

14. Rankin, W.J. Towards Zero Waste. AusIMM Bull. 2015, 2015, 32-37.

15. Vriens, B.; Plante, B.; Seigneur, N.; Jamieson, H. Mine waste rock: Insights for sustainable hydrogeochemical management. Minerals 2020, 10, 728. [CrossRef]

16. Glavic, P.; Pintaric, Z.N.; Bogataj, M. Process desing and sustainable development-A european perspective. Processes 2021, 9 , 148. [CrossRef]

17. Adiansyah, J.S.; Rosano, M.; Vink, S.; Keir, G. A framework for a sustainable approach to mine tailings management: Disposal strategies. J. Clean. Prod. 2015, 108, 1050-1062. [CrossRef] 
18. Global Tailings Portal. Available online: https://tailing.grida.no (accessed on 2 February 2001).

19. Sun, W.; Ji, B.; Khoso, S.A.; Tang, H.; Liu, R.; Wang, L.; Hu, Y. An extensive review on restoration technologies for mining tailings. Environ. Sci. Pollut. Res. 2018, 25, 33911-33925. [CrossRef] [PubMed]

20. Xu, D.M.; Zhan, C.L.; Liu, H.X.; Lin, H.Z. A critical review on environmental implications, recycling strategies, and ecological remediation for mine tailings. Environ. Sci. Pollut. Res. 2019, 26, 35657-35669. [CrossRef] [PubMed]

21. Davies, M.P. Impounded mine tailings: What are the failures telling us? Can. Min. Metall. Bull. 2001, 94, 53-59.

22. Martí, J. 20 Years Since Aznalcóllar: Lessons Learned. Available online: https://principia.es/en/20-years-since-aznalcollar/ (accessed on 22 March 2021).

23. SBS World News Australia Is Cyanide Safe to Use in Mining? Available online: https://szilviamalikgame.com/index.php/2018 /11/30/is-cyanide-safe-to-use-in-mining/ (accessed on 22 March 2021).

24. Alvés, R. Dozens Missing in Brazil Mine Disaster, Death Toll Uncertain. Available online: https://www.reuters.com/ article/us-vale-sa-bhp-billiton-dam/dozens-missing-in-brazil-mine-disaster-death-toll-uncertain-idUSKCN0SU38I20151106 (accessed on 22 March 2021).

25. Ibama Catástrofe Socioambiental Provocada Pelo Rompimento de Barragem da Mineradora Vale em Brumadinho (MG). Available online: https:/ / pt.m.wikipedia.org/wiki/Ficheiro:Brumadinho,_Minas_Gerais_(47021723582).jpg (accessed on 22 March 2021).

26. Žibret, G.; Lemiere, B.; Mendez, A.M.; Cormio, C.; Sinnett, D.; Cleall, P.; Szabo, K.; Carvalho, T. National mineral waste databases as an information source for assessing material recovery potential from mine waste, tailings and metallurgical waste. Minerals 2020, 10, 446. [CrossRef]

27. Zhu, P.; Xia, B.; Li, H.; Liu, H.; Qian, G. A novel approach to recycle waste serpentine tailing for Mg/Al layered double hydroxide used as adsorption material. Environ. Eng. Sci. 2020, 38, 99-106. [CrossRef]

28. Lu, C.; Yang, H.; Wang, J.; Tan, Q.; Fu, L. Utilization of iron tailings to prepare high-surface area mesoporous silica materials. Sci. Total Environ. 2020, 736, 139483. [CrossRef]

29. de Magalhães, L.F.; França, S.; dos Santos Oliveira, M.; Peixoto, R.A.F.; Lima Bessa, S.A.; da Silva Bezerra, A.C. Iron ore tailings as a supplementary cementitious material in the production of pigmented cements. J. Clean. Prod. 2020, 274, 123260. [CrossRef]

30. Wang, Q.; Li, J.; Zhu, X.; Yao, G.; Wu, P.; Wang, Z.; Lyu, X.; Hu, S.; Qiu, J.; Chen, P.; et al. Approach to the management of gold ore tailings via its application in cement production. J. Clean. Prod. 2020, 269, 122303. [CrossRef]

31. Saedi, A.; Jamshidi-Zanjani, A.; Darban, A.K. A review on different methods of activating tailings to improve their cementitious property as cemented paste and reusability. J. Environ. Manag. 2020, 270, 110881. [CrossRef] [PubMed]

32. Gao, S.; Cui, X.; Kang, S.; Ding, Y. Sustainable applications for utilizing molybdenum tailings in concrete. J. Clean. Prod. 2020, 266, 122020. [CrossRef]

33. Tian, X.; Xu, W.; Song, S.; Rao, F.; Xia, L. Effects of curing temperature on the compressive strength and microstructure of copper tailing-based geopolymers. Chemosphere 2020, 253, 126754. [CrossRef] [PubMed]

34. Alfonso, P.; Tomasa, O.; Domenech, L.M.; Garcia-Valles, M.; Martinez, S.; Roca, N. The use of tailings to make glass as an alternative for sustainable environmental remediation: The case of Osor, Catalonia, Spain. Minerals 2020, 10, 819. [CrossRef]

35. Behera, S.K.; Ghosh, C.N.; Mishra, K.; Mishra, D.P.; Singh, P.; Mandal, P.K.; Buragohain, J.; Sethi, M.K. Utilisation of lead-zinc mill tailings and slag as paste backfill materials. Environ. Earth Sci. 2020, 79, 389. [CrossRef]

36. Tsaousi, G.M.; Profitis, L.; Douni, I.; Chatzitheodorides, E.; Panias, D. Development of lightweight insulating building materials from perlite wastes. Mater. Constr. 2019, 69, e175. [CrossRef]

37. Conde-Vázquez, C.; De Miguel-San Martín, O.; García-Herbosa, G. Artificial arenite from wastes of natural sandstone industry. Mater. Constr. 2019, 69, e178. [CrossRef]

38. Gonzalez-Triviño, I.; Pascual-Cosp, J.; Moreno, B.; Benítez-Guerrero, M. Manufacture of ceramics with high mechanical properties from red mud and granite waste. Mater. Constr. 2019, 69, 1-8. [CrossRef]

39. Lemougna, P.N.; Yliniemi, J.; Nguyen, H.; Adesanya, E.; Tanskanen, P.; Kinnunen, P.; Roning, J.; Illikainen, M. Utilisation of glass wool waste and mine tailings in high performance building ceramics. J. Build. Eng. 2020, 31, 101383. [CrossRef]

40. Chen, Y.; Zhang, Y.; Chen, T.; Zhao, Y.; Bao, S. Preparation of eco-friendly construction bricks from hematite tailings. Constr. Build. Mater. 2011, 25, 2107-2111. [CrossRef]

41. Wang, Y.M. China recycling economy development and its mineral resources' sustainable development. Met. Mine 2005, 2, 1-3.

42. Ellen MacArthur Foundation. Towards the Circular Economy: Opportunities for the Consumer Goods Sector; Ellen MacArthur Foundation: Isle of Wight, UK, 2013; Volume 2.

43. Ellen MacArthur Foundation. Towards the Circular Economy: An Economic and Business Rationale for an Accelerated Transition; Ellen MacArthur Foundation: Isle of Wight, UK, 2013; Volume 1.

44. Sustainable Development Goals. Available online: https://www.un.org/sustainabledevelopment/development-agenda/ (accessed on 8 February 2021).

45. Mullite Mineral Data. Available online: http:// webmineral.com/data/Mullite.shtml\#.YAirmRZ7lhF (accessed on 8 February 2021).

46. Yan, K.; Guo, Y.; Liu, D.; Ma, Z.; Cheng, F. Thermal decomposition and transformation mechanism of mullite with the action of sodium carbonate. J. Solid State Chem. 2018, 265, 326-331. [CrossRef] 
47. Schneider, H.; Schreuer, J.; Hildmann, B. Structure and properties of mullite-A review. J. Eur. Ceram. Soc. 2008, 28 , 329-344. [CrossRef]

48. Santos, T.; Hennetier, L.; Costa, V.A.F.; Costa, L.C. Microwave vs conventional porcelain firing: Macroscopic properties. Int. J. Appl. Ceram. Technol. 2020, 17, 2277-2285. [CrossRef]

49. Martín-Márquez, J.; Rincón, J.M.; Romero, M. Mullite development on firing in porcelain stoneware bodies. J. Eur. Ceram. Soc. 2010, 30, 1599-1607. [CrossRef]

50. Romero, M.; Pérez, J.M. Relation between the microstructure and technological properties of porcelain stoneware. A review. Mater. Constr. 2015, 65. [CrossRef]

51. Cheraitia, A.; Redjimi, Z.; Bououdina, M. Novel mullite-cordierite ceramic refractory fabricated from halloysite and talc. Int. J. Appl. Ceram. Technol. 2021, 18, 70-80. [CrossRef]

52. Halder, K.; Roy, D.; Das, S. A comparative electrical study of nano-crystalline mullite with low dielectric loss due to incorporation of tungsten and molybdenum ion: Their uses in electronic industries. J. Mater. Sci. Mater. Electron. 2015, 26, 5803-5811. [CrossRef]

53. Shibuya, T.; Mizuno, T.; Iuchi, A.; Hasegawa, M. Formation of mullite coating by aerosol deposition and microstructural change after heat exposure. Mater. Trans. 2020, 61, 540-547. [CrossRef]

54. Kanwal, S.; Thakare, J.G.; Pandey, C.; Singh, I.; Mahapatra, M.M. Characterization of slurry-based mullite coating deposited on P91 steel welds. J. Aust. Ceram. Soc. 2019, 55, 519-528. [CrossRef]

55. Weinberg, A.V.; Goeuriot, D.; Poirier, J.; Varona, C.; Chaucherie, X. Mullite-zirconia composite for the bonding phase of refractory bricks in hazardous waste incineration rotary kiln. J. Eur. Ceram. Soc. 2021, 41, 995-1002. [CrossRef]

56. Chou, Y.S.; Canfield, N.; Bonnett, J.F.; Hardy, J.S.; Stevenson, J.W. Thermal, mechanical, and electrical properties of LSCo/mullite composite contact materials for solid oxide fuel cells. Int. J. Appl. Ceram. Technol. 2020, 17, 2051-2061. [CrossRef]

57. Andrade, R.M.; Araújo, A.J.; Alves, H.P.; Grilo, J.P.; Dutra, R.P.; Campos, L.F.; Macedo, D.A. On the physico-mechanical, electrical and dielectric properties of mullite-glass composites. Ceram. Int. 2019, 45, 18509-18517. [CrossRef]

58. Anggono, J. Mullite ceramics: Its properties structure and synthesis. Mullite Ceram. Prop. Struct. Synth. 2005, 7, 1-10. [CrossRef]

59. Krenzel, T.F.; Schreuer, J.; Laubner, D.; Cichocki, M.; Schneider, H. Thermo-mechanical properties of mullite ceramics: New data. J. Am. Ceram. Soc. 2019, 102, 416-426. [CrossRef]

60. Ilić, S.; Babić, B.; Bjelajac, A.; Stoimenov, N.; Kljajević, L.; Pošarac-Marković, M.; Matović, B. Structural and morphological characterization of iron-doped sol-gel derived mullite powders. Ceram. Int. 2020, 46, 13107-13113. [CrossRef]

61. Satoshi, S.; Contreras, C.; Juárez, H.; Aguilera, A.; Serrato, J. Homogeneous precipitation and thermal phase transformation of mullite ceramic precursor. Int. J. Inorg. Mater. 2001, 3, 625-632. [CrossRef]

62. El-Bialy, S.H.; El-Masry, M.A.A.; El-Saeed, M.A.M.; El-Kady, G.M.M. Application of taguchi methodology on the preparation of mullite precursor by hydrolysis method. Arab J. Nucl. Sci. Appl. 2017, 50, 131-135.

63. Anggono, J.; Derby, B. Pyrolysis of aluminium loaded polymethylsiloxanes: The influence of Al/PMS ratio on mullite formation. J. Mater. Sci. 2010, 45, 233-241. [CrossRef]

64. Xu, J.P.; Erickson, D.; Roy, S.; Sarin, V. Protective CVD mullite coatings on single-crystal silicon substrates. Jom 2013, 65, 567-573. [CrossRef]

65. Hossain, S.K.S.; Pyare, R.; Roy, P.K. Synthesis of in-situ mullite foam using waste rice husk ash derived sol by slip-casting route. Ceram. Int. 2020, 46, 10871-10878. [CrossRef]

66. Serra, M.F.; Conconi, M.S.; Gauna, M.R.; Suárez, G.; Aglietti, E.F.; Rendtorff, N.M. Mullite $\left(3 \mathrm{Al}_{2} \mathrm{O}_{3} \cdot 2 \mathrm{SiO} 2\right)$ ceramics obtained by reaction sintering of rice husk ash and alumina, phase evolution, sintering and microstructure. J. Asian Ceram. Soc. 2016, 4, 61-67. [CrossRef]

67. Restrepo, E.; Vargas, F.; López, E.; Baudín, C. The potential of La-containing spent catalysts from fluid catalytic cracking as feedstock of mullite based refractories. J. Eur. Ceram. Soc. 2020, 40, 6162-6170. [CrossRef]

68. Mohammadi, A.; Salehi, E.; Aghazadeh, H.; Ramezani, A.; Eidi, B. An efficient method for recycling spent residue cat-cracking catalysts (SRC) to prepare broadly-applicable mullite-based wear-resistant ceramics. Appl. Clay Sci. 2020, 187, 105488. [CrossRef]

69. Vargas, F.; Restrepo, E.; Rodríguez, J.E.; Vargas, F.; Arbeláez, L.; Caballero, P.; Arias, J.; López, E.; Latorre, G.; Duarte, G. Solid-state synthesis of mullite from spent catalysts for manufacturing refractory brick coatings. Ceram. Int. 2018, 44, 3556-3562. [CrossRef]

70. Kongkajun, N.; Cherdhirunkorn, B.; Borwornkiatkaew, W.; Chakartnarodom, P. Utilization of aluminium buffing dust as a raw material for the production of mullite. J. Met. Mater. Miner. 2019, 29, 71-75. [CrossRef]

71. Pype, J.; Michielsen, B.; Mullens, S.; Meynen, V. Impact of inorganic waste fines on structure of mullite microspheres by reaction sintering. J. Eur. Ceram. Soc. 2018, 38, 2612-2620. [CrossRef]

72. Khalil, N.M.; Algamal, Y. Recycling of ceramic wastes for the production of high performance mullite refractories. Silicon 2020, 12, 1557-1565. [CrossRef]

73. López-Cuevas, J.; Interial-Orejón, E.; Gutiérrez-Chavarría, C.A.; Rendón-Ángeles, J.C. Synthesis and characterization of cordierite, mullite and cordierite-mullite ceramic materials using coal fly ash as raw material. MRS Adv. 2017, 2, 3865-3872. [CrossRef]

74. Yugeswaran, S.; Ananthapadmanabhan, P.V.; Kobayashi, A.; Lusvarghi, L. Transferred arc plasma processed mullite from coal ash and bauxite. Ceram. Int. 2011, 37, 3437-3444. [CrossRef]

75. Guerreiro, G.G.; Vieira de Andrade, F.; Roberto de Freitas, M. Carbon nanostructures based-adsorbent obtained from iron ore tailings. Ceram. Int. 2020, 46, 29271-29281. [CrossRef] 
76. Amaral, I.B.C.; Prat, B.V.; Dos Reis, A.B. Effect of iron mining tailings as a red ceramic additive for decreased sintering temperature. Rev. Mater. 2020, 25, 1. [CrossRef]

77. Mendes Protasio, F.N.; Ribeiro de Avillez, R.; Letichevsky, S.; de Andrade Silva, F. The use of iron ore tailings obtained from the Germano dam in the production of a sustainable concrete. J. Clean. Prod. 2021, 278, 123929. [CrossRef]

78. do Carmo e Silva Defáveri, K.; dos Santos, L.F.; Franco de Carvalho, J.M.; Peixoto, R.A.F.; Brigolini, G.J. Iron ore tailing-based geopolymer containing glass wool residue: A study of mechanical and microstructural properties. Constr. Build. Mater. 2019, 220, 375-385. [CrossRef]

79. Das, S.K.; Kumar, S.; Ramachandrarao, P. Exploitation of iron ore tailing for the development of ceramic tiles. Waste Manag. 2000, 20, 725-729. [CrossRef]

80. Ghosh, I.; Mondal, A.K.; Singh, N.; Das, S.K. Evaluation of iron ore tailings for the production of building materials. Ind. Ceram. 2011, 31, 115-119.

81. Chen, Y.; Zhang, Y.; Chen, T.; Liu, T.; Huang, J. Preparation and characterization of red porcelain tiles with hematite tailings. Constr. Build. Mater. 2013, 38, 1083-1088. [CrossRef]

82. Fontes, W.C.; Franco de Carvalho, J.M.; Andrade, L.C.R.; Segadães, A.M.; Peixoto, R.A.F. Assessment of the use potential of iron ore tailings in the manufacture of ceramic tiles: From tailings-dams to "brown porcelain". Constr. Build. Mater. 2019, 206, 111-121. [CrossRef]

83. Peterson, R.; Tabereaux, A. Aluminum production. In Treatise on Process Metallurgy; Elsevier: Stockholm, Sweden, 2014; pp. 839-917; ISBN 0080969895.

84. Ayres, R.U.; Holmberg, J.; Andersson, B. Materials and the global environment: Waste mining in the 21st century. MRS Bull. 2001, 26, 477-480. [CrossRef]

85. Alumina Production Worldwide by Country 2019. Available online: https://www.statista.com/statistics/264963/global-aluminaproduction-by-country/ (accessed on 8 February 2021).

86. Khairul, M.A.; Zanganeh, J.; Moghtaderi, B. The composition, recycling and utilisation of Bayer red mud. Resour. Conserv. Recycl. 2019, 141, 483-498. [CrossRef]

87. Yao, L.; Gao, W.; Ma, X.; Fu, H. Properties analysis of asphalt binders containing Bayer red mud. J. Renew. Mater. 2020, 13, 1122. [CrossRef]

88. Zhao, Y.; Chen, P.; Wang, S.; Ji, Y.; Wang, Y.; Wu, B.; Liu, R. Utilization of Bayer red mud derived from bauxite for beliteferroaluminate cement production. J. Renew. Mater. 2020, 8, 1531-1541. [CrossRef]

89. Hu, Y.; Liang, S.; Yang, J.; Chen, Y.; Ye, N.; Ke, Y.; Tao, S.; Xiao, K.; Hu, J.; Hou, H.; et al. Role of Fe species in geopolymer synthesized from alkali-thermal pretreated Fe-rich Bayer red mud. Constr. Build. Mater. 2019, 200, 398-407. [CrossRef]

90. Xu, X.; Song, J.; Li, Y.; Wu, J.; Liu, X.; Zhang, C. The microstructure and properties of ceramic tiles from solid wastes of Bayer red muds. Constr. Build. Mater. 2019, 212, 266-274. [CrossRef]

91. Liu, S.; Guan, X.; Zhang, S.; Dou, Z.; Feng, C.; Zhang, H.; Luo, S. Sintered Bayer red mud based ceramic bricks: Microstructure evolution and alkalis immobilization mechanism. Ceram. Int. 2017, 43, 13004-13008. [CrossRef]

92. Liu, H.; Qu, Y.; Lu, Y.; Chang, Z.; Yue, Y. Structural, thermal properties and chemical durability of aluminosilicate glasses prepared by Bayer red mud. Ionics 2017, 23, 2091-2101. [CrossRef]

93. Wang, W.; Chen, W.; Liu, H.; Han, C. Recycling of waste red mud for production of ceramic floor tile with high strength and lightweight. J. Alloys Compd. 2018, 748, 876-881. [CrossRef]

94. Wang, W.; Chen, W.; Liu, H. Recycling of waste red mud for fabrication of SiC/mullite composite porous ceramics. Ceram. Int. 2019, 45, 9852-9857. [CrossRef]

95. da Silva, V.J.; da Silva, M.F.; Gonçalves, W.P.; de Menezes, R.R.; de Araújo Neves, G.; de Lucena Lira, H.; de Lima Santana, L.N. Porous mullite blocks with compositions containing kaolin and alumina waste. Ceram. Int. 2016, 42, 15471-15478. [CrossRef]

96. Global Boron Market Demand by Application in 2014 and 2015. Available online: https:/ /www.statista.com/statistics/449769 /worldwide-boron-market-demand-by-application/ (accessed on 8 February 2021).

97. Erdogmus, E. Combined effect of waste colemanite and silica fume on properties of cement mortar. Sci. Eng. Compos. Mater. 2014, 21, 369-375. [CrossRef]

98. Durgun, M.Y.; Sevinç, A.H. High temperature resistance of concretes with GGBFS, waste glass powder, and colemanite ore wastes after different cooling conditions. Constr. Build. Mater. 2019, 196, 66-81. [CrossRef]

99. Uysal, M.; Al-mashhadani, M.M.; Aygörmez, Y.; Canpolat, O. Effect of using colemanite waste and silica fume as partial replacement on the performance of metakaolin-based geopolymer mortars. Constr. Build. Mater. 2018, 176, 271-282. [CrossRef]

100. Kurama, S.; Kara, A.; Kurama, H. The effect of boron waste in phase and microstructural development of a terracotta body during firing. J. Eur. Ceram. Soc. 2006, 26, 755-760. [CrossRef]

101. Cicek, B.; Karadagli, E.; Duman, F. Valorisation of boron mining wastes in the production of wall and floor tiles. Constr. Build. Mater. 2018, 179, 232-244. [CrossRef]

102. Karadagli, E.; Cicek, B. Boron mining and enrichment waste: A promising raw material for porcelain tile production. Int. J. Appl. Ceram. Technol. 2020, 17, 563-572. [CrossRef] 
103. Mine Production of Molybdenum Worldwide in 2019, by Countries. Available online: https://www.statista.com/statistics/9108 53/global-mine-production-of-molybdenum-by-country/ (accessed on 2 February 2021).

104. Gao, S.; Zhao, G.; Guo, L.; Zhou, L.; Cui, X.; Yang, H. Mechanical properties of circular thin-tubed molybdenum tailing concrete stubs. Constr. Build. Mater. 2021, 268, 121215. [CrossRef]

105. Siddique, S.; Jang, J.G. Assessment of molybdenum mine tailings as filler in cement mortar. J. Build. Eng. 2020, 31 , 101322. [CrossRef]

106. Karhu, M.; Lagerbom, J.; Solismaa, S.; Honkanen, M.; Ismailov, A.; Räisänen, M.L.; Huttunen-Saarivirta, E.; Levänen, E.; Kivikytö-Reponen, $\mathrm{P}$. Mining tailings as raw materials for reaction-sintered aluminosilicate ceramics: Effect of mineralogical composition on microstructure and properties. Ceram. Int. 2019, 45, 4840-4848. [CrossRef]

107. Major Countries in Worldwide Lithium Mine Production from 2014 to 2019. Available online: https: / / www.statista.com/statistics / 268789/countries-with-the-largest-production-output-of-lithium/tion-output-of-lithium/ (accessed on 8 February 2021).

108. Projection of Total Worldwide Lithium Supply from 2018 to 2025. Available online: https: / www.statista.com/statistics/452010 / projected-demand-for-lithium-in-batteries-by-type-globally/ (accessed on 2 August 2020).

109. Salakjani, N.K.; Singh, P.; Nikoloski, A.N. Production of Lithium-A literature review part 1: Pretreatment of spodumene. Miner. Process. Extr. Metall. Rev. 2020, 41, 335-348. [CrossRef]

110. Salakjani, N.K.; Singh, P.; Nikoloski, A.N. Production of Lithium-A literature review. Part 2. Extraction from spodumene. Miner. Process. Extr. Metall. Rev. 2019, 1-16. [CrossRef]

111. Rioyo, J.; Tuset, S.; Grau, R. Lithium extraction from spodumene by the traditional sulfuric acid process: A review. Miner. Process. Extr. Metall. Rev. 2020, 1-10. [CrossRef]

112. Lemougna, P.N.; Yliniemi, J.; Ismailov, A.; Levanen, E.; Tanskanen, P.; Kinnunen, P.; Roning, J.; Illikainen, M. Spodumene tailings for porcelain and structural materials: Effect of temperature $\left(1050-1200{ }^{\circ} \mathrm{C}\right)$ on the sintering and properties. Miner. Eng. 2019, 141, 105843. [CrossRef]

113. Distribution of Selected Energy Carriers as a Share of Non Renewable Energy Production Worldwide from 2007 to 2018. Available online: https://www.statista.com/statistics/263232/global-production-of-non-renewable-energy-resources / (accessed on 8 February 2021).

114. Leading Hard Coal Producing Countries Worldwide in 2017 (in Million Metric Tons). Available online: https: / /www.statista. com/statistics/264775/top-10-countries-based-on-hard-coal-production/ (accessed on 8 February 2021).

115. Li, J.; Wang, J. Comprehensive utilization and environmental risks of coal gangue: A review. J. Clean. Prod. 2019, $239,117946$. [CrossRef]

116. Ashfaq, M.; Lal, M.H.; Moghal, A.A.B.; Murthy, V.R. Carbon footprint analysis of coal gangue in geotechnical engineering applications. Indian Geotech. J. 2020, 50, 646-654. [CrossRef]

117. Moghadam, M.J.; Ajalloeian, R.; Hajiannia, A. Preparation and application of alkali-activated materials based on waste glass and coal gangue: A review. Constr. Build. Mater. 2019, 221, 84-98. [CrossRef]

118. Frasson, B.J.; Pinto, R.C.A.; Rocha, J.C. Influence of different sources of coal gangue used as aluminosilicate powder on the mechanical properties and microstructure of alkali-activated cement. Mater. Constr. 2019, 69, E119-E137. [CrossRef]

119. Mohammadi, R.; Azadmehr, A.; Maghsoudi, A. Enhancing of competitive adsorptive removal of zinc and manganese from aqueous solution by iron oxide-combusted coal gangue composite. Sep. Sci. Technol. 2020, 55, 3343-3361. [CrossRef]

120. Mohammadi, R.; Azadmehr, A.; Maghsoudi, A. Fabrication of the alginate-combusted coal gangue composite for simultaneous and effective adsorption of $\mathrm{Zn}(\mathrm{II})$ and Mn(II). J. Environ. Chem. Eng. 2019, 7, 103494. [CrossRef]

121. Motesharezadeh, B.; Ahmadiyan, E.; Alikhani, H.A.; Azarnivand, H. The use of coal gangue as a cultivation bed conditioner in forage maize inoculated with arbuscular mycorrhizal fungi. Commun. Soil Sci. Plant Anal. 2017, 48, 1266-1279. [CrossRef]

122. Ji, H.; Fang, M.; Huang, Z.; Chen, K.; Xu, Y.; Liu, Y.; Huang, J. Effect of La2O3 additives on the strength and microstructure of mullite ceramics obtained from coal gangue and $\gamma$-Al2O3. Ceram. Int. 2013, 39, 6841-6846. [CrossRef]

123. Dong, W.; Bao, Q.; Gu, X.; Shen, H.; Yang, J. Dry-pressing preparation of mullite columnar structure using waste gangue during firing and its properties. J. Ceram. Soc. Jpn. 2017, 125, 75-78. [CrossRef]

124. Li, G.; Ma, H.; Tian, Y.; Wang, K.; Zhou, Y.; Wu, Y.; Zou, X.; Hao, J.; Bai, P. Feasible recycling of industrial waste coal gangue for preparation of mullite based ceramic proppant. IOP Conf. Ser. Mater. Sci. Eng. 2017, 230, 12020. [CrossRef]

125. Liu, Y.; Lian, W.; Su, W.; Luo, J.; Wang, L. Synthesis and mechanical properties of mullite ceramics with coal gangue and wastes refractory as raw materials. Int. J. Appl. Ceram. Technol. 2020, 17, 205-210. [CrossRef]

126. Pohl, W.L. Economic Geology: Principles and Practice. Metals, Minerals, Coal and Hydrocarbons-Introduction to Formation and Sustainable Exploitation of Minerals Deposits; Springer-Verlag, Ed.; Wiley-Blac.: Hoboken, NJ, USA, 2011; ISBN 978-1-4443-3663-4.

127. Murray, H.H. Applied Clay Mineralogy. Occurrences, Processing and Application of Kaolins, Bentonite, Palygorskitesepiolite, and Common Clays; Elsevier: Amsterdam, The Netherlands, 2007; Volume 2; ISBN 9780444517012.

128. Brasileiro, M.I.; Rodrigues, A.W.B.; Menezes, R.R.; Neves, G.A.; Santana, L.N.L. The Kaolin Residue and Its Use for Production of Mullite Bodies. In Sustainable Development_Energy, Engineering and Technologies_Manufacturing and Environment; Ghenai, C., Ed.; Intechopen: Rijeka, Croatia, 2012; pp. 116-142; ISBN 978-953-51-0165-9.

129. Maia, A.Á.B.; Dias, R.N.; Angélica, R.S.; Neves, R.F. Influence of an aging step on the synthesis of zeolite NaA from Brazilian Amazon kaolin waste. J. Mater. Res. Technol. 2019, 8, 2924-2929. [CrossRef] 
130. dos Santos de Castro, P.R.; Maia, A.Á.B.; Angélica, R.S. Study of the thermal stability of faujasite zeolite synthesized from kaolin waste from the Amazon. Mater. Res. 2019, 22, e20190321. [CrossRef]

131. do Rosario Pinheiro, D.; Gonçalves, L.R.; de Sena, R.L.P.; Martelli, M.C.; de Freitas Neves, R.; da Paixão Ribeiro, N.F. Industrial kaolin waste as raw material in the synthesis of the SAPO-34 molecular sieve. Mater. Res. 2020, 23, e20200043. [CrossRef]

132. de Almeida, E.P.; de Brito, I.P.; Ferreira, H.C.; Lira, H. de L.; de Lima Santana, L.N.; de Araújo Neves, G. Cordierite obtained from compositions containing kaolin waste, talc and magnesium oxide. Ceram. Int. 2018, 44, 1719-1725. [CrossRef]

133. Brasileiro, M.I.; Oliveira, D.H.S.; Lira, H.L.; de Lima Santana, L.N.; Neves, G.A.; Novaes, A.P.; Sasak, J.M. Mullite preparation from kaolin residue. Mater. Sci. Forum 2006, 530-531, 625-630. [CrossRef]

134. Brasileiro, M.I.; Menezes, R.R.; Farias, M.O.; Lira, H.L.; Neves, G.A.; Santana, L.N.L. Use of kaolin processing waste for the production of mullite bodies. Mater. Sci. Forum 2008, 591-593, 799-804. [CrossRef]

135. Menezes, R.R.; Brasileiro, M.I.; Santana, L.N.L.; Neves, G.A.; Lira, H.L.; Ferreira, H.C. Utilization of kaolin processing waste for the production of porous ceramic bodies. Waste Manag. Res. 2008, 26, 362-368. [CrossRef] [PubMed]

136. Menezes, R.R.; Brasileiro, M.I.; Gonçalves, W.P.; de Lima Santana, L.N.; Neves, G.A.; Ferreira, H.S.; Ferreira, H.C. Statistical design for recycling kaolin processing waste in the manufacturing of mullite-based ceramics. Mater. Res. 2009, 12, 201-209. [CrossRef]

137. Menezes, R.; Farias, F.; Oliveira, M.F.; de Lima Santana, L.N.; Neves, G.A.; Lira, H.L.; Ferreira, H.C. Kaolin processing waste applied in the manufacturing of ceramic tiles and mullite bodies. Waste Manag. Res. 2009, 27, 78-86. [CrossRef]

138. de Brito, I.P.; de Almeida, E.P.; de Araújo Neves, G.; de Lucena Lira, H.; Menezes, R.R.; da Silva, V.J.; de Lima Santana, L.N Development of cordierite/mullite composites using industrial wastes. Int. J. Appl. Ceram. Technol. 2021, 18, 253-261. [CrossRef]

139. Raigón-Pichardo, M.; García-Ramos, G.; Sánchez-Soto, P.J. Characterization of a waste washing solid product of mining granitic tin-bearing sands and its application as ceramic raw material. Resour. Conserv. Recycl. 1996, 17, 109-124. [CrossRef]

140. Sánchez-Soto, P.J.; Eliche-Quesada, D.; Martínez-Martínez, S.; Garzón-Garzón, E.; Pérez-Villarejo, L.; Rincón, J.M. The effect of vitreous phase on mullite and mullite-based ceramic composites from kaolin wastes as by-products of mining, sericite clays and kaolinite. Mater. Lett. 2018, 223, 154-158. [CrossRef]

141. Alves, J.O.; Junca, E.; Grillo, F.F.; Rodrigues, G.F.; Espinosa, D.C.R.; Tenório, J.A.S. Characterization of mineral wools obtained from ornamental rock wastes. REM Int. Eng. J. 2018, 71, 425-429. [CrossRef]

142. Monteiro, S.N.; Peçanha, L.A.; Vieira, C.M.F. Reformulation of roofing tiles body with addition of granite waste from sawing operations. J. Eur. Ceram. Soc. 2004, 24, 2349-2356. [CrossRef]

143. Vieira, C.M.F.; Soares, T.M.; Sánchez, R.; Monteiro, S.N. Incorporation of granite waste in red ceramics. Mater. Sci. Eng. A 2004, 373, 115-121. [CrossRef]

144. Torres, P.; Fernandes, H.R.; Agathopoulos, S.; Tulyaganov, D.U.; Ferreira, J.M.F. Incorporation of granite cutting sludge in industrial porcelain tile formulations. J. Eur. Ceram. Soc. 2004, 24, 3177-3185. [CrossRef]

145. Torres, P.; Manjate, R.S.; Quaresma, S.; Fernandes, H.R.; Ferreira, J.M.F. Development of ceramic floor tile compositions based on quartzite and granite sludges. J. Eur. Ceram. Soc. 2007, 27, 4649-4655. [CrossRef]

146. ISO 13006. Ceramic Tiles - Definitions, Classification, Characteristics and Marking; ISO: Geneva, Switzerland, 2018.

147. Pazniak, A.; Barantseva, S.; Kuzmenkova, O.; Kuznetsov, D. Effect of granitic rock wastes and basalt on microstructure and properties of porcelain stoneware. Mater. Lett. 2018, 225, 122-125. [CrossRef]

148. El-Maghraby, A.; ElMaaty, M.A.A.; Khater, G.A.; Mostafa, N.Y. Utilization of grantitoid rocks in taif area as raw materials in ceramic bodies. J. Am. Sci. 2010, 6, 799-809.

149. Acchar, W.; Ramalho, E.G.; Fonseca, Y.A.; Hotza, D.; Segadães, A.M. Using granite rejects to aid densification and improve mechanical properties of alumina bodies. J. Mater. Sci. 2005, 40, 3905-3909. [CrossRef]

150. Hernández-Crespo, M.S.; Rincón, J.M. New porcelainized stoneware materials obtained by recycling of MSW incinerator fly ashes and granite sawing residues. Ceram. Int. 2001, 27, 713-720. [CrossRef]

151. Segadães, A.M.; Carvalho, M.A.; Acchar, W. Using marble and granite rejects to enhance the processing of clay products. Appl. Clay Sci. 2005, 30, 42-52. [CrossRef]

152. Yeşilay, S.; Çak1, M.; Ergun, H. Usage of marble wastes in traditional artistic stoneware clay body. Ceram. Int. 2017, 43, 8912-8921. [CrossRef]

153. Silva, M.C.A.; Leão, V.A.; Reis, E.L. Incorporation of quartzite fines in the production of red ceramics. J. Clean. Prod. 2020, 288, 125098. [CrossRef]

154. Carreiro, M.E.A.; Santos, R.C.; Silva, V.J.; Lira, H.L.; Neves, G.A.; Menezes, R.R.; Santana, L.N.L. Resíduo de quartzito-matériaprima alternativa para uso em massas de cerâmica estrutural. Ceramica 2016, 62, 170-178. [CrossRef]

155. Silva, K.R.; Campos, L.F.A.; De Lima Santana, L.N. Use of experimental design to evaluate the effect of the incorporation of quartzite residues in ceramic mass for porcelain tile production. Mater. Res. 2018, 22, e20180388. [CrossRef]

156. De Medeiros, P.S.S.; Lira, H.D.L.; Rodriguez, M.A.; Menezes, R.R.; Neves, G.D.A.; Santana, L.N.D.L. Incorporation of quartzite waste in mixtures used to prepare sanitary ware. J. Mater. Res. Technol. 2019, 8, 2148-2156. [CrossRef]

157. Correia, S.L.; Dienstmann, G.; Folgueras, M.V.; Segadaes, A.M. Effect of quartz sand replacement by agate rejects in triaxial porcelain. J. Hazard. Mater. 2009, 163, 315-322. [CrossRef] 
158. Junkes, J.A.; Prates, P.B.; Hotza, D.; Segadães, A.M. Combining mineral and clay-based wastes to produce porcelain-like ceramics: An exploratory study. Appl. Clay Sci. 2012, 69, 50-57. [CrossRef]

159. Vieira, C.M.F.; Teixeira, S.S.; Toledo, R.; de Souza, S.D.C.; Monteiro, S.N. Electric Porcelain with ornamental rock sawing waste, Part 1: Microstructutal evolution, physical and mechanical properties. Rev. Matér. 2006, 11, 427-434.

160. Kara, A.; Kayaci, K.; Küçüker, A.S.; Bozkurt, V.; Üçbas, Y.; Özdamar, S. Use of rhyolite as flux in porcelain tile production. Ind. Ceram. 2009, 29, 71-81.

161. Silva, M.A.; Paes, H.R.; Holanda, J.N.F. Reuse of ornamental rock-cutting waste in aluminous porcelain. J. Environ. Manage. 2011, 92, 936-940. [CrossRef] [PubMed]

162. Souza, A.J.; Pinheiro, B.C.A.; Holanda, J.N.F. Processing of floor tiles bearing ornamental rock-cutting waste. J. Mater. Process. Technol. 2012, 210, 1898-1904. [CrossRef] 